\title{
Derde editie van de AOW Monitor: Effect van verhoging van de AOW-leeftijd op werk, inkomen en gezondheid
}

Citation for published version (APA):

Montizaan, R., \& Bijlsma, I. (2022). Derde editie van de AOW Monitor: Effect van verhoging van de AOWleeftijd op werk, inkomen en gezondheid. ROA. ROA Reports No. 009

https://doi.org/10.26481/umarep.2021009

Document status and date:

Published: 24/01/2022

DOI:

10.26481/umarep.2021009

Document Version:

Publisher's PDF, also known as Version of record

Please check the document version of this publication:

- A submitted manuscript is the version of the article upon submission and before peer-review. There can be important differences between the submitted version and the official published version of record.

People interested in the research are advised to contact the author for the final version of the publication, or visit the DOI to the publisher's website.

- The final author version and the galley proof are versions of the publication after peer review.

- The final published version features the final layout of the paper including the volume, issue and page numbers.

Link to publication

\footnotetext{
General rights rights.

- You may freely distribute the URL identifying the publication in the public portal. please follow below link for the End User Agreement:

www.umlib.nl/taverne-license

Take down policy

If you believe that this document breaches copyright please contact us at:

repository@maastrichtuniversity.nl

providing details and we will investigate your claim.
}

Copyright and moral rights for the publications made accessible in the public portal are retained by the authors and/or other copyright owners and it is a condition of accessing publications that users recognise and abide by the legal requirements associated with these

- Users may download and print one copy of any publication from the public portal for the purpose of private study or research.

- You may not further distribute the material or use it for any profit-making activity or commercial gain

If the publication is distributed under the terms of Article $25 \mathrm{fa}$ of the Dutch Copyright Act, indicated by the "Taverne" license above, 
Maastricht University

\section{Derde editie van de AOW Monitor: Effect van verhoging van de $A O W$-leeftijd op werk, inkomen en gezondheid}

Raymond Montizaan Ineke Bijlsma

\section{ROA Rapport}

ROA-R-2021/9

Researchcentrum voor Onderwijs en Arbeidsmarkt | ROA Research Centre for Education and the Labour Market / ROA 


\title{
Colofon
}

(c) Researchcentrum voor Onderwijs en Arbeidsmarkt (ROA). Niets uit deze uitgave mag op enige manier worden verveelvoudigd zonder voorafgaande schriftelijke toestemming van de directeur van het ROA.

\author{
Researchcentrum voor Onderwijs en Arbeidsmarkt \\ Postbus 616 \\ 6200 MD Maastricht \\ $\mathrm{T}+31433883647$ \\ secretary-roa-sbe@maastrichtuniversity.nl \\ www.roa.nl \\ School of Business and Economics \\ Maastricht University

\section{Vormgeving} \\ ROA secretariaat, Maastricht
}

ISBN: 978-90-5321-613-2

ISSN: 2666-8858

december 2021 


\section{Inhoud}

Samenvatting v v

1 Inleiding: Aanleiding, doel en onderzoeksopzet 1

1.1 Aanleiding 1

1.2 Doel 2

1.3 Onderzoeksopzet 3

1.4 Opzet rapportage

2 Wensen en mogelijkheden 7

2.1 Wensen om door te werken $\quad 7$

2.2 Mogelijkheden om door te werken $\quad 8$

3 Intermediaire effecten 11

3.1 Arbeidsmarkt en inkomen $\quad 11$

3.2 Alternatieven voor langer doorwerken: WW, ZW en WIA 16

3.3 Van WW naar werk $\quad 19$

3.4 Scholingsdeelname $\quad 20$

3.5 Investeren in belastbaarheid $\quad 22$

4 Uitkomsten voor werk, inkomen en gezondheid 25

4.1 Arbeidsmarkt en inkomen $\quad 25$

4.2 Inzetbaarheid en gezondheid 31

$\begin{array}{ll}\text { Literatuur } & 35\end{array}$

$\begin{array}{ll}\text { Appendix A: Cijfers Figuren } & 37\end{array}$

Appendix B: Difference in Difference analyses $\quad 57$

Appendix C: Gebruikte databestanden $\quad 59$

$\begin{array}{ll}\text { Appendix D: Inhoud van de monitor } & 61\end{array}$ 


\section{Samenvatting}

De AOW-leeftijd stijgt sinds 2013 stapsgewijs van 65 jaar naar 67 jaar in 2024. ROA heeft in opdracht van het Ministerie van SZW de feiten en trends die samenhangen met de AOW-leeftijdsverhoging onderzocht voor de periode 2007-2019. Het onderzoek betreft de derde editie van de AOW-monitor. De monitor is gebaseerd op een conceptueel kader dat uitgaat van een evaluatiemodel waarin diverse fasen worden onderscheiden van het proces waarop de verhoging van de AOW-leeftijd een effect heeft op de uitkomsten die relevant zijn voor het beleidsproces.

Voor de meeste datasets zijn nog geen updates beschikbaar van de cijfers die in de tweede editie van de monitor zijn gepubliceerd in april 2021, met uitzondering van cijfers over de ervaren gezondheid (GECON) en investeringen in duurzame inzetbaarheid zoals gerapporteerd door werkgevers (WEA). Voor de GECON-data geldt dat deze reeds beschikbaar zijn tot en met 2020

De derde editie van de monitor bevat echter nieuwe inzichten. Het belangrijkste verschil ten opzichte van de eerdere twee metingen is dat in de derde editie van de monitor nu voor het eerst "difference in difference" analyses zijn toegevoegd die het causale effect meten van de verhoging van de AOW-leeftijd op de arbeidsparticipatie, het hebben van een werkloosheids- en arbeidsongeschiktheidsuitkering en het inkomen. Waar voorheen de tabellen en figuren vooral correlaties toonden, kunnen wij nu deze effecten causaal identificeren.

Uit de causale analyses blijkt dat de verhoging van de AOW-leeftijd precies datgene heeft bewerkstelligd dat beleidsmakers beoogd hadden bij de invoering van dit beleidsinstrument. De arbeidsparticipatie is significant toegenomen door de verhoging van de AOW-leeftijd. Doordat de AOW-leeftijd over de tijd steeds belangrijker geworden is als norm-leeftijd om met pensioen te gaan (o.a. door afschaffing van prepensioenen), zien we dat mensen doorgaans langer in de arbeidsmarkt blijven totdat zij de verhoogde AOW-leeftijd bereikt hebben. Tegelijkertijd zien we dat mensen langer een werkloosheids- of een arbeidsongeschiktheidsuitkering ontvangen totdat zij in aanmerking komen voor AOW. Maar de trends laten ook zien dat het niet aannemelijk is dat deze uitkeringen specifiek als alternatieve routes voor vervroegde uittreding worden gebruikt. Er wordt geen toename geobserveerd in het percentage mensen die een werkloosheids- of een arbeidsongeschiktheidsuitkering ontvangen. Deze conclusies komen overeen met een eerder rapport van het CPB dat de causale effecten van de verhoging van de AOW-leeftijd tot 2017 documenteerde. ${ }^{1}$

1 Jongen, E., Rabaté, S., \& Atav, T. (2019). The effects of the increase in the retirement age in the Netherlands (No. 408. rdf). CPB Netherlands Bureau for Economic Policy Analysis. 
Daarnaast vinden we dat de AOW ook geen significant effect op de gezondheid van mensen heeft gehad. Ook vinden we met behulp van instrumentele variabele analyses (IV) geen significant causaal effect van pensionering op de gezondheid. Dit komt overeen met de bevindingen van een recent RVIM rapport dat laat zien dat de gezondheid van ouderen redelijk stabiel is en op de lange termijn zelfs nog iets kan verbeteren. ${ }^{2}$

Ten opzichte van de tweede editie van de monitor is, zoals reeds gezegd, al een update beschikbaar van de GECON-data. De update laat zien dat de gezondheid van oudere werknemers niet significant veranderd is in 2020 .

Ook de WEA-data zijn geüpdatet en zijn nu beschikbaar tot en met 2019. Uit de werkgeversanalyses op basis van deze data blijkt dat de meeste werkgevers geen speciale voorzieningen / maatregelen hebben getroffen om doorwerken te faciliteren, hoewel het percentage werkgevers dat dit niet doet wel licht dalende is. De meest populaire maatregelen weerspiegelen een klassiek ontziebeleid: er wordt vooral ingezet op extra vrije dagen voor oudere werknemers, taakverlichting en aanpassing van taken, en een kortere werkweek en werktijden. De update van de monitor laat zien dat er in 2019 minder geïnvesteerd wordt in extra vrije dagen voor ouderen (waarschijnlijk is dit CAO-bepaald), en er vooral meer wordt ingezet in op taakverlichting en aanpassing van taken. Voor deze laatste voorziening geldt dat er sprake is van bijna een verdubbeling van de inzet $(16,2 \%)$ ten opzichte van 2010 . Ook is er een voorzichtige tendens dat demotie iets vaker wordt ingezet (2,6\% in 2019) en geven werkgevers vaker aan een gezondheidsbeleid te voeren (4,1\% in 2019).

Stimuleren van scholings- en cursusdeelname wordt daarentegen niet significant vaker ingezet in 2019. Dit past bij de resultaten van de tweede editie van de monitor die liet zien dat investeringen in duurzame inzetbaarheid achterblijven en dat de scholingsdeelname is gedaald, vooral door een daling in de cursusdeelname die gefinancierd wordt door werkgevers.

2 Van der Noordt, M., van der Lucht, F., Polder, J. J., Hilderink, H. B. M., \& Plasmans, M. H. D. (2020). Gezondheid en arbeidsparticipatie rond de AOW-leeftijd: Verwachte ontwikkelingen tot 2040. 


\section{Blijven werken}

Werknemers willen iets langer doorwerken dan in 2012. Vooral de oudste groep zelfstandigen wil niet langer doorwerken en denkt dat ook niet te kunnen.
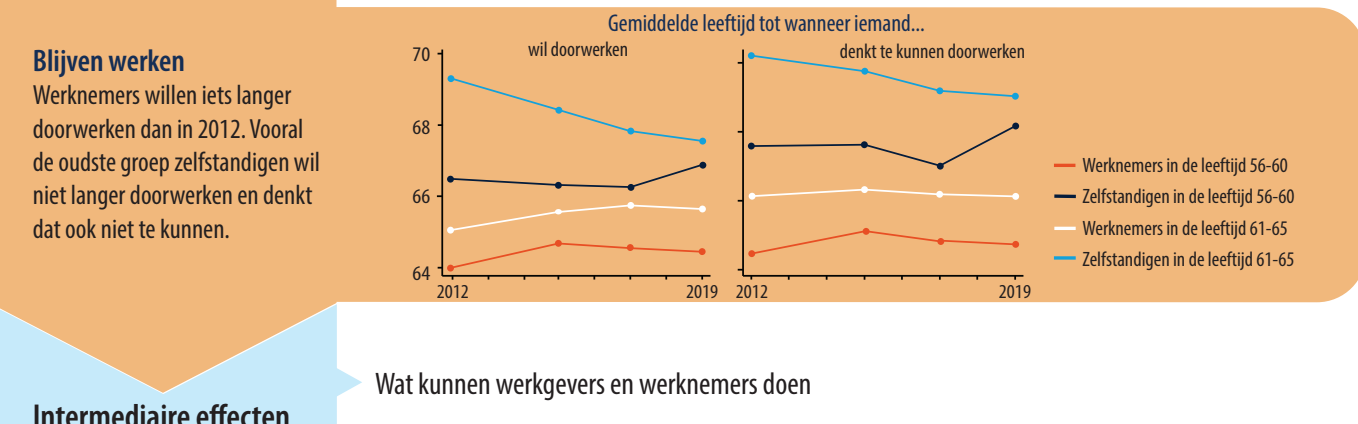

Wat kunnen werkgevers en werknemers doen

\section{Intermediaire effecten}

\section{Steeds later met pensioen}

Zowel werknemers als zelfstandigen werken steeds langer door. Vanaf 2017 is de gemiddelde pensioen leeftijd voor zelfstandigen sterk gestegen.
De piekleeftijd van pensioenen schuift steeds meer op naar de AOW-leeftijd en beweegt mee met de verhoging, vooral voor werknemers.

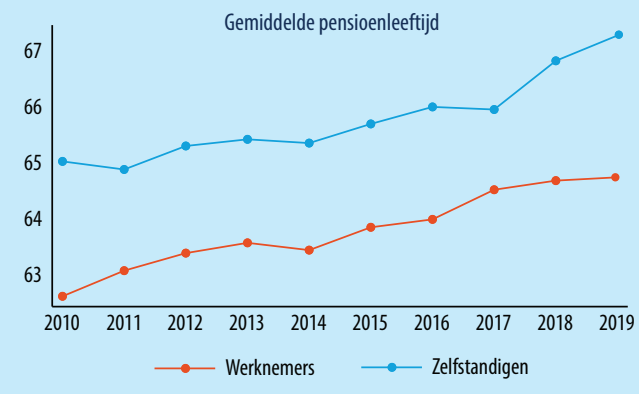

\section{Instroom en uitstroom WW/sociale zekerheid}

De uitstroomkans van werk Er is een causale impact van naar een WW-uitkering voor ouderen neemt af na een initiële stijging. Uitstroom naar een ZW / WIA-uitkering is licht gestegen.

Het percentage ouderen dat van WW instroomt naar werk neemt toe. de verhoging van de AOW-leeftijd op participatie in ZW / WIA en bijstand / WW.

Geen indicatie dat ZW/WIA en bijstand / WW wordt gebruikt als alternatieve route om vervroegd uit te treden.
Zit in de ZW/WIA (\%), naar pensioencohort Zit in de WW/Bijstand (\%), naar pensioencohort

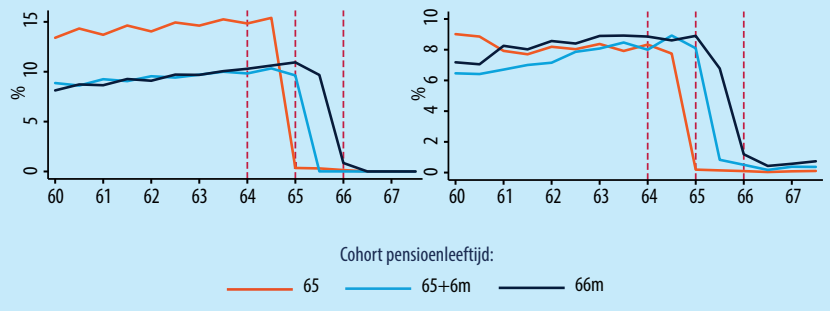

\section{Beleid gericht op langer doorwerken}

Beleid gericht op langer doorwerken is vooral een klassiek ontziebeleid.

Steeds meer aandacht voor taakverlichting en aanpassing takenpakket en een kortere werkweek / aanpassing werktijden.
Demotie wordt vaker toegepast.

Merendeel werkgevers treft geen voorzieningen / maatregelen (percentage neemt wel licht af).

\section{Inzetbaarheid - Scholing daalt}

Scholingsdeelname is sinds 2016 aanzienlijk gedaald na een initiële stijging.
De daling in scholingsdeelname komt vooral voor door minder cursussen die betaald worden door de werkgever.

\begin{tabular}{|c|c|c|c|c|c|}
\hline Voorzieningen om werknemers te laten doorwerken & 2010 & 2012 & 2014 & 2016 & 2019 \\
\hline Deeltijd vervroegde uittreding & 10 & 7,7 & 6 & 4,2 & 5,2 \\
\hline Oudere werknemers vrijstellen van onregelmatige & & & & & \\
\hline en ploegendienst & 5,5 & 5 & 5,7 & 5,6 & 6,1 \\
\hline Kortere werkweek / aanpassing werktijden & 14,6 & 15,6 & 12,3 & 14,5 & 17,4 \\
\hline Extra vrije dagen oudere werknemers & 24,1 & 22,2 & 18,8 & 20,5 & 18,6 \\
\hline Stimuleren scholings- en cursusdeelname & 6,2 & 6,9 & 6,6 & 7,1 & 7 \\
\hline Taakverbreding/taakroulatie & 4,1 & 4 & 3,6 & 4,5 & 4,2 \\
\hline Taakverlichting en of aanpassingen takenpakket & 9,8 & 10,7 & 11,8 & 15 & 16,2 \\
\hline Loopbaan en functioneringsgesprekken & 8,4 & 9 & 9,3 & 10,9 & 9,8 \\
\hline Omscholen naar andere baan / functie & 2 & 2,1 & 1,7 & 2,4 & 2,1 \\
\hline Teruggang salaris / functie & 1,9 & 1,8 & 1,8 & 1,9 & 2,6 \\
\hline Aanpassen van de werkplek & 7,5 & 8,2 & 5,6 & 6,3 & 7,2 \\
\hline Gezondheidsbeleid & 3,5 & 3,9 & 3,4 & 3,1 & 4,1 \\
\hline Er zijn geen voorzieningen / maatregelen getroffen & 63,7 & 63,2 & 60,7 & 60,4 & 58,9 \\
\hline
\end{tabular}

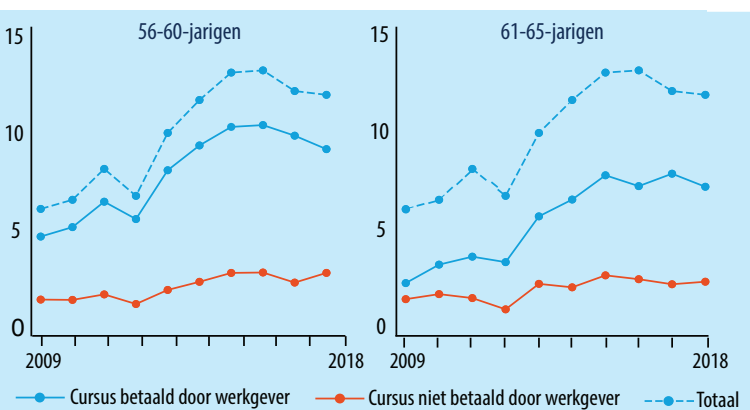




\section{AOW leidt tot een significante stijging van de arbeidsparticipatie}

AOW leidt tot een significante stijging van de arbeidsparticipatie.

De arbeidsparticipatie volgt steeds meer de norm van de AOW-leeftijd.

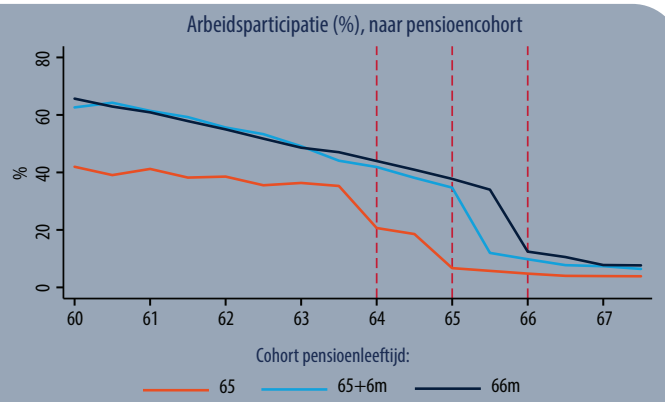

\section{Geen impact verhoging AOW-leeftijd op inkomen}

Het bruto-inkomen stijgt onafgebroken voor 64-, 65- en 66-jarigen. Stijging het grootst voor de 64-jarigen.

Er is geen significante impact van de verhoging van de AOW-leeftijd op het bruto inkomen.

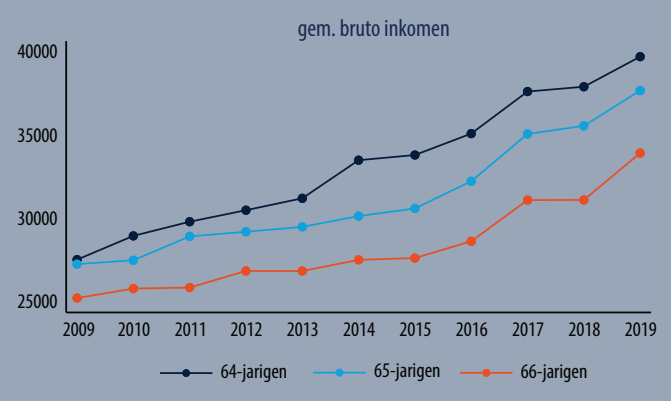

$\%$ werknemers dat makkelijk kan voldoen aan...

\section{Fysieke en psychische eisen}

Onder werknemers is geen patroon te herkennen in het aandeel dat aan de fysieke en psychische eisen van het werk kan voldoen.

Voor zelfstandigen was een negatieve trend zichtbaar die vanaf 2017 is omgeslagen.

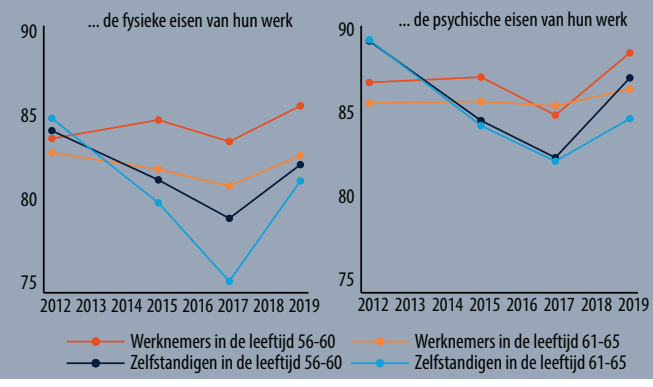

\section{Ervaren gezondheid}

De ervaren gezondheid onder ouderen blijft over het algemeen gelijk.

IV-analyses late zien dat pensioen geen significante causale impact heeft op de ervaren gezondheid.

\begin{tabular}{|l|l|}
\hline IV Resultaten & Ervaren gezondheid \\
\hline Pensioen (geïnstrumenteerd & $-0,236$ \\
\hline Cragg-Donald Wald F-stat & $79,96^{* * *}$ \\
\hline Observaties & 9.747 \\
\hline
\end{tabular}

\section{Gezonde levensjaren}

Er is sprake van een lichte toename van de gezonde levensverwachting van 65 -jarigen (in mindere mate voor mannen vergeleken met vrouwen als gevolg van verbeteringen in de gezondheidszorg en gezonde leefstijl).

Er zijn geen significante verschillen op het moment dat de AOW-leeftijd is verhoogd.

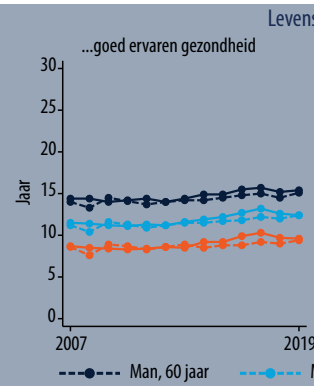

evensverwachting in...

Bron: CBS Microdata. Bewerking door ROA

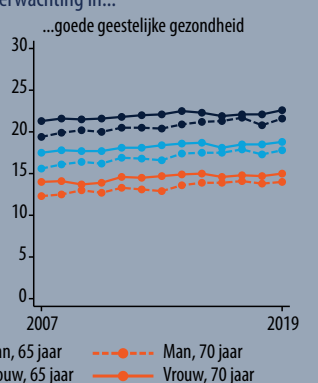

Vrouw, 65 jaar $\longrightarrow$ Vrouw, 70 jaar 


\section{Inleiding: Aanleiding, doel en onderzoeksopzet}

\subsection{Aanleiding}

Sociale zekerheid en pensioensystemen hebben belangrijke effecten op de mate waarin mensen doorwerken, hun besparingskeuzes, gezondheid en welzijn. Door de vergrijzing en ontgroening van de Nederlandse bevolking zijn er in de afgelopen decennia ingrijpende hervormingen geweest van het Nederlandse pensioenstelsel. VUT en Prepensioenen zijn afgeschaft en de AOW-leeftijd wordt verhoogd.

De AOW-leeftijd gaat sinds 1 januari 2013 stapsgewijs omhoog (zie Tabel 1). Tot 2015 steeg de AOW-leeftijd jaarlijks met 1 maand. Sinds 1 januari 2016 gebeurt dat versneld: in 2016, 2017 en 2018 waren de stappen drie maanden, en in 20194 maanden. Voor het pensioenakkoord in 2019 was de idee dat deze stappen van 4 maanden zouden worden doorgezet tot en met 2021, waarna de AOW-leeftijd vervolgens gekoppeld zou worden aan de levensverwachting. Het pensioenakkoord bracht hier verandering in met de zogenaamde Wet temporisering verhoging AOW-leeftijd. Met deze wet werd bewerkstelligd dat de AOW-leeftijd tot en met 2021 bevroren werd op 66 jaar en vier maanden. Vervolgens stijgt de AOW-leeftijd in 2022 naar 66 jaar en zeven maanden, in 2023 naar 66 jaar en tien maanden en in 2024 en 2025 naar 67 jaar. Inmiddels is de AOW-leeftijd voor de periode $2025 \mathrm{t} / \mathrm{m} 2027$ ook vastgesteld op 67 jaar. In de oude situatie steeg de AOW-leeftijd al in 2021 naar 67 jaar.

In deze rapportage analyseren wij de effecten van de stapsgewijze verhoging van de AOW-leeftijd door te onderzoeken of en in hoeverre individuen hun pensioen- en spaargedrag aanpassen en hoe het welzijn en de inzetbaarheid van werknemers die langer moeten doorwerken zich ontwikkelen. Kan en wil iedereen wel langer doorwerken? Is de stijging van de AOW-leeftijd effectief gebleken als instrument om de arbeidsparticipatie van ouderen te verhogen? En leidt de stijging van de AOW-leeftijd en pensionering tot een verslechtering of verbetering van het welzijn?

Tabel 1

Stapsgewijze verhoging van de AOW-leeftijd voor en na de invoering van de Wet temporisering verhoging AOW-leeftijd

\begin{tabular}{|c|c|c|}
\hline Jaar & AOW-leeftijd voor pensioenakkoord in 2019 & AOW-leeftijd na pensioenakkoord in 2019 \\
\hline 2013 & $65+1$ maand & \\
\hline 2014 & $65+2$ maanden & \\
\hline 2015 & $65+3$ maanden & \\
\hline 2016 & $65+6$ maanden & \\
\hline 2017 & $65+9$ maanden & \\
\hline 2018 & 66 & \\
\hline
\end{tabular}




\begin{tabular}{|c|c|c|}
\hline 2019 & $66+4$ maanden & $66+4$ maanden \\
\hline 2020 & $66+8$ maanden & $66+4$ maanden \\
\hline 2021 & 67 & $66+4$ maanden \\
\hline 2022 & $67+3$ maanden & $66+7$ maanden \\
\hline 2023 & $67+3$ maanden & $66+10$ maanden \\
\hline 2024 & $67+3$ maanden & 67 \\
\hline 2025 & $67+3$ maanden & 67 \\
\hline
\end{tabular}

\subsection{Doel}

Om deze vragen te beantwoorden heeft het Ministerie van Sociale Zaken en Werkgelegenheid in 2019 een eerste onderzoek laten uitvoeren naar de effecten van de verhoging van de AOW-leeftijd. ${ }^{3}$ Het Ministerie van Sociale Zaken en Werkgelegenheid wil naar aanleiding van de in 2019 uitgevoerde beleidsdoorlichting van artikel 8 Oudedagsvoorziening van de SZW begroting deze monitor voortzetten door de feiten en trends die samenhangen met de AOW-leeftijdsverhoging en het langer doorwerken de komende vijf jaar jaarlijks in beeld te brengen. Doel is om de ontwikkelingen in arbeidsmarkt, inkomen, inzetbaarheid en gezondheid van 55-75- jarigen periodiek in kaart te brengen. In april 2021 is de tweede editie van de monitor gepubliceerd. ${ }^{4,5}$

In deze rapportage worden de resultaten besproken van de analyses van de derde editie van de AOW-monitor. In de monitor wordt de periode 2007-2019 in beeld gebracht voor de groep 55-75-jarigen die op 31 december van elk jaar in Nederland wonen. ${ }^{6}$ Daarbij kijken we ook naar in welke mate inkomen, opleidingsniveau en geslacht van invloed is op hoe mensen reageren op de verhoging van de AOW-leeftijd.

Hoewel voor de meeste datasets nog geen updates beschikbaar zijn van de cijfers die in de tweede editie van de monitor zijn gepubliceerd, met uitzondering van de ervaren gezondheid (GECON) en de investeringen in duurzame inzetbaarheid zoals gerapporteerd door werkgevers (WEA), bevat de derde editie van de monitor nieuwe inzichten. Het belangrijkste verschil ten opzichte van de eerdere twee metingen is dat in de derde versie van de monitor nu voor het eerst "difference in difference" analyses zijn toegevoegd die het causale effect meten van de verhoging van de AOW-leeftijd op de arbeidsparticipatie, en het hebben van een werkloosheids- en arbeidsongeschiktheids-

3 Het rapport is in 2020 verschenen: Ministerie van Sociale Zaken en Werkgelegenheid / SEO. (2020) Effect verhoging AOW-leeftijd. Resultaten monitor-en literatuuronderzoek-Rapport-Kennisplatform Werk en Inkomen.

4 Montizaan, R., Goedhart, R., \& Bijlsma, I. (2021). AOW Monitor 2021: Effect van verhoging van de AOW-leeftijd op werk, inkomen en gezondheid. ROA. ROA Reports No. 002 https://doi.org/10.26481/umarep.2021002

5 De tweede editie is verlaat uitgevoerd. De derde editie van de AOW-monitor houdt vast aan de oorspronkelijke planning. Voor de meeste datasets zijn nog geen updates beschikbaar van de cijfers die zijn gepubliceerd in de tweede editie van de monitor.

6 Ervaren gezondheid wordt tot en met 2020 in beeld gebracht. 
uitkering. Waar voorheen de tabellen en figuren vooral correlaties toonden, kunnen wij nu deze effecten precies causaal identificeren.

We concentreren ons bij deze causale analyses voornamelijk op de intermediaire effecten en uitkomsten: de arbeidsparticipatie, pensioengedrag, het hebben van een werkloosheids- en arbeidsongeschiktheidsuitkering, en het welzijn van mensen.?

\subsection{Onderzoeksopzet}

Het conceptueel kader dat ten grondslag ligt aan de monitor wordt weergegeven in Figuur 1. Het kader gaat uit van een evaluatiemodel waarin meerdere fasen worden onderscheiden van het proces waarop de verhoging van de AOW-leeftijd een effect kan hebben op relevante beleidsuitkomsten. Kort samengevat beschrijft het model dat de interventie (verhoging AOW-leeftijd) leidt tot prikkels onder werknemers en werkgevers om hun gedrag aan te passen. Het proces van deze aanpassing hangt af van de wensen en mogelijkheden om langer door te werken. Uiteindelijk leidt de gedragsveranderingen tot intermediaire effecten en beleidsuitkomsten. Zie Tekst box 1 voor een meer uitgebreide beschrijving van het conceptueel kader.

\section{Tekst box 1}

Uitleg beleidstheorie van instrument tot maatschappelijk effect

Beschrijving fases waarmee de verhoging AOW-leeftijd een impact heeft op de beleidspraktijk

1. Eerste fase: De verhoging van de AOW-leeftijd geeft werkenden een extra financiële prikkel om door te werken omdat zij pas later AOW ontvangen. Ook werkgevers ondervinden een prikkel omdat hun werknemers langer in dienst zullen blijven doordat de arbeidscontracten voor onbepaalde tijd veelal automatisch doorlopen tot de AOW-leeftijd.

2. Fase 2: Door deze prikkels zullen zowel werknemers als werkgevers hun wensenmoeten aanpassen aan de nieuwe situatie. Accepteren werknemers lager pensioen, gaan ze bijsparen of werken ze langer door? En laten werkgevers langer doorwerken toe? Het proces waarop deze voorkeuren veranderen hangt ook af van de mogelijkheden die zij hebben. De prikkel voor werkenden en werkgevers om langer door te werken werkt uitsluitend effectief als werkenden ook in staat zijn om door te werken en ook de motivatie hebben om aan de slag te blijven.

$7 \quad$ Voor de overige variabelen zoals de wensen en mogelijkheden om door te werken, of trainingsmogelijkheden worden geen causale analyses uitgevoerd. Deze wensen en mogelijkheden worden uitsluitend voor werkenden geanalyseerd, en geven een vertekend beeld. 
Dit wordt enerzijds beïnvloed door de belastbaarheid en inzetbaarheid van het individu, maar ook door de belasting van het werk.

3. Fase 3: In deze fase zetten werknemers en werkgevers hun wensen, gegeven de mogelijkheden die zij ervaren, om in gedrag (intermediaire effecten). Degenen die willen doorwerken zullen gedurende hun loopbaan bijvoorbeeld meer kunnen gaan investeren in het vergroten van hun belastbaarheid en inzetbaarheid, bijvoorbeeld door het volgen van scholing. Daarnaast is het mogelijk dat werknemers die niet langer willen doorwerken ervoor kiezen om meer te gaan (bij)sparen voor hun pensioen. En de mogelijkheid bestaat dat werknemers alternatieve routes opzoeken om alsnog vervroegd uit te treden.

4. De vierde fase omvat uiteindelijk de beleidsuitkomsten. Het uiteindelijke doel van de verhoging van de AOW-leeftijd is om de arbeidsparticipatie van ouderen te vergroten. De AOW-lasten zullen dan gaan dalen. Tegelijkertijd zijn er neveneffecten mogelijk zoals een hoger beroep op WW/WIA en bijstand, en potentiële inkomenseffecten.

\subsection{Opzet rapportage}

Het rapport volgt de structuur van het conceptueel kader in figuur 1. Hoofdstuk 2 bespreekt de trends in de wensen en mogelijkheden die werknemers hebben om langer door te werken. Hoofdstuk 3 laat de trends zien in de intermediaire effecten en hoofdstuk 4 bespreekt de uitkomstmaten. Gedetailleerde informatie over de monitor en verdere achtergrondinformatie zijn opgenomen in de bijlagen. 


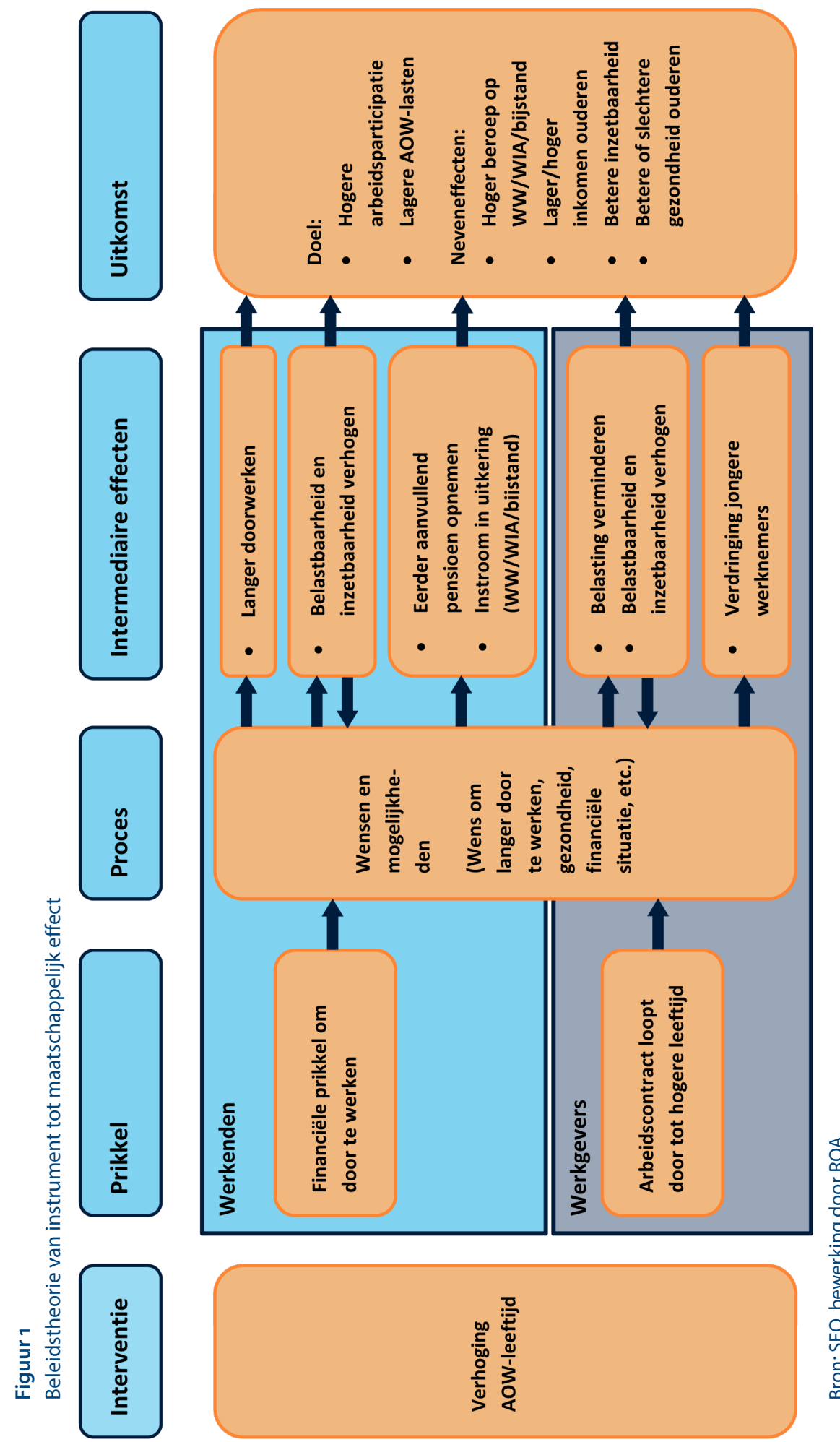

Inleiding: Aanleiding, doel en onderzoeksopzet 5 



\section{Wensen en mogelijkheden}

De effectiviteit van de financiële prikkel die de verhoging van de AOW-leeftijd heeft op de arbeidsparticipatie is sterk afhankelijk van de wensen die werknemers hebben ten aanzien van hun pensioen. De mate waarin werknemers daadwerkelijk bereid zijn om door te werken, en hiertoe ook in staat zijn, zijn immers belangrijke voorwaarden voor het verhogen van de arbeidsparticipatie.

In dit hoofdstuk worden de ontwikkelingen rondom deze wensen en mogelijkheden besproken. De data hiervoor zijn beschikbaar tot en met 2019.

\subsection{Wensen om door te werken}

\section{Trends in de data}

Figuur 2 laat de trend zien in hoe werknemers de volgende vraag hebben beantwoord: 'Tot welke leeftijd wilt u doorgaan met werken?'. Daarbij wordt onderscheid gemaakt tussen werknemers en zelfstandigen en twee leeftijdsgroepen ( 55 tot en met 60 jaar en 61 tot en met 65 jaar).

De figuur laat zien dat de wens om door te werken licht gestegen is tot 2019 onder werknemers in de leeftijdsklasse 61 tot 65 jaar. In de leeftijdsklasse 56 tot 60 jaar is de gewenste uittreedleeftijd echter licht gedaald nadat deze in 2015 fors was gestegen. De wensen voor de 61-en 65-jarigen lopen dus grotendeels in de pas met de verhoging van de AOW-leeftijd.

Voor zelfstandigen in de leeftijdscategorie 61-65 jaar is de wens om door te werken echter afgenomen. Hoewel 61-65-jarige zelfstandigen in 2012 gemiddeld genomen nog bereid waren om tot hun 69ste door te werken, willen zij nu echter doorwerken tot 67-jarige leeftijd. De gewenste uittredeleeftijd van zelfstandigen in de leeftijdscategorie 56-60 jaar is echter sinds 2017 licht gestegen. De figuur laat verder zien dat het verschil in wensen tussen zelfstandigen en werknemers minder groot geworden is over het verloop van de tijd. ${ }^{8}$

8 Tabel A1 laat verder zien dat er geen verschillen zijn in de wensen voor doorwerken tussen lager, middelbaar en hoger opgeleide werknemers. Wel valt er een verschil te observeren bij de zelfstandigen wat betreft het opleidingsniveau. Des te hoger het opleidingsniveau, des te langer een zelfstandige wil doorwerken. De daling in de gewenste uittreedleeftijd onder 61-65-jarigen was het sterkst onder de zelfstandigen met een middelbaar opleidingsniveau. 


\section{Figuur 2}

Ouderen willen in 2019 niet veel langer doorwerken dan in 2012 en denken dat ook niet te kunnen* (leeftijd in jaren)

\section{Gemiddelde leeftijd tot wanneer iemand...}
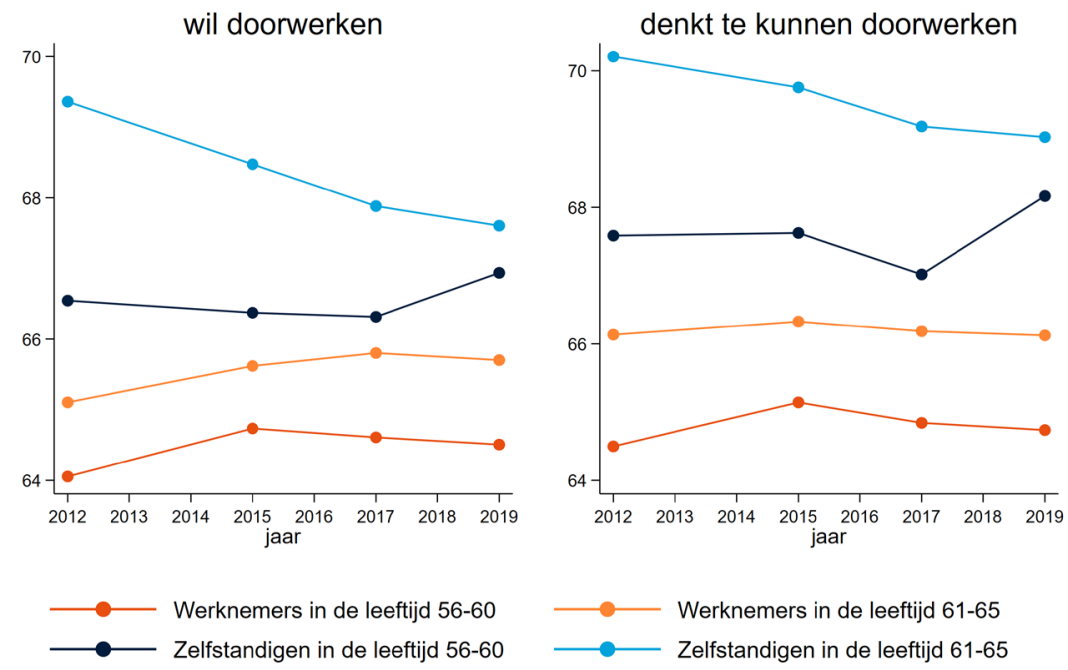

Bron: CBS Microdata. Bewerking door ROA

* Ten opzichte van de tweede editie van de monitor is er nog geen update beschikbaar

\subsection{Mogelijkheden om door te werken}

\section{Trends in de data}

De rechterhelft van Figuur 2 laat voor werknemers zien tot welke leeftijd zij denken te kunnen werken. De gemiddelde leeftijd tot wanneer werknemers verwachten door te kunnen werken is vrij constant gebleven. Dit duidt erop dat de inzetbaarheid van werknemers dus niet of weinig veranderd is sinds 2012 .

Onder de zelfstandigen vinden we daarentegen een negatieve trend voor de zelfstandigen in de leeftijdscategorie 61-65 jaar. Men verwacht in 2019 ruim een jaar minder lang door te kunnen werken dan in 2012. Zelfstandigen in de leeftijdscategorie 56-60 jaar zijn sinds 2017 juist optimistischer geworden en denken een jaar langer door te werken. ${ }^{9}$

Gemiddeld genomen blijkt dus dat de wensen en mogelijkheden onder werknemers vrij constant zijn gebleven en zij in beperkte mate meer wensen en mogelijkheden zien

9 Uit Tabel A1 blijkt verder dat hoogopgeleiden een jaar langer denken te kunnen doorwerken dan laagopgeleiden en dat dit verschil over de tijd niet verandert. De sterke daling onder zelfstandigen in de leeftijdscategorie 61-65 jaar komt vooral doordat laagopgeleide zelfstandigen verwachten minder lang te kunnen doorwerken (van 69,5 naar 66,3 jaar). 
om door te werken. Onder zelfstandigen is het beeld niet eenduidig, aangezien de trend negatief is voor de oudste leeftijdscategorie, terwijl deze positief is voor de jongere leeftijdscategorie. 



\section{Intermediaire effecten}

Dit hoofdstuk gaat in op de intermediaire effecten van de verhoging van de AOW-leeftijd. Het hoofdstuk beantwoordt de vraag of werknemers later met pensioen gaan, in hoeverre hun uitstroomkans naar de Ziektewet en/of WIA, of de WW/bijstand is toegenomen als gevolg van de verhoging van de AOW-leeftijd en de mate waarin zij meer cursussen zijn gaan volgen. Ook wordt onderzocht om werkgevers maatregelen treffen om doorwerken te stimuleren.

Deze acties (oftewel intermediaire effecten) zijn allemaal onderdeel van het proces die de effectiviteit bepaalt van het effect van de verhoging van de AOW-leeftijd op de arbeidsparticipatie van ouderen en de AOW-lasten voor de samenleving.

\subsection{Arbeidsmarkt en inkomen}

Zijn werknemers als gevolg van de AOW-leeftijd later met pensioen gegaan? Hieronder worden de trends getoond tot en met 2019.

\section{Trends in de data}

Zowel werknemers als zelfstandigen zijn langer door gaan werken na 2010. Tot 2017 was de toename in de gemiddelde pensioenleeftijd groter voor werknemers dan voor zelfstandigen. De afschaffing van het prepensioen voor werknemers in 2006 heeft ervoor gezorgd dat in de opvolgende jaren de gemiddelde pensioenleeftijd voor werknemers fors is gestegen. Het gevolg hiervan is dat er een verschil is ontstaan in de toename van de gemiddelde pensioenleeftijd tussen werknemers en zelfstandigen. Tussen 2010 en 2012 is de gemiddelde pensioenleeftijd voor werknemers met 1 jaar gestegen. Sinds 2012 stijgt de gemiddelde pensioenleeftijd van werknemers en werkgevers verder. Dit kan onder andere komen doordat zowel werknemers als zelfstandigen te maken hebben gekregen met de stapsgewijze verhoging van de AOW-leeftijd. Echter, ook de effecten van de eerdere hervormingen, zoals de afschaffing van prepensioen zijn hier deels nog voor verantwoordelijk. In 2017 bedroeg de gemiddelde pensioenleeftijd 64,5 jaar voor werknemers en 66 jaar voor zelfstandigen.

Van 2017 tot 2019 is de gemiddelde pensioenleeftijd sterk toegenomen voor zelfstandigen: binnen twee jaar tijd stijgt de gemiddelde leeftijd met bijna 16 maanden, naar 
67,3 jaar. Voor werknemers is er daarentegen een vertraging waarneembaar in de stijging van de gemiddelde pensioenleeftijd. ${ }^{10}$

\section{Figuur 3}

De gemiddelde pensioenleeftijd stijgt* (pensioenleeftijd in jaren)

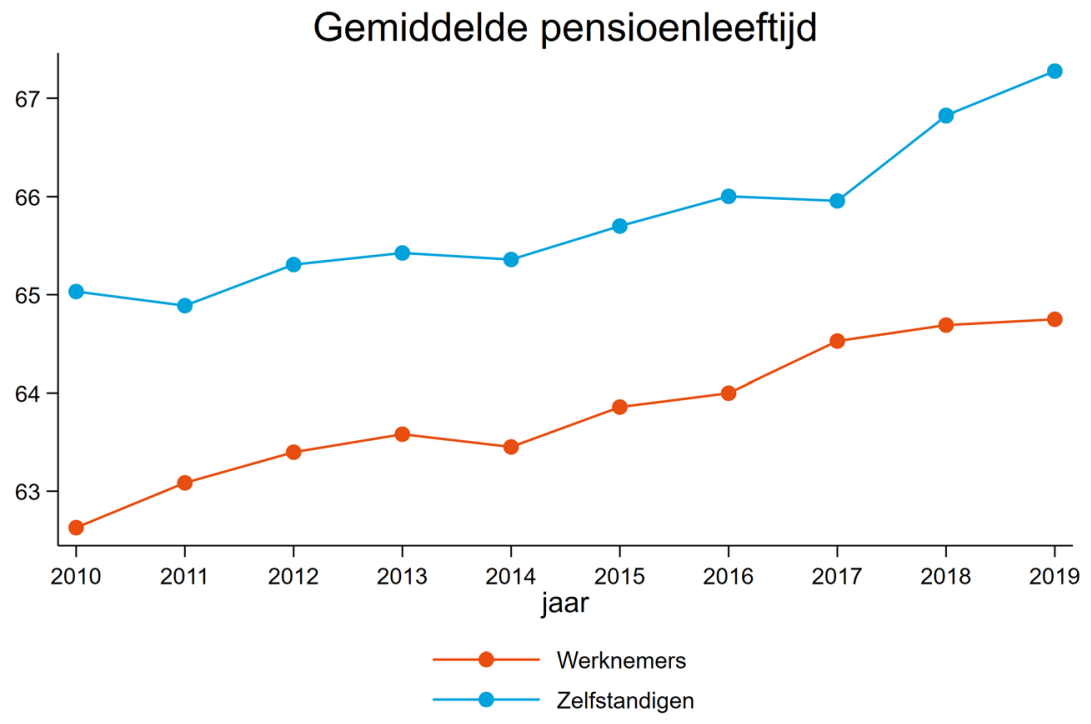

Bron: CBS Microdata. Bewerking door ROA

* Ten opzichte van de tweede editie van de monitor is er nog geen update beschikbaar

\section{Causale analyse}

De vraag is nu in welke mate de verhoging van de AOW-leeftijd een impact heeft gehad op deze stijging in de pensioenleeftijd. Om dit te meten hebben we "difference in difference" analyses geschat. Difference in Difference (DiD) is een quasi experimentele techniek die het differentiële effect meet van een interventie op een 'interventiegroep' versus een 'controlegroep' in een natuurlijk experiment." Op basis van paneldata bere-

10 Figuur A1 in Appendix A laat verder zien dat de gemiddelde pensioenleeftijd voor alle inkomensklassen geleidelijk is gestegen. Ouderen uit lagere inkomensklassen gaan later met pensioen. Dit geldt vooral voor werknemers, waarvoor in 2019 ruim één jaar verschil zit in de gemiddelde pensioenleeftijd tussen de laagste inkomensklasse (tot minimumloon, gemiddeld 64,8 jaar) en de hoogste inkomensklasse (boven 2 keer modaal, gemiddeld 63,8 jaar). De sterke toename van de gemiddelde pensioenleeftijd van zelfstandigen tussen 2010 en 2019 valt niet toe te schrijven aan een forsere toename van bijvoorbeeld lagere inkomensklassen op de arbeidsmarkt. Zelfstandigen in alle inkomensklassen zagen in deze periode een toename van ongeveer 2,5 jaar in de gemiddelde pensioenleeftijd. Het is dus ook onwaarschijnlijk dat de forse toename in de gemiddelde pensioenleeftijd onder zelfstandigen de laatste paar jaar werd gedreven door een toename van zzp'ers op de arbeidsmarkt.

11 Zie Appendix B voor een uitgebreide beschrijving van de methodiek die is toegepast. Zo blijkt uit de Appendix dat doormiddel van tijdsdummies wordt gecorrigeerd voor conjunctuureffecten. Zie de studie van De Grip, A., Künn, A., \& Montizaan, R. (2019). Raamwerk Evaluatie Interventies Leven Lang Ontwikkelen. ROA. ROA Reports No. 002 https://doi.org/10.26481/umarep.2019002 voor een uitgebreid overzicht van de voordelen van $\mathrm{DiD}$ om causale effecten te meten, en de voorwaarden waaraan voldoen moet worden om te komen tot betrouwbare schattingen. 
kent de DiD-methode het effect van een interventie op een uitkomst door te kijken of de uitkomstmaat voor de interventiegroep zich (gemiddeld) anders ontwikkelt na de interventie dan voor de controlegroep.

In dit geval bestaan de interventiegroepen uit de cohorten werknemers die op latere leeftijden met AOW kunnen (in totaal hebben we 7 interventiegroepen). De controlegroep is het cohort dat voor het laatst op 65-jarige leeftijd AOW kreeg. De DiD methode vergelijkt vervolgens in welke mate de pensioenleeftijd zich anders is gaan ontwikkelen van de interventiegroepen nadat werknemers getroffen worden door de verhoging van de AOW-leeftijd. Relevant hierbij om op te merken is dat de methode niet probeert te meten of cohorten van elkaar verschillen. De methode laat verschillen tussen cohorten toe, zolang de trends voor de interventie ongeveer parallel verliepen voor de interventie (cohorten kunnen verschillen door onder andere de toegenomen arbeidsparticipatie onder vrouwen, de invloed van het middelloonstelsel in het pensioensysteem, etc). De identificatie van het causale effect zit hem vooral of er sterke veranderingen in de trends waarneembaar zijn direct na de verhoging van de AOW-leeftijd, waardoor de verschillen tussen de interventiegroep en de controlegroep groter worden.

We passen dezelfde methode toe als in de studies van Staubli en Zweimuller (2013), CPB (2019) en Ardito (2021) die eveneens onderzoek deden naar de impact van graduele verhogingen van de pensioenleeftijd voor Nederland, Oostenrijk en Italië.

Figuur 4 laat de voorspelde waarden zien van de DiD analyse. Voor presentatiedoeleinden laten we niet de resultaten zien van alle interventiegroepen, maar uitsluitend van de controlegroep (cohort dat op 65-jarige leeftijd AOW krijgt), en twee interventiegroepen (de cohorten die op 65, en 6 maanden en 66 jaar AOW krijgen).

Duidelijk blijkt uit de figuur dat het percentage mensen die met pensioen zijn tot 62 jaar en 6 maanden nog ongeveer parallel verloopt. Mensen in de controlegroep zijn al wel iets vaker met pensioen als gevolg van dat zij minder sterk zijn getroffen door andere hervormingen in het pensioenstelsel (o.a. de invoering van het middelloonstelsel). Vanaf 63-jarige leeftijd zien we daarentegen we een stijging van het percentage mensen dat met pensioen is van ongeveer $20 \%$ tot ongeveer $50 \%$. De oorzaak hiervoor is dat de controlegroep ook nog aanspraak kon maken op prepensioenregelingen waarvoor de normleeftijd rond 63 jaar lag. Pas op 65-jarige leeftijd gaat de rest van de controlegroep met pensioen. Dus ongeveer $50 \%$ van de mensen in de controlegroep koos de AOW-leeftijd als pensioendatum. Voor de interventiegroepen observeren wij drie belangrijke veranderingen in de trends. Allereerst, als gevolg dat jongere cohorten geen recht meer hadden op prepensioen, verloopt de trend na 63 jaar veel vlakker voor de interventiegroepen. Ten tweede, duidelijk is zichtbaar dat de interventiegroepen hun pensioendatum als gevolg van de pensioenleeftijd hebben uitgesteld. Waar ongeveer $50 \%$ van de mensen in de controlegroep koos om met pensioen te gaan op 65-jarige leeftijd, is deze piek nu met een half jaar verschoven tot 65 jaar en 6 maanden voor de eerste interventiegroep en met een jaar voor degenen die pas AOW krijgen op 66-jarige leeftijd. Ten derde, de piek rondom de AOW-leeftijd is iets sterker geworden (60\% voor degenen die pas AOW krijgen op 66-jarige leeftijd). Deze drie veranderingen in de 
trends kunnen als het causale effect van de verhoging van de AOW-gerechtigde leeftijd worden geïnterpreteerd. ${ }^{12}$

\section{Figuur 4}

DiD resultaten voor pensioen, naar pensioencohort (\% van populatie)

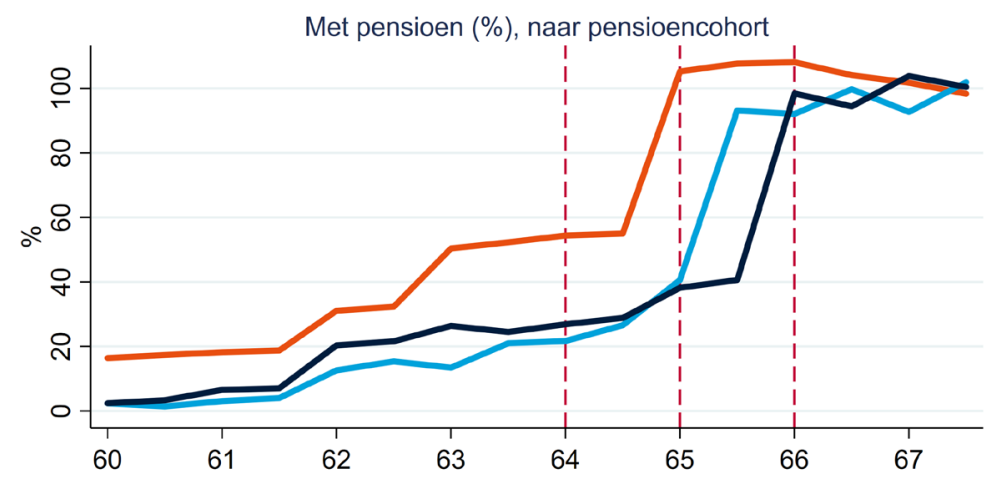

Cohort pensioenleeftijd:

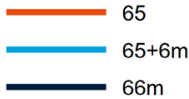

De causale effecten van de DiD worden ook ondersteund door observaties in de frequenties van de pensioenleeftijden. Hierdoor wordt zichtbaar op welke leeftijden de meeste mensen met pensioen gaan, oftewel wat de 'piekleeftijden' zijn. Figuur 5 laat de dichtheid van de frequenties zien voor pensioenleeftijden van zowel werknemers als zelfstandigen. In 2010 en de paar opvolgende jaren is de frequentie van pensioenleeftijden voor werknemers nog breed verdeeld tussen 61 en 65 jaar. Hierna is sprake van een verschuiving van de piekleeftijd naar 65 jaar: deze leeftijd heeft tot en met 2016 de hoogste dichtheid. Mensen die geen recht hadden op prepensioen hebben dus vooral de AOW-leeftijd als de nieuwe norm genomen voor hun pensioen. Pensioen na 65 jaar komt relatief weinig voor tot 2016. 2016 en 2017 zijn belangrijke jaren wat de piekleeftijden van het pensioen betreft, voor zowel werknemers als zelfstandigen. Tussen deze jaren slaat de piekleeftijd voor beide groepen om van 65 naar 66 jaar. De piek op 66 jaar is vervolgens in 2018 en 2019 steeds duidelijker zichtbaar. Voor werknemers geldt dat zij nauwelijks doorwerken voorbij 66 jaar. Voor zelfstandigen zien we in 2019 al dat de piek op 66 jaar iets minder sterk is en worden de eerste tekenen van een omslag van de piekleeftijd naar 67 jaar al zichtbaar.

Samenvattend kan worden gesteld dat de pensioenleeftijd dus een causale impact heeft gehad op de pensioenleeftijd en dat de pensioenleeftijd steeds meer is opgeschoven naar de AOW-leeftijd, waardoor het causale effect van de verhoging van de AOW-leeftijd op pensioengedrag nog is versterkt.

12 We hebben ook separate analyses gedaan voor zelfstandigen en werknemers. Er zijn geen grote verschillen in het effect van de AOW-leeftijd op pensioengedrag, behalve dat de effecten iets kleiner zijn voor de zelfstandigen omdat er een groep is die iets langer doorwerkt. 
Figuur 5

Piekleeftijden in pensionering*
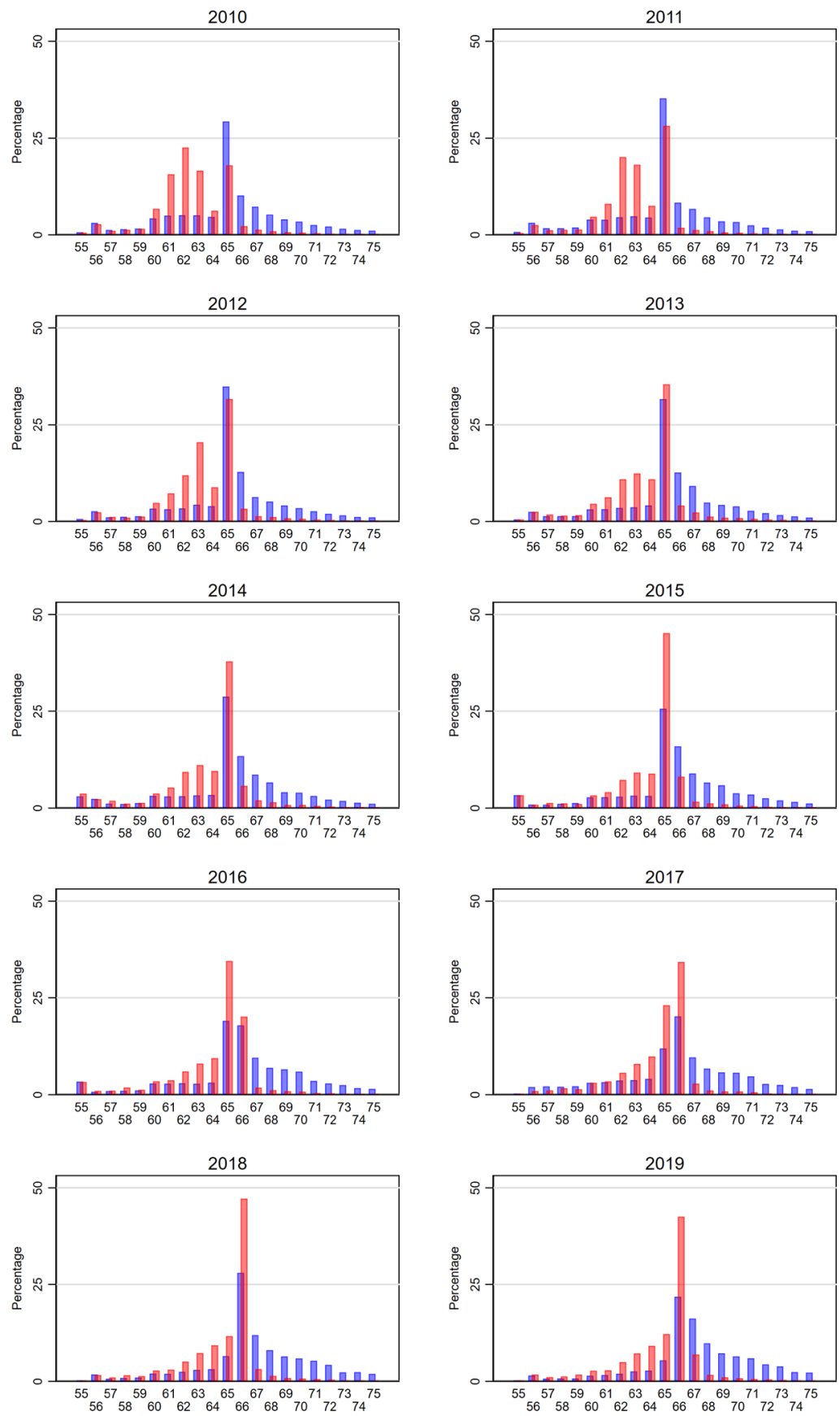

Zelfstandige

\section{Werknemer}

*Ten opzichte van de tweede editie van de monitor is er nog geen update beschikbaar 


\subsection{Alternatieven voor langer doorwerken: WW, ZW en WIA}

Niet elke persoon zal de mogelijkheid hebben om door te kunnen werken. De mogelijkheid bestaat dat mensen die niet langer kunnen doorwerken in de WW, ZW of WIA belanden. Doordat de vereisten voor arbeidsongeschiktheidsuitkeringen zijn aangescherpt, zal er naar verwachting maar een beperkte toename zijn van ouderen die arbeidsongeschikt worden (Staubli en Zweimuller, 2013; Lalive en Staubli, 2014), maar het niet helemaal uitgesloten worden dat mensen proberen gebruik te maken van deze uitkeringen om alsnog vervroegd uit te treden.

\section{Figuur 6}

Uitstroomkans van werk naar werkloosheids- of arbeidsongeschiktheidsuitkering*
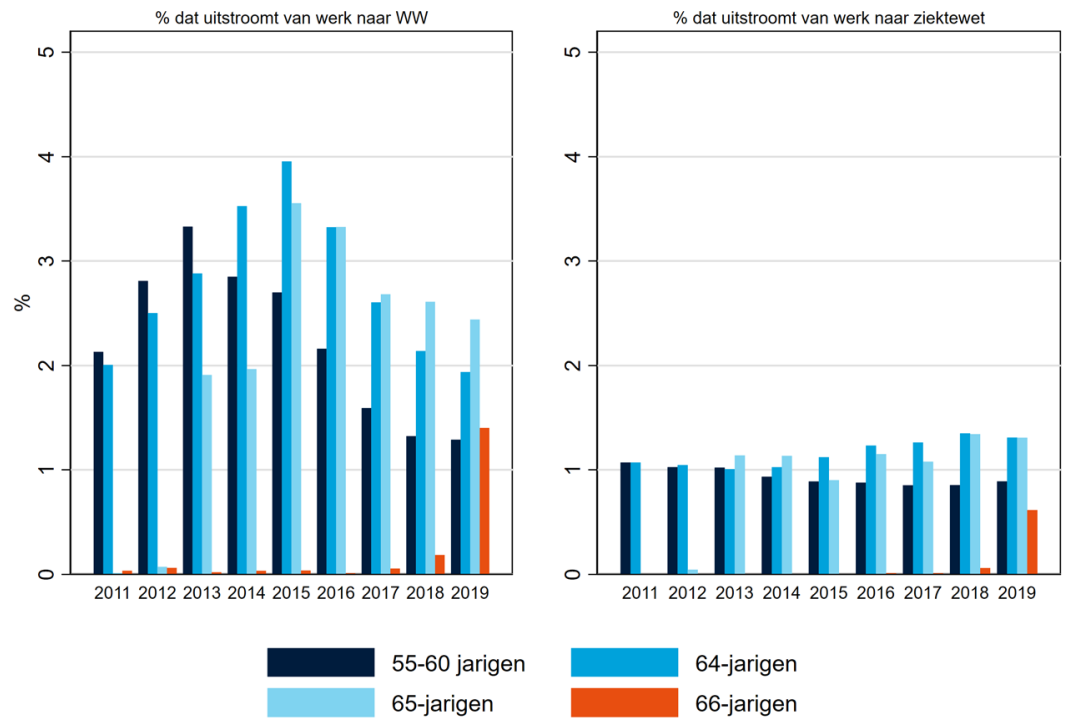

Bron: CBS Microdata. Bewerking door ROA

*Ten opzichte van de tweede editie van de monitor is er nog geen update beschikbaar

\section{Trends in de data}

Figuur 6 toont de uitstroom van werk naar de WW en de ziektewet voor 55-60-jarigen, 64, 65 en 66-jarigen. ${ }^{13}$ Ook hier geldt dat de data beschikbaar zijn tot en met 2019.

13 Relevant om hierbij op te merken is dat bij nieuwe betalingen van een WIA-uitkering nog geen onderscheid tussen uitkeringen als voorschot en definitieve WIA-uitkeringen wordt gemaakt. Er zijn allerlei redenen waarom een aanvraag niet binnen de gestelde wettelijke termijn afgehandeld kan worden en een voorschot verstrekt wordt. Een reden kan bijvoorbeeld zijn dat de benodigde stukken niet op tijd geleverd zijn door de klant. Er kunnen ook uitvoeringsredenen zijn (bijvoorbeeld een tekort aan artsen). Hierdoor wordt de uitstroom naar de WIA altijd licht overschat (Berendsen en Rijnsburger 2021). 
Het percentage dat uitstroomt van werk naar WW is sinds de verhoging van de AOW-leeftijd in eerste instantie toegenomen. In 2015 stroomde gemiddeld $4 \%$ van de 64-jarige werknemers door naar de WW of bijstand, en voor 65-jarigen was dat gemiddeld 3,6\%. Sinds 2016 is deze kans echter langzaam aan het afnemen, naar 2,4\% voor 65-jarigen en 1,4\% voor 64-jarigen in 2019. Dit is lager dan de uitstroomkansen in 2013. Echter, de uitstroomkans van 64- en 65-jarigen is sinds 2013 significant hoger dan voor 55-60-jarigen.

De kans dat 55-60-jarigen uitstromen van werk naar een ZW/WIA-uitkering is tussen 2011-2017 gedaald om vervolgens vanaf 2018 weer licht toe te nemen. De kans ligt voor deze periode onder de $1 \%$. Hoewel de kans op uitstroom naar een ZW/WIA-uitkering dus beperkt is, is deze kans wel lichtelijk hoger voor 64- en 65-jarigen. Dit kan komen doordat deze cohorten vanwege hun leeftijd in toenemende mate met gezondheidsproblemen worden geconfronteerd. ${ }^{14}$ Voor 66-jarigen kan op termijn eenzelfde patroon worden verwacht, maar het is op dit ogenblik nog net iets te vroeg om dit te observeren.

\section{Causale analyse}

Figuren 7 en 8 laten de voorspelde waarden zien van DiD regressies die het causale effect meten van de verhoging van de AOW-leeftijd op de kans dat mensen in de WW en de ziektewet zitten (bevat naast de uitstroom ook degenen die reeds in de WW en ziektewet zitten). Voor presentatiedoeleinden laten we uitsluitend resultaten zien van de controlegroep (cohort dat op 65-jarige leeftijd AOW krijgt), en twee interventiegroepen (de cohorten die op 65, en 6 maanden en 66 jaar AOW krijgen).

Voor de WW vinden we dat tot 65-jarige leeftijd de interventie-cohorten en het controle cohort een parallelle trend hebben met leeftijd in de kans op een WW-uitkering. Dit betekent dat voor al deze cohorten een licht positieve trend in de kans op een WW-uitkering wordt gevonden met leeftijd. Bovendien verschillen de kansen ook niet significant van elkaar.

We hebben de cijfers over de uitstroom naar de WW en de ziektewet ook uitgesplitst naar opleidings- en inkomensniveau. Gekeken naar opleiding (zie Appendix A) is sinds 2015 dezelfde negatieve trend in de uitstroom naar de WW zichtbaar voor elk opleidingsniveau. De uitstroomkans voor hoogopgeleiden daalt echter iets minder hard en komt iets boven de uitstroomkans voor laagopgeleiden te liggen. Wordt gekeken naar inkomensniveau (zie Appendix A), dan komt dezelfde neerwaartse trend sinds 2015 naar voren voor alle inkomensklassen, zonder al te grote verschillen tussen deze klassen. Opvallend is enkel de hoogste inkomensklasse (2 keer modaal of hoger): deze klasse heeft in 2019 een uitstroomkans van 2,4\%, wat gelijk is aan de uitstroomkans voor de klasse minimumloon tot modaal inkomen.

Wat betreft het de uitsplitsing van de uitstroom naar de WIA naar opleiding valt op dat uitstroomkans van werk naar ZW/WIA het hoogste is voor laagopgeleiden en deze sinds 2014 het meeste is toegenomen voor middelbaar opgeleiden van 65 jaar (van o,9\% naar 1,9\%). Ook zijn er verschillen tussen inkomensklassen (zie Appendix A): lagere inkomens (modaal of lager) hebben gemiddeld een hogere uitstroomkans. Net zoals bij de uitstroom naar de WW, zien we dat de uitstroom naar de ZW/WIA lager is voor 56-60-jarigen. 
Figuur 7

DiD resultaten WW (\% van populatie)

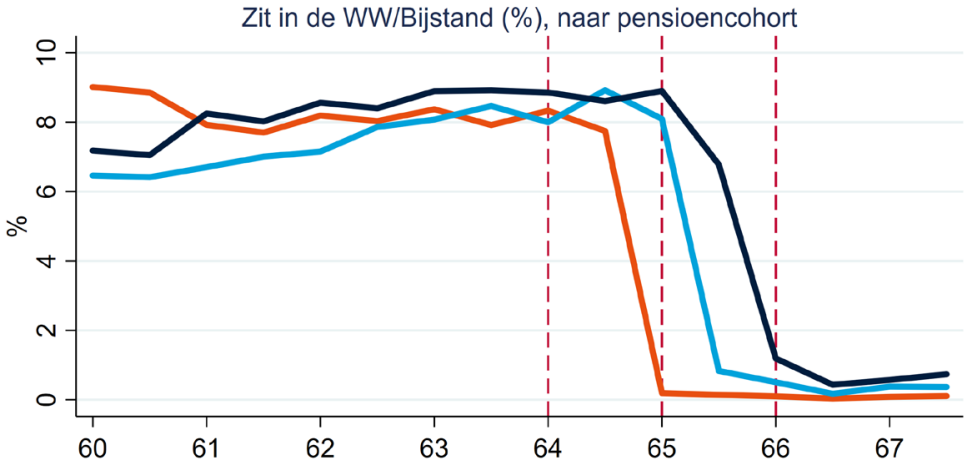

Cohort pensioenleeftijd:

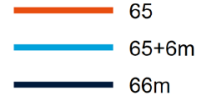

Bron: CBS Microdata, Bewerking ROA

\section{Figuur 8}

DiD resultaten Ziektewet / WIA (\% van populatie)

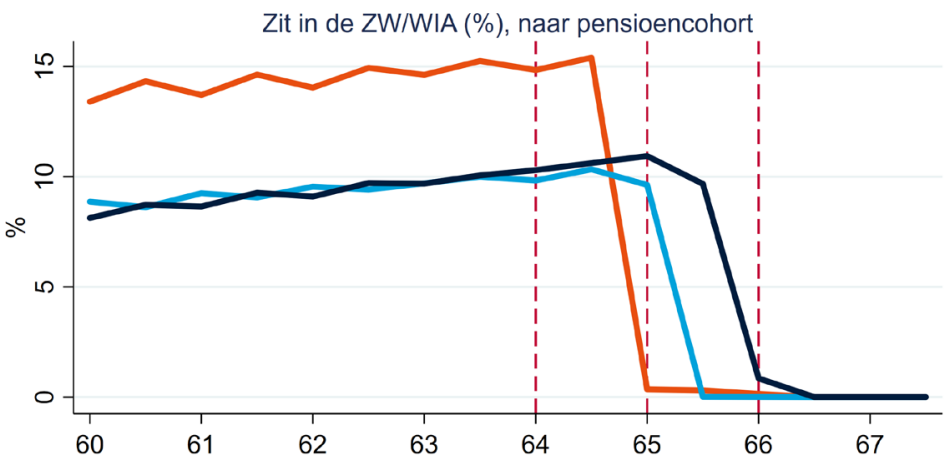

Cohort pensioenleeftijd:

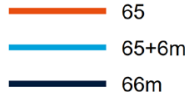

Bron: CBS Microdata, Bewerking ROA 
Figuur 7 laat vervolgens zien dat mensen in de interventiegroepen langer in de WW blijven zitten totdat zij de AOW-leeftijd hebben bereikt. We zien echter geen verhoogde uitstroom, ofwel er is niet sprake van aanzienlijke stijging in de trend voor de interventiegroepen tussen 65-jarige leeftijd en de AOW-leeftijd. Er is dus geen aanwijzing dat mensen doelbewust de WW gebruikt hebben als een alternatief om alsnog vervroegde uittreding te bewerkstelligen tussen hun 65ste levensjaar en hun AOW-leeftijd.

Figuur 8 toont eenzelfde beeld voor de kans op een ZW/WIA uitkering. Hoewel mensen in de controlegroep beduidend vaker een ZW/WIA uitkering hebben, valt uit de figuur af te lezen dat dat de trend in de kans op een uitkering met leeftijd parallel loopt aan die van de interventiegroepen. Mensen die pas later AOW krijgen, blijven langer gebruik maken van een ZW/WIA uitkering. Ook hier geldt dat het erop lijkt dat mensen niet doelbewust de ZW/WIA gebruikt hebben als een alternatief om alsnog vervroegde uittreding te bewerkstelligen tussen hun 65ste levensjaar en hun AOW-leeftijd. De trends lopen door totdat mensen hun AOW-leeftijd bereiken en vertonen geen uitzonderlijke pieken.

Samenvattend zien we dus dat er een causaal effect is van de verhoging van de AOW-leeftijd op het hebben van een WW of ZW/WIA uitkering. De absentie van stijging in de trends tussen het 65ste levensjaar en de AOW-leeftijd laat echter ook zien dat mensen in de interventiecohorten deze uitkeringen niet benutten als alternatief kanaal om vervroegde uittrede te bewerkstelligen. ${ }^{15}$

\subsection{Van WW naar werk}

De verhoging van de AOW-leeftijd vergroot niet alleen de kans dat mensen uitstromen naar de WW, WIA en ZW. Ook het omgekeerde is mogelijk. Het feit dat werkloze mensen langer op hun pensioen moeten wachten kan hen motiveren om meer te investeren in hun duurzame inzetbaarheid en om werk te gaan zoeken. Figuur 9 laat het percentage mensen zien die instromen van WW naar werk. Het betreft het percentage dat instroomt gerelateerd aan de populatie WW-gerechtigden?

Uit de figuur blijkt dat het percentage mensen die instromen van WW naar werk vanaf 2014 fors is toegenomen voor 64-jarigen en 65-jarigen, terwijl voor 66-jarigen niet veel verandering is opgetreden. 9,3\% van de 64-jarigen in de WW keert terug naar werk. Soortgelijke trends van een toename van de instroom van WW naar werk zijn ook zichtbaar voor jongere leeftijdsgroepen, waardoor niet valt uit te sluiten dat deze trend grotendeels is toe te schrijven aan de conjunctuur. ${ }^{16}$

15 De appendix toont de DiD resultaten uitgesplitst naar opleidingsniveau. Het causale effect van de verhoging van de AOW-leeftijd is zichtbaar voor alle leeftijdscategorieën. De effecten zijn sterker voor laagopgeleiden, maar dit komt omdat deze groep vaker een WW of ZW/WIA uitkering hebben.

16 Wanneer echter gekeken wordt naar de trend voor ouderen naar opleidingsniveau (zie Appendix A), is vooral een stevige stijging van WW naar werk zichtbaar voor laagopgeleiden. Hierbij speelt onder andere mee dat de groep hoogopgeleiden in de WW relatief klein is en derhalve selectie-effecten kunnen plaatsvinden. 
Figuur 9

Instroomkans uit WW naar werk*

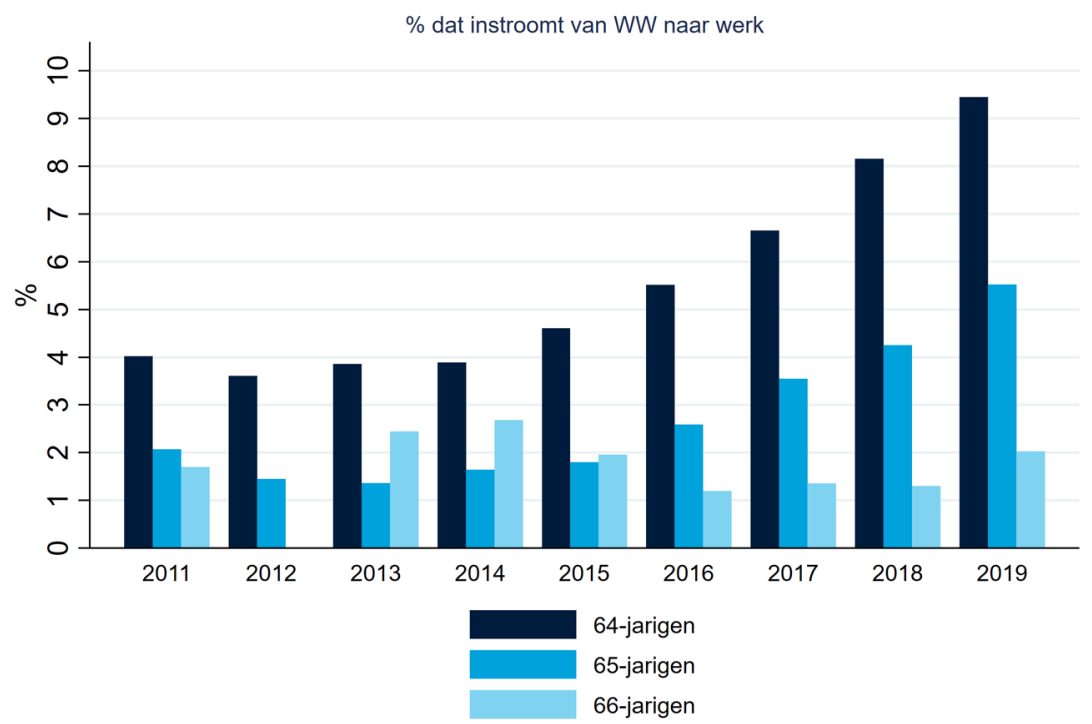

Bron: CBS Microdata. Bewerking door ROA

*Ten opzichte van de tweede editie van de monitor is er nog geen update beschikbaar

\subsection{Scholingsdeelname}

Om de inzetbaarheid van werknemers te vergroten is het van belang dat zijzelf en hun werkgever blijven investeren in hun menselijk kapitaal, vooral omdat de verhoging van de AOW-leeftijd ervoor zorgt dat de periode waarin investeringen in menselijk kapitaal kunnen renderen langer is. Dit zou zowel werkgevers als werknemers moeten stimuleren om meer te investeren.

\section{Trends in de data}

De data over scholings-en cursusdeelname zijn beschikbaar tot en met 2018 (EBB). Het aandeel werknemers dat scholing volgt is gedurende de periode 2009-2015 toegenomen. Met name vanaf 2012 is er een stijging in het aandeel werknemers dat een cursus volgt, met de grootste toename in scholing voor de leeftijdsklasse 56-60 jaar. Deze groep zag een toename van 6,8\%-punt deelname aan een cursus in de afgelopen vier weken in 2012 naar $17 \%$ deelname in 2016. Zorgwekkend is dat de scholingsdeelname de laatste drie jaar is gedaald naar 12\% in 2018. Dit is overigens niet alleen het geval voor oudere werknemers. Uit nadere analyses blijkt dat eenzelfde trend zichtbaar is voor de hele beroepsbevolking. 
Ook de stijging in de scholingsdeelname voor de leeftijdsklasse 61-65 jaar is aanzienlijk: gedurende de periode 2009-2015 stijgt de deelname van 4\% naar 9\%, een toename die bijna net zo groot is als voor de leeftijdsklasse 56-60 jaar. Echter, ook voor de groep is er een lichte kentering zichtbaar sinds 2016.

Als we kijken naar het verschil tussen opleidingsniveaus, dan valt op dat de laagopgeleiden minder deelnemen aan scholing en dat sinds 2012 dit verschil alleen maar groter is geworden, hoewel de kentering in scholingsdeelname sinds 2016 vooral hoogopgeleiden treft. Dit impliceert dus dat de inzetbaarheid van laagopgeleide ouderen mogelijkerwijs zal achterblijven.

\section{Figuur 10}

Scholingsdeelname* (\% van werkzame beroepsbevolking, gewogen)
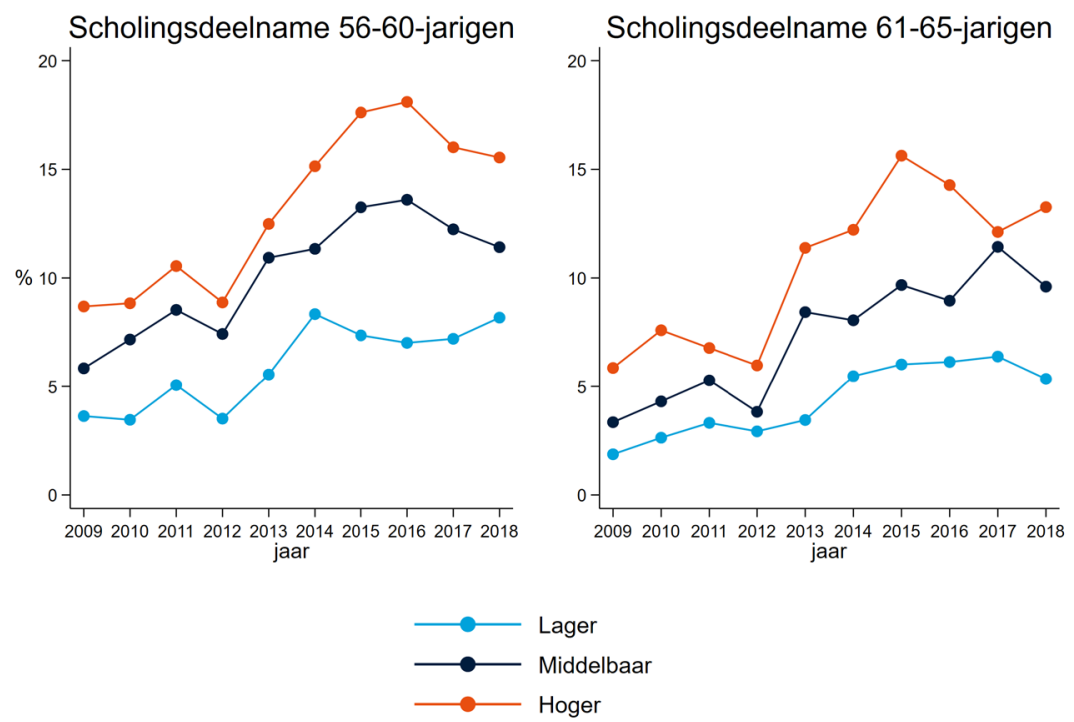

Bron: CBS Microdata. Bewerking door ROA

*Ten opzichte van de tweede editie van de monitor is er nog geen update beschikbaar

Figuur 11 laat zien wie voor de scholing betaalt. Duidelijk blijkt dat de recente daling in de scholingsdeelname vooral komt omdat cursussen die betaald worden door de werkgever zijn gedaald. Het percentage cursussen die niet betaald worden door de werkgevers is zelfs licht toegenomen voor 56-60-jarigen en ongeveer gelijk gebleven voor de 61-65-jarigen. Echter, er moet ook worden opgemerkt dat de sterke stijging in de scholingsdeelname tot 2016 vooral door de werkgever werd geïnitieerd. Bovendien, de daling sinds 2016 in de scholingsdeelname die betaald wordt door werkgevers bleef niet beperkt tot oudere werknemers. Eenzelfde daling was zichtbaar voor de hele beroepsbevolking. 


\section{Figuur 11}

Cursusdeelname: door wie betaald?* (\% van werkzame beroepsbevolking, gewogen)
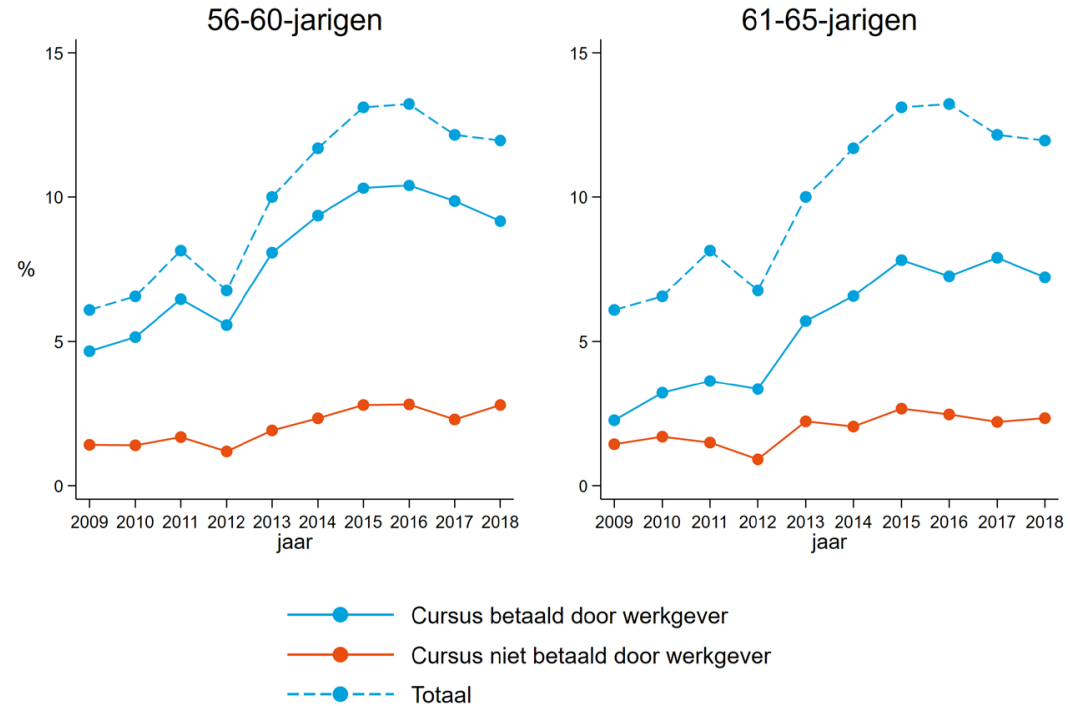

Bron: CBS Microdata. Bewerking door ROA

* Ten opzichte van de tweede editie van de monitor is er nog geen update beschikbaar

\subsection{Investeren in belastbaarheid}

Naar verwachting zullen werkgevers meer maatregelen treffen om taken te verlichten naarmate de AOW-leeftijd stijgt. Daarnaast kunnen ze ook inzetten op het motiveren van oudere werknemers en te investeren in hun menselijk kapitaal (door bijvoorbeeld het vergroten van trainingsaanbod) met als doel de inzetbaarheid van werknemers te vergroten.

\section{Trends in de data}

Tabel 2 geeft een indicatie van hoe het HR-beleid gericht op langer doorwerken zich heeft ontwikkeld over de jaren. Het betreft de voorzieningen / maatregelen om werknemers te laten doorwerken zoals gerapporteerd door een representatieve steekproef van werkgevers voor Nederland (WEA-enquête). ${ }^{17}$

Uit de tabel blijkt dat de meeste werkgevers geen speciale voorzieningen / maatregelen hebben getroffen. De meest populaire maatregelen weerspiegelen een klassiek ontziebeleid: er wordt vooral ingezet op extra vrije dagen voor oudere werknemers, taakverlichting en aanpassing van taken, en een kortere werkweek en werktijden.

17 Er wordt een weging toegepast die ervoor zorgt dat werkgevers in verschillende sectoren representatief vertegenwoordigd zijn. 
Er zijn enkele interessante trends. Zo wordt er minder geïnvesteerd in extra vrije dagen voor ouderen (waarschijnlijk is dit CAO-bepaald), en wordt er vooral meer ingezet op taakverlichting en aanpassing van taken. Voor deze laatste voorziening geldt dat er sprake is van bijna een verdubbeling van de inzet $(16,2 \%)$. Ook is er een voorzichtige tendens dat demotie iets vaker wordt ingezet (2,6\% in 2019) en geven werkgevers vaker aan een gezondheidsbeleid te voeren (4,1\% in 2019). Stimuleren van scholings- en cursusdeelname wordt daarentegen niet significant vaker ingezet. Dit laatste past ook bij de resultaten die eerder werden geobserveerd.

\section{Tabel 2}

Voorzieningen om werknemers te laten doorwerken

\begin{tabular}{|lrrrrr|}
\hline Voorzieningen om werknemers te laten doorwerken & 2010 & 2012 & 2014 & 2016 & 2019 \\
\hline Deeltijd vervroegde uittreding & 10 & 7,7 & 6 & 4,2 & 5,2 \\
\hline $\begin{array}{l}\text { Oudere werknemers vrijstellen van onregelmatige en } \\
\text { ploegendienst }\end{array}$ & 5,5 & 5 & 5,7 & 5,6 & 6,1 \\
\hline Kortere werkweek / aanpassing werktijden & 14,6 & 15,6 & 12,3 & 14,5 & 17,4 \\
\hline Extra vrije dagen oudere werknemers & 24,1 & 22,2 & 18,8 & 20,5 & 18,6 \\
\hline Stimuleren scholings- en cursusdeelname & 6,2 & 6,9 & 6,6 & 7,1 & 7 \\
\hline Taakverbreding/taakroulatie & 4,1 & 4 & 3,6 & 4,5 & 4,2 \\
\hline Taakverlichting en of aanpassingen takenpakket & 9,8 & 10,7 & 11,8 & 15 & 16,2 \\
\hline Loopbaan en functioneringsgesprekken & 8,4 & 9 & 9,3 & 10,9 & 9,8 \\
\hline Omscholen naar andere baan / functie & 2 & 2,1 & 1,7 & 2,4 & 2,1 \\
\hline Teruggang salaris / functie & 1,9 & 1,8 & 1,8 & 1,9 & 2,6 \\
\hline Aanpassen van de werkplek & 7,5 & 8,2 & 5,6 & 6,3 & 7,2 \\
\hline Gezondheidsbeleid & 3,5 & 3,9 & 3,4 & 3,1 & 4,1 \\
\hline Er zijn geen voorzieningen / maatregelen getroffen & 63,7 & 63,2 & 60,7 & 60,4 & 58,9 \\
\hline Bron WEA / TNO & & & & &
\end{tabular}

Bron WEA / TNO 



\section{Uitkomsten voor werk, inkomen en gezondheid}

Het doel van de verhoging van de AOW-leeftijd is tweeledig: ten eerste moet de verhoging ervoor zorgen dat de arbeidsparticipatie hoger komt te liggen, en ten tweede zullen de AOW-lasten verlaagd worden vanwege de hogere arbeidsparticipatie. In het vorige hoofdstuk zijn de acties besproken die worden ondernomen door zowel werkgevers als werknemers om de inzetbaarheid en belastbaarheid van ouderen te vergroten, zodat de gestelde doelen van het verhogen van de AOW-leeftijd bereikt kunnen worden. Deze acties brengen echter ook neveneffecten met zich mee. Mensen doen langer een beroep op arbeidsongeschiktheids- en werkloosheidsuitkeringen.

In dit hoofdstuk worden de uitkomsten besproken voor de arbeidsmarkt: er wordt gekeken in hoeverre de verwachte uitkomsten zich gerealiseerd hebben.

\subsection{Arbeidsmarkt en inkomen}

\section{Arbeidsparticipatie van ouderen neemt toe}

Door de verhoging van de AOW-leeftijd werken veel ouderen langer door terwijl de uitstroom van werk naar WW en WIA beperkt blijft. Daardoor kunnen we verwachten dat de arbeidsparticipatie toeneemt. 
Figuur 12

Belangrijkste inkomstenbron*
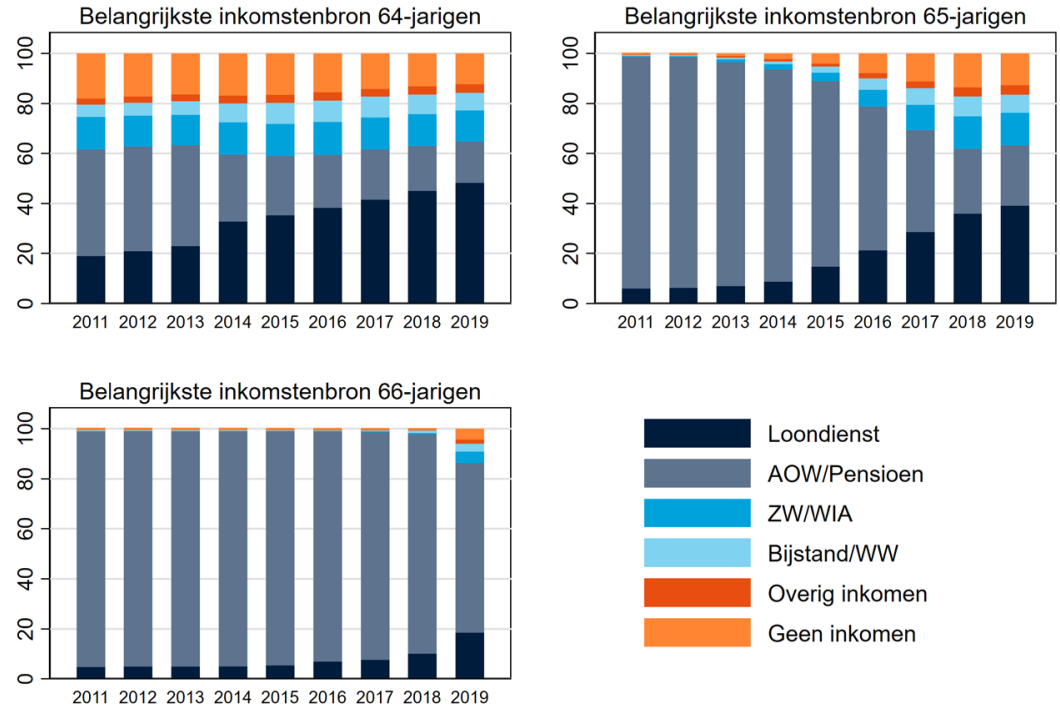

Bron: CBS Microdata. Bewerking door ROA

*Ten opzichte van de tweede editie van de monitor is er nog geen update beschikbaar

\section{Trends in de data}

Figuur 12 laat zien dat de arbeidsparticipatie van 65-jarigen fors is toegenomen sinds de verhoging van de AOW-leeftijd in 2012. Tegelijkertijd is het percentage mensen die AOW / pensioen als belangrijkste inkomensbron hebben sterk gedaald voor deze groep. Met name vanaf 2013, als de AOW-leeftijd op 65 jaar komt te staan, zet de afname sterk door. Het percentage inkomen uit werk in de periode 2012-2019 is voor 65-jarigen gestegen van $6 \%$ naar $39 \%$. Voor 64 -jarigen is dit percentage gestegen van $21 \%$ naar $48 \%$.

Voor 66-jarigen vinden dezelfde ontwikkelingen gematigder plaats gedurende deze periode, maar vanaf 2018 op 2019 zien we eveneens sterke veranderingen: het inkomen uit werk neemt toe van 10\% naar 19\%. Inkomen uit pensioen of AOW voor 66-jarigen daalt van 88\% naar 68\% tussen 2018 en 2019. Vooral het aandeel in loondienst neemt relatief sterk toe voor 66-jarigen. Het aandeel is tussen 2018 en 2019 drie keer zo groot geworden, van $4 \%$ naar $12 \%$, terwijl het aandeel zelfstandigen stijgt van $4 \%$ naar $5 \%$.

\section{Causale analyses}

Het effect van de verhoging van de AOW-leeftijd hebben we ook causaal onderzocht door middel van een DiD analyse. De voorspelde waarden van het model laten duidelijk zien dat de resultaten voor de arbeidsparticipatie ongeveer het gespiegelde verloop vertonen van het pensioengedrag (zie Figuur 13). De arbeidsparticipatie loopt tot 62 jaar en 6 maanden nog ongeveer parallel tussen de interventiegroepen en de controlegroep. Wel geldt dat de participatie in de controlegroep ruim 20\%-punten lager ligt, o.a. doordat zij minder sterk zijn getroffen door andere hervormingen in het pensioenstelsel 
(o.a. de invoering van het middelloonstelsel). Vanaf 63-jarige leeftijd zien we daarentegen we een daling in de arbeidsparticipatie van deze groep van $40 \%$ naar $15 \%$. Ook hier geldt dat de oorzaak is dat de controlegroep nog aanspraak kon maken op prepensioenregelingen waarvoor de normleeftijd rond 63 jaar lagen. Pas op 65 -jarige leeftijd zien we weer een forse daling in de arbeidsparticipatie. Voor de interventiegroepen observeren wij eveneens drie belangrijke veranderingen in de trends. Allereerst, als gevolg dat jongere cohorten geen recht meer hadden op prepensioen, verloopt de trend na 63 jaar tot de AOW-leeftijd veel vlakker voor de interventiegroepen. Ten tweede, de daling in de arbeidsparticipatie accelereert pas als mensen de AOW-leeftijd bereiken. Ten derde, de piek rondom de AOW-leeftijd is iets sterker geworden ( $21 \%$ daling voor degenen die pas AOW krijgen op 66-jarige leeftijd). Deze drie veranderingen in de trends van de arbeidsparticipatie kunnen als het causale effect van de verhoging van de AOW-gerechtigde leeftijd worden geïnterpreteerd. ${ }^{18}$

\section{Effect op inkomen}

Het rendement van de verhoging van de AOW-leeftijd vertaalt zich niet alleen in de arbeidsparticipatie, maar ook in het inkomen dat ouderen verdienen. Of het inkomenseffect van het verhogen van de AOW-leeftijd positief of negatief is, hangt af van de stijging van de feitelijke uittreedleeftijd, of mensen bijsparen en de pensioenrechten die zij in de tweede pijler van het systeem hebben opgebouwd.

\section{Figuur 13}

DiD resultaten arbeidsparticipatie (\% van populatie)

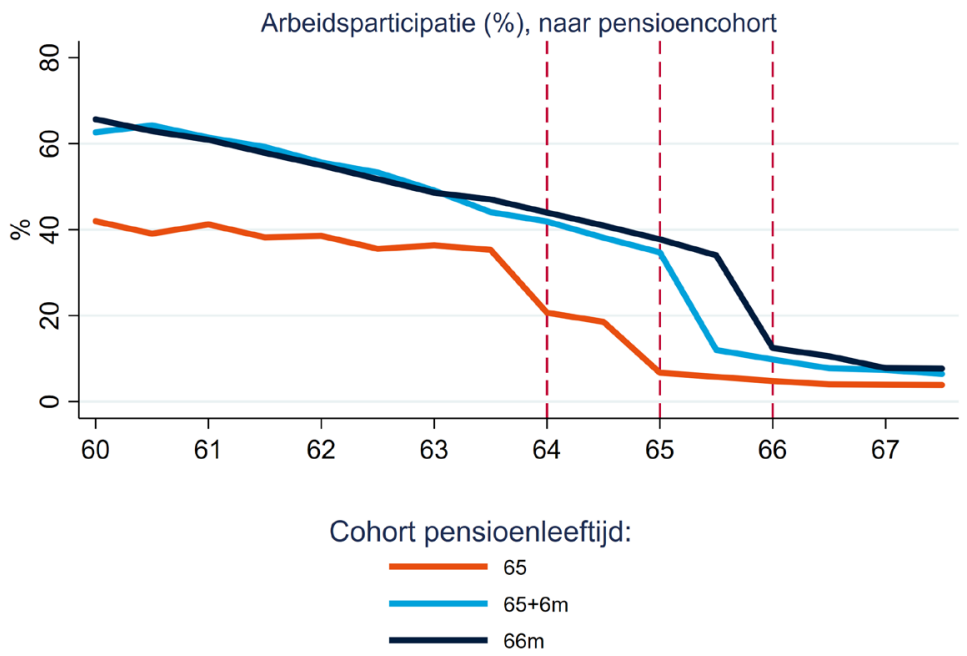

Bron: CBS Microdata, Bewerking ROA

18 De appendix laat zien dat het causale effect van de verhoging van de AOW-leeftijd op arbeidsparticipatie aanwezig is voor alle opleidingsniveaus, hoewel de arbeidsparticipatie voor laagopgeleiden doorgaans lager is. Voor middelbaar en hoogopgeleiden valt op dat de arbeidsparticipatie in het controlecohort altijd lager ligt dan die voor de andere interventiecohorten. Voor laagopgeleiden neemt is het verschil veel kleiner. Dit wordt veroorzaakt door het relatief lage pensioen dat laagopgeleiden hebben opgebouwd en het relatief zware gewicht van de AOW hierin. Zij hadden hierdoor minder financiële mogelijkheden om met vervroegd pensioen te gaan dan middelbaar opgeleiden en hoogopgeleiden die massaal gebruik hebben gemaakt van de prepensioenregeling. 


\section{Trends in de data}

Figuur 14 laat zien dat het bruto-inkomen vanaf 2009 onafgebroken is gestegen voor 64-, 65- en 66-jarigen. Deze stijging in het bruto-inkomen van 64-, 65- en 66-jarigen moet niet direct in verband gebracht worden met de verhoging van de AOW-leeftijd. Het inkomen van 66-jarigen volgt dezelfde stijgende trend als het inkomen van 64- en 65-jarigen, terwijl het inkomen van 66-jarigen voor het grootste deel van de gerapporteerde periode nog niet wordt beïnvloed door de stijging van de AOW-leeftijd. Vermoedelijk hangt dit samen met de economische groei en cohort-effecten. Kijkend naar de verschillen in inkomens tussen de drie leeftijdsgroepen door de jaren heen laat wel zien dat het inkomensverschil tussen de groepen langzaam iets groter wordt.

\section{Figuur 14}

Ontwikkeling Bruto inkomen*

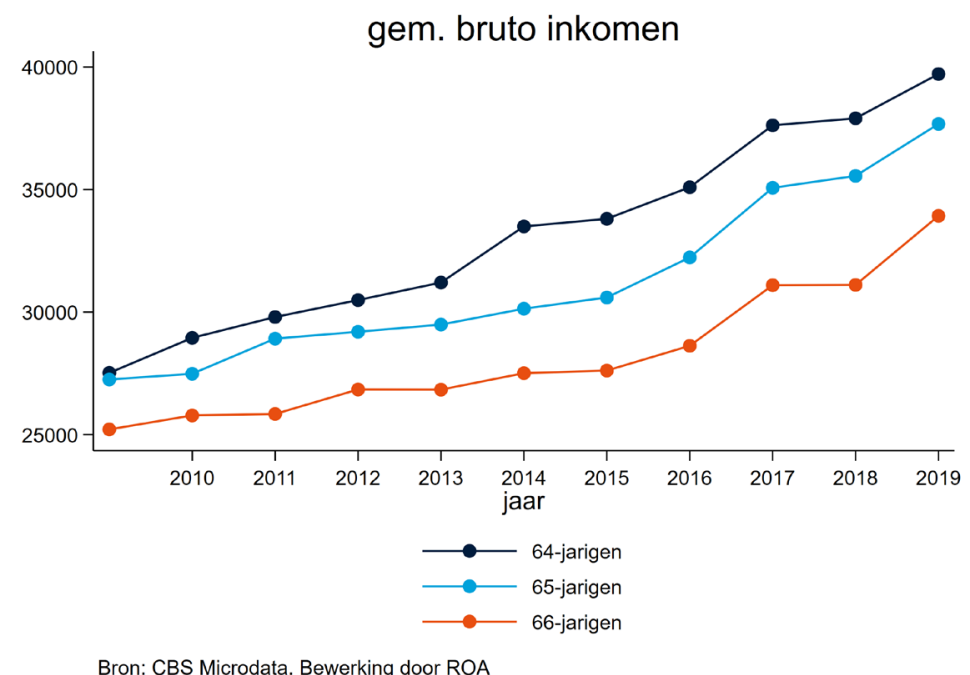

Bron: CBS Microdata. Bewerking door ROA

* Ten opzichte van de tweede editie van de monitor is er nog geen update beschikbaar 


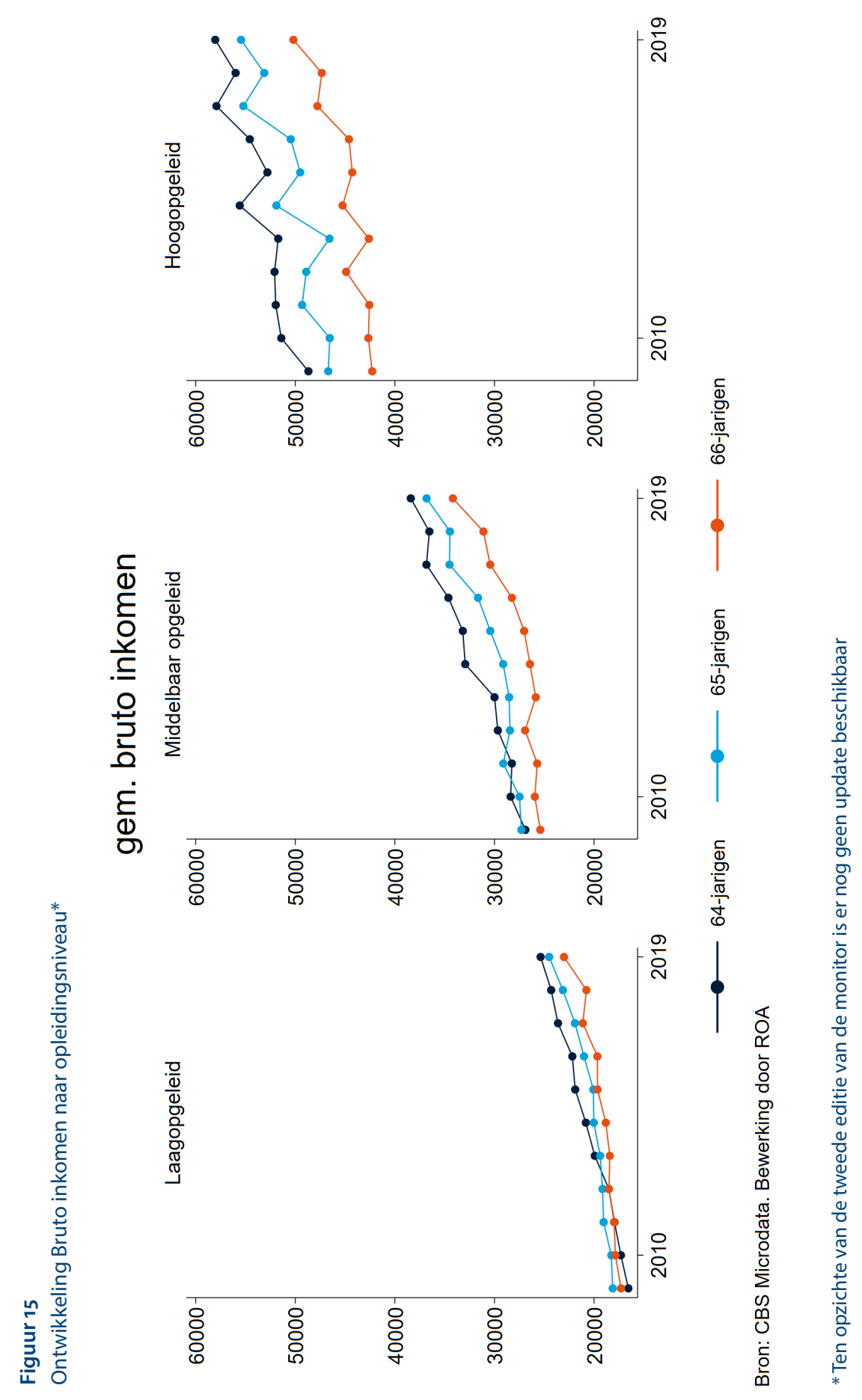


Figuur 15 toont de trends in het bruto-inkomen naar opleidingsniveau. Met behulp van deze uitsplitsing wordt het duidelijker waar de oorsprong van de uitwaaiering van inkomens tussen de leeftijden vandaan komt. In 2019 verdient een 66-jarige hoogopgeleide ongeveer $€ 8000$ minder dan een 64 -jarige. Dit verschil bedraagt ongeveer $€ 4000$ voor middelbaar opgeleiden en $€ 2000$ voor laagopgeleiden. In 2009 waren deze verschillen veel kleiner voor laagopgeleiden en middelbaar opgeleiden. Bij hoogopgeleiden blijft dit verschil ongeveer gelijk. De uitwaaiering is het sterkst voor de middelbaar opgeleiden.

\section{Causale analyses}

Om de causale impact te meten hebben we eveneens DiD analyses uitgevoerd op het inkomen, ook uitgesplitst naar opleidingsniveau.

\section{Figuur 16}

DiD resultaten bruto inkomen

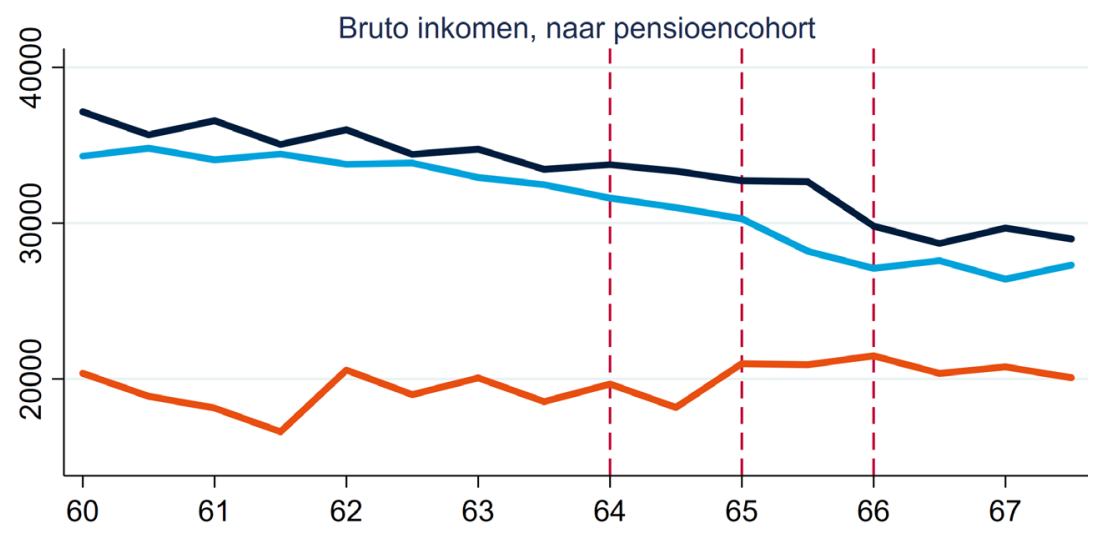

Cohort pensioenleeftijd:

65

De resultaten in figuur 16 tonen geen significante impact van de verhoging van de AOW-leeftijd op het inkomen. Dit is ook het geval als we uitsplitsen naar opleidingsniveau. Dit betekent dat de verhoging van de AOW-leeftijd dus hoogstwaarschijnlijk niet verantwoordelijk is voor de uitwaaiering in het inkomen over de jaren heen tussen de verschillende leeftijdsgroepen. Daarnaast is dit resultaat consistent met de stijgende arbeidsparticipatie. Het toont impliciet bewijs voor dat de meeste werknemers ervoor kiezen om hun inkomen constant te houden en niet veel inkomen na hun pensionering willen inleveren en derhalve langer participeren op de arbeidsmarkt. 


\subsection{Inzetbaarheid en gezondheid}

De verhoging van de AOW-leeftijd kan zowel negatieve als positieve effecten hebben op de gezondheid. Enerzijds kan deze demotiverend werken ${ }^{19}$, en problematisch zijn voor mensen die in zware beroepen zitten. Anderzijds kan pensionering ook leiden tot verbetering van de gezondheid als mensen hierdoor langer lichamelijk en cognitief actief blijven. Recent onderzoek van het RVIM laat zien dat de gezondheid onder ouderen relatief stabiel is gebleven (RVIM 2020). De vraag is echter of de AOW-leeftijd mogelijkerwijs alsnog een causaal effect heeft gehad op de gezondheid?

\section{Trends in de data}

Figuur 17 laat het percentage werknemers en zelfstandigen van 56-60 jaar en 61-65 jaar zien dat aangeeft te kunnen voldoen aan de fysieke en psychische eisen van het werk. Voor werknemers is voor wat betreft fysieke eisen geen patroon te herkennen door de jaren heen. Voor het voldoen aan psychische eisen is eveneens geen duidelijk patroon zichtbaar voor de werknemers afgezien dat laagopgeleiden iets beter voldoen aan psychische eisen vergeleken met hoogopgeleiden.

Voor zelfstandigen is een negatieve trend zichtbaar tot 2017 voor zowel de fysieke als psychische eisen. Vanaf 2017 is er weer sprake van herstel. Het is onwaarschijnlijk dat deze dalingen te maken hebben met de verhoging van de AOW-leeftijd, aangezien zelfstandigen veel flexibeler met pensioen gaan en niet geconfronteerd worden met functioneel leeftijdsontslag. In tegenstelling tot werknemers kunnen zij vaker doorwerken na de AOW-leeftijd.

19 Studies van De Grip et al. 2012; Montizaan et al. 2016 en Montizaan en Vendrik 2014. 
Figuur 17

Kunnen voldoen aan fysieke en psychische eisen*

$\%$ werknemers dat makkelijk kan voldoen aan...
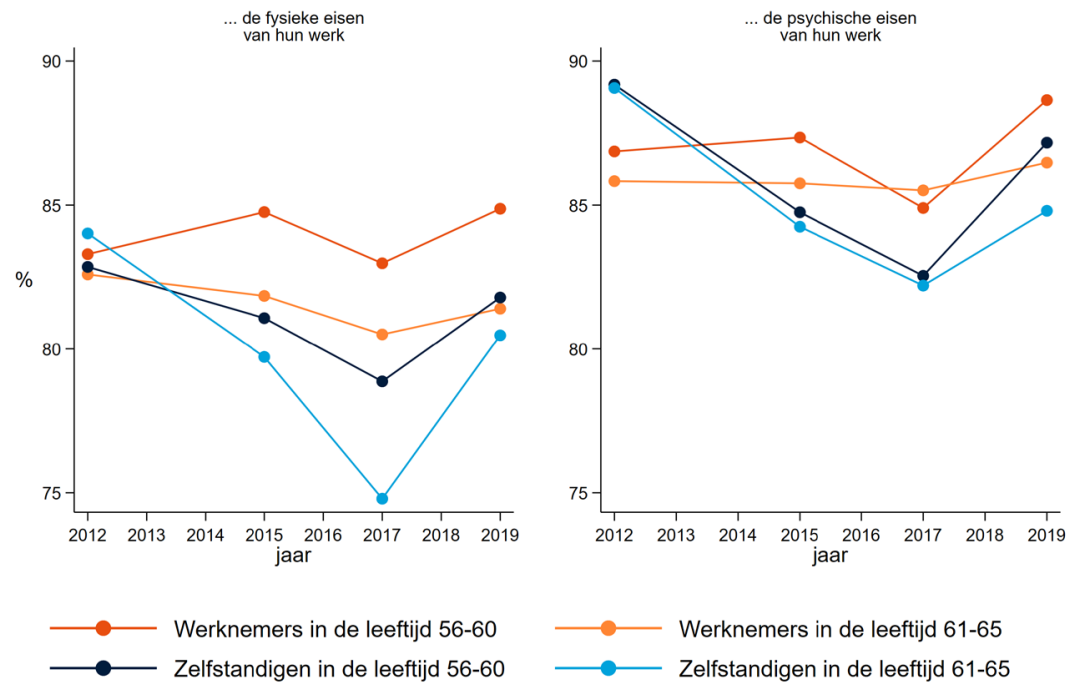

Bron: CBS Microdata. Bewerking door ROA

* Ten opzichte van de tweede editie van de monitor is er nog geen update beschikbaar

Een andere belangrijke indicator voor de inzetbaarheid is de ervaren gezondheid (Tabel A10 toont de ervaren gezondheid voor 64,65 en 66 -jarigen). Het percentage dat een goede tot zeer goede gezondheid ervaart schommelt in de periode 2010-2020 zonder dat hier een duidelijk patroon in te herkennen is. Hiermee zijn dus onze resultaten consistent met die zijn gevonden door het RVIM.

Het gebrek aan significante trends in de gemiddelde ervaren gezondheid komt eveneens tot uiting in de trend van de gemiddelde levensverwachting (Figuur 18). In Nederland is sprake van een lichte toename van de gezonde levensverwachting als gevolg van verbeteringen in de gezondheidszorg en gezonde leefstijl. Echter, er zijn geen significante verschillen te onderscheiden op het moment dat de AOW-leeftijd is verhoogd. 
Figuur 18

Ervaren gezondheid naar opleidingsniveau

\section{Levensverwachting in...}

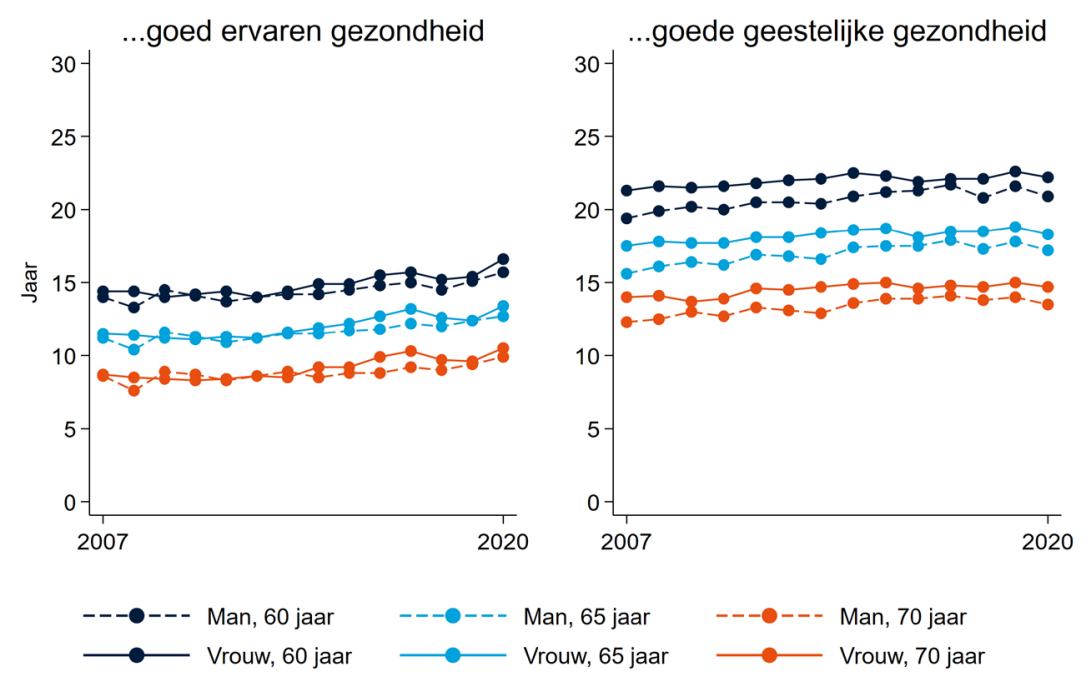

Bron: CBS Microdata. Bewerking door ROA

\section{Causale analyses}

We hebben een tweetal analyses uitgevoerd om het effect van de verhoging van de AOW-leeftijd op de ervaren gezondheid te meten. Allereerst hebben we DiD analyses uitgevoerd die direct het causale effect meten. De DiD liet zien dat er geen statistisch significant effect is van de verhoging van de AOW-leeftijd op de ervaren gezondheid. De figuren van de voorspelde waarde van het DiD model vertonen veel fluctuaties die nietgerelateerd zijn aan de verhoging van de AOW-leeftijd en worden derhalve niet getoond.

Een tweede analyse die wij hebben uitgevoerd is om vast te stellen of met pensioen gaan een negatief of positief effect heeft op de ervaren gezondheid. Daartoe is een Instrumentele Variabele (IV) analyse uitgevoerd waarbij pensionering wordt geïnstrumenteerd met de AOW-interventie dummievariabelen die meten wanneer mensen recht hebben op AOW.

Uit tabel 3 blijkt dat het effect op de ervaren gezondheid niet statistisch significant is. Het negatieve teken van de coëfficiënt laat echter ook zien dat als er een effect zou zijn, pensionering eerder een negatieve impact zou hebben op de ervaren gezondheid dan een positieve impact. 
Tabel 3

IV analyses op de ervaren gezondheid (instrument: AOW-interventiedummievariabelen)

\begin{tabular}{ll} 
IV Resultaten & Ervaren gezondheid \\
\hline Pensioen (geïnstrumenteerd) & $-0,236$ \\
Cragg-Donald Wald F-stat & $79,96^{* * *}$ \\
Observaties & 9.747
\end{tabular}

Bron: CBS microdata. Bewerking door ROA. ${ }^{* *}$ is statistisch significant op $1 \%$ niveau. De CraggDonald Wald F-stat geeft aan dat de AOW-interventiedummievariabelen een sterk instrument is voor de kans om met pensioen te zijn. 


\section{Literatuur}

\section{Literatuuropsomming rapport}

Berendsen, E., en Rijnsburger, P. (2021). Volumeontwikkelingen voorjaar 2021, UWV Kennisverslag 2021-4, Amsterdam

De Grip, A., Künn, A., \& Montizaan, R. (2019). Raamwerk Evaluatie Interventies Leven Lang Ontwikkelen. ROA. ROA Reports No. 002 https://doi.org/10.26481/umarep.2019002

Jongen, E., Rabaté, S., \& Atav, T. (2019). The effects of the increase in the retirement age in the Netherlands (No. 408. rdf). CPB Netherlands Bureau for Economic Policy Analysis.

Ministerie van Sociale Zaken en Werkgelegenheid / SEO. Effect verhoging AOW-leeftijd. Resultaten monitor-en literatuuronderzoek-Rapport-Kennisplatform Werk enInkomen. 2020.

Van der Noordt, M., van der Lucht, F., Polder, J. J., Hilderink, H. B. M., \& Plasmans, M. H. D. (2020). Gezondheid en arbeidsparticipatie rond de AOW-leeftijd: Verwachte ontwikkelingen tot 2040. RIVM-rapport 2019-0219.

\section{Literatuuropsomming artikel in tijdschrift}

Ardito, C. (2021). The unequal impact of raising the retirement age: Employment response and program substitution. IZA Journal of Labor Economics, 10(1).

Blau, D., \& Goodstein, R. M. (2010). Can Social Security Explain Trends in Labor Force Participation of Older Men in the United States? Journal of Human Resources, 45(2), 328-363.

Borsch-Supan, A. (2000). A Model Under Siege: A Case Study of the German Retirement Insurance System. The Economic Journal, 110(461), F24-F45.

Coile, C., \& Gruber, J. (2007). Future Social Security Entitlements and the Retirement Decision. The Review of Economics and Statistics, 89(2), 234-246.

De Grip, A., Fouarge, D., \& Montizaan, R. (2013). How Sensitive are Individual Retirement Expectations to Raising the Retirement Age? De Economist, 161(3), 225-251.

De Grip, A., Lindeboom, M., \& Montizaan, R. (2012). Shattered Dreams: The Effects of Changing the Pension System Late In the Game. The Economic Journal, 122(559), 1-25.

Fetter, D. K., \& Lockwood, L.M. (2018). Government Old-Age Support and Labor Supply: Evidence from the Old Age Assistance Program. American Economic Review, 108(8), 21742211.

Knoef, M., Been, J., Caminada, K., Goudswaard, K., \& Rhuggenaath, J. (2017). De toereikendheid van pensioenopbouw na de crisis en pensioenhervormingen. Netspar Design Paper, 68.

Krueger, A. B., \& Pischke, J. (1992). The Effect of Social Security on Labor Supply: A Cohort Analysis of the Notch Generation. Journal of Labor Economics, 10(4), 412-437.

Lalive, R., \& Staubli, S. (2014). How does raising women's full retirement age affect labor supply, income, and mortality? Evidence from Switzerland. In Joint Meeting of the Retirement Research Consortium Conference Volume.

Lindeboom, M., \& Montizaan, R. (2020). Disentangling retirement and savings responses. Journal of Public Economics, 192(December 2020). 
Montizaan, R., Goedhart, R., \& Bijlsma, I. (2021). AOW Monitor 2021: Effect van verhoging van de AOW leeftijd op werk, inkomen en gezondheid. ROA. ROA Reports No. 002 https://doi. org/10.26481/umarep.2021002

Montizaan, R. M., de Grip, A., Cörvers, F., \& Dohmen, T. J. (2016). The impact of negatively reciprocal inclinations on worker behavior: Evidence from a retrenchment of pension rights. Management Science, 62(3), 668-681.

Montizaan, R. M., \& Vendrik, M. C. M. (2014). Misery loves company: exogenous shocks in retirement expectations and social comparison effects on subjective well-being. Journal of Economic Behavior \& Organization, 97, 1-26.

Staubli, S., \& Zweimüller, J. (2013). Does raising the early retirement age increase employment of older workers? Journal of public economics, 108, 17-32.

Mastrobuoni, 2009; Gelber et al., 2016. 


\section{Appendix A: Cijfers Figuren}

\section{Figuur A1}

Gemiddelde pensioenleeftijd naar inkomensklasse

\section{Gemiddelde pensioenleeftijd}
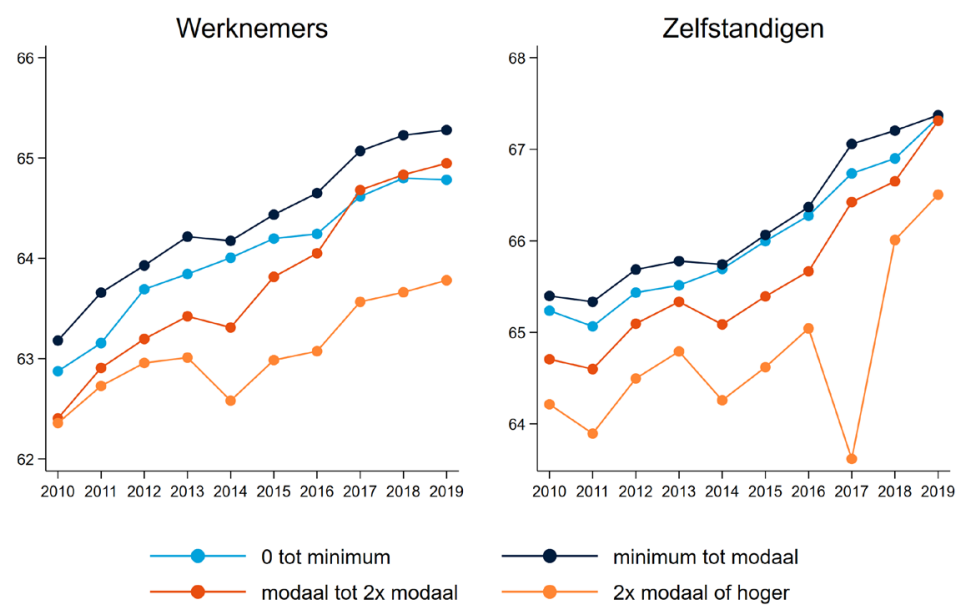

Bron: CBS Microdata. Bewerking door ROA

\section{Figuur A2}

DiD analyse: Bijstand / WW naar opleidingsniveau
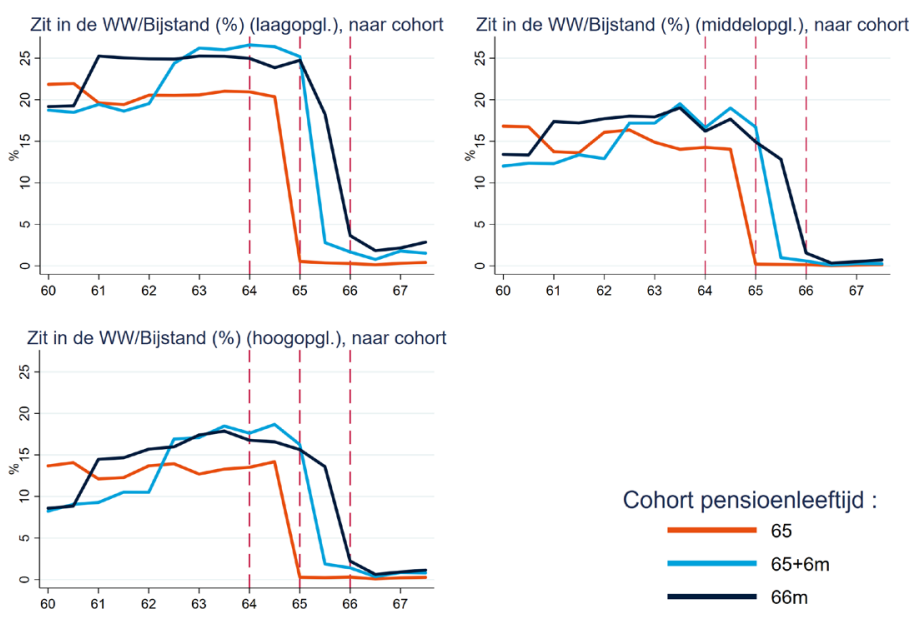

Cohort pensioenleeftijd :

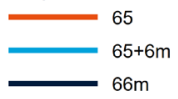

Bron: CBS Microdata. Bewerking door ROA 
Figuur $\mathrm{A}_{3}$

DiD analyse: ZW / WIA naar opleidingsniveau
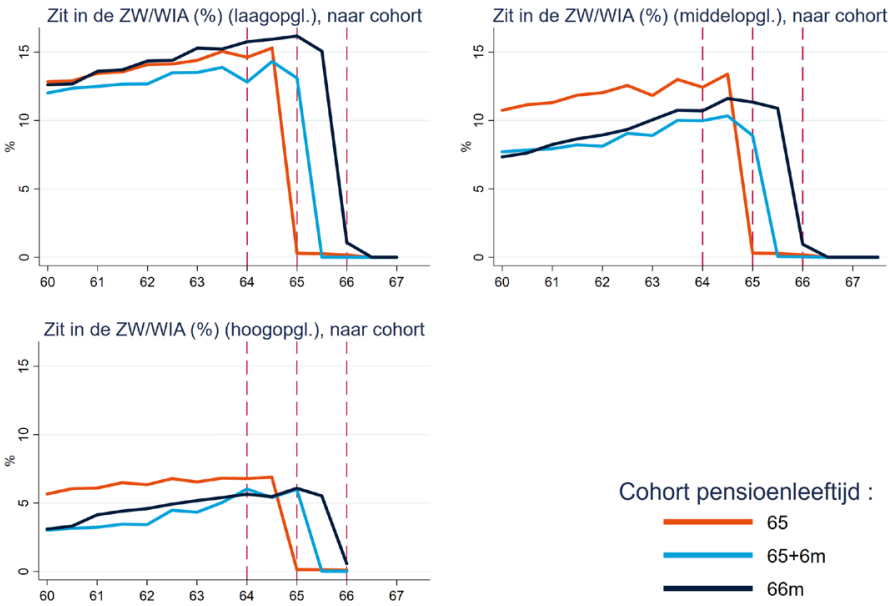

Cohort pensioenleeftijd :

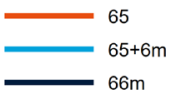

Bron: CBS Microdata. Bewerking door ROA

\section{Figuur A4}

DiD analyse: Arbeidsparticipatie naar opleidingsniveau
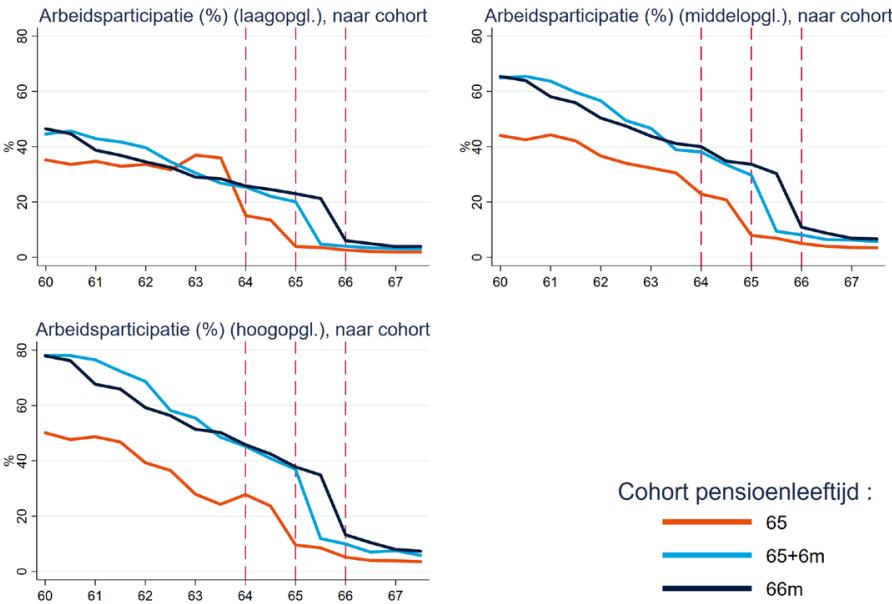

Cohort pensioenleeftijd :

Bron: CBS Microdata. Bewerking door ROA 
Tabel A1.1

Leeftijd tot welke mensen willen en denken te kunnen werken

\begin{tabular}{|c|c|c|c|c|}
\hline Jaar & 2012 & 2015 & 2017 & 2019 \\
\hline \multicolumn{5}{|c|}{ Gemiddelde leeftijd tot welke mensen willen werken } \\
\hline \multicolumn{5}{|l|}{ Werknemers } \\
\hline Leeftijdsklasse 56-60 & 64,1 & 64,7 & 64,6 & 64,5 \\
\hline Leeftijdsklasse 61-65 & 65,1 & 65,6 & 65,8 & 65,7 \\
\hline \multicolumn{5}{|l|}{ Zelfstandigen } \\
\hline Leeftijdsklasse 56-60 & 66,5 & 66,4 & 66,3 & 66,9 \\
\hline Leeftijdsklasse 61-65 & 69,4 & 68,5 & 67,9 & 67,6 \\
\hline \multicolumn{5}{|c|}{ Gemiddelde leeftijd waar tot mensen in staat zijn om te werken } \\
\hline \multicolumn{5}{|l|}{ Werknemers } \\
\hline Leeftijdsklasse 56-60 & 64,5 & 65,1 & 64,8 & 64,7 \\
\hline Leeftijdsklasse 61-65 & 66,1 & 66,3 & 66,2 & 66,1 \\
\hline \multicolumn{5}{|l|}{ Zelfstandigen } \\
\hline Leeftijdsklasse 56-60 & 67,6 & 67,6 & 67,0 & 68,2 \\
\hline Leeftijdsklasse $61-65$ & 70,2 & 69,8 & 69,2 & 69,0 \\
\hline
\end{tabular}

Bron: CBS Microdata (NEA). Bewerking door ROA 


\section{Tabel A1.2}

Leeftijd tot welke mensen willen en denken te kunnen werken, naar opleiding

\begin{tabular}{|c|c|c|c|c|c|}
\hline Jaar & & 2012 & 2015 & 2017 & 2019 \\
\hline \multicolumn{6}{|c|}{ Gemiddelde leeftijd tot welke mensen willen werken } \\
\hline \multicolumn{6}{|l|}{ Werknemers } \\
\hline Laagopgeleid & Leeftijdsklasse 56-60 & 64,0 & 64,7 & 64,5 & 64,6 \\
\hline Laagopgeleid & Leeftijdsklasse 61-65 & 65,0 & 65,7 & 65,8 & 65,7 \\
\hline Middelbaar opgeleid & Leeftijdsklasse 56-60 & 63,9 & 64,6 & 64,5 & 64,3 \\
\hline Middelbaar opgeleid & Leeftijdsklasse 61-65 & 65,2 & 65,5 & 65,8 & 65,6 \\
\hline Hoogopgeleid & Leeftijdsklasse 56-60 & 64,3 & 64,9 & 64,8 & 64,6 \\
\hline Hoogopgeleid & Leeftijdsklasse 61-65 & 65,2 & 65,7 & 65,9 & 65,8 \\
\hline \multicolumn{6}{|l|}{ Zelfstandigen } \\
\hline Laagopgeleid & Leeftijdsklasse 56-60 & 64,5 & 67,0 & 65,4 & 66,4 \\
\hline Laagopgeleid & Leeftijdsklasse 61-65 & 68,2 & 68,0 & 66,6 & 66,7 \\
\hline Middelbaar opgeleid & Leeftijdsklasse 56-60 & 66,6 & 65,8 & 65,8 & 66,4 \\
\hline Middelbaar opgeleid & Leeftijdsklasse 61-65 & 69,8 & 68,3 & 67,6 & 67,2 \\
\hline Hoogopgeleid & Leeftijdsklasse 56-60 & 67,4 & 66,7 & 67,2 & 67,3 \\
\hline Hoogopgeleid & Leeftijdsklasse 61-65 & 69,7 & 68,8 & 68,7 & 68,4 \\
\hline \multicolumn{6}{|c|}{ Gemiddelde leeftijd waar tot mensen in staat zijn om te werken } \\
\hline \multicolumn{6}{|l|}{ Werknemers } \\
\hline Laagopgeleid & Leeftijdsklasse 56-60 & 64,0 & 64,7 & 64,0 & 64,0 \\
\hline Laagopgeleid & Leeftijdsklasse 61-65 & 65,6 & 66,1 & 65,9 & 65,6 \\
\hline Middelbaar opgeleid & Leeftijdsklasse $56-60$ & 64,2 & 64,8 & 64,5 & 64,4 \\
\hline Middelbaar opgeleid & Leeftijdsklasse 61-65 & 66,1 & 66,1 & 66,0 & 66,1 \\
\hline Hoogopgeleid & Leeftijdsklasse 56-60 & 65,2 & 65,8 & 65,8 & 65,7 \\
\hline Hoogopgeleid & Leeftijdsklasse 61-65 & 66,7 & 66,7 & 66,7 & 66,6 \\
\hline \multicolumn{6}{|l|}{ Zelfstandigen } \\
\hline Laagopgeleid & Leeftijdsklasse 56-60 & 65,6 & 68,1 & 66,2 & 67,3 \\
\hline Laagopgeleid & Leeftijdsklasse 61-65 & 69,5 & 68,5 & 67,8 & 66,3 \\
\hline Middelbaar opgeleid & Leeftijdsklasse 56-60 & 67,5 & 66,3 & 66,6 & 67,1 \\
\hline Middelbaar opgeleid & Leeftijdsklasse 61-65 & 69,6 & 68,6 & 68,5 & 68,8 \\
\hline Hoogopgeleid & Leeftijdsklasse 56-60 & 68,5 & 68,5 & 67,7 & 69,0 \\
\hline Hoogopgeleid & Leeftijdsklasse 61-65 & 71,1 & 71,3 & 70,3 & 70,4 \\
\hline
\end{tabular}

Bron: CBS Microdata (NEA). Bewerking door ROA 


\section{Tabel A2}

Gemiddelde pensioenleeftijd

\begin{tabular}{|c|c|c|c|c|c|c|c|c|c|c|}
\hline Jaar & 2010 & 2011 & 2012 & 2013 & 2014 & 2015 & 2016 & 2017 & 2018 & 2019 \\
\hline $\begin{array}{l}\text { Gemiddelde pensioenleeftijd } \\
\text { zelfstandigen }\end{array}$ & 65,0 & 64,9 & 65,3 & 65,4 & 65,4 & 65,7 & 66,0 & 66,0 & 66,8 & 67,3 \\
\hline $\begin{array}{l}\text { Gemiddelde pensioenleeftijd } \\
\text { werknemers }\end{array}$ & 62,6 & 63,1 & 63,4 & 63,6 & 63,5 & 63,9 & 64,0 & 64,5 & 64,7 & 64,7 \\
\hline
\end{tabular}

Tabel A3.1

Stromen van werk naar WW/bijstand en WIA/ZW (\%)

\begin{tabular}{|c|c|c|c|c|c|c|c|c|c|}
\hline Jaar & 2011 & 2012 & 2013 & 2014 & 2015 & 2016 & 2017 & 2018 & 2019 \\
\hline \multicolumn{10}{|c|}{ Van werk naar WW/bijstand } \\
\hline 56-60 jarigen & 2,1 & 2,8 & 3,3 & 2,8 & 2,7 & 2,2 & 1,6 & 1,3 & 1,3 \\
\hline 64 jaar & 2,0 & 2,5 & 2,9 & 3,5 & 4,0 & 3,3 & 2,6 & 2,1 & 1,9 \\
\hline 65 jaar & 0,0 & 0,1 & 1,9 & 2,0 & 3,6 & 3,3 & 2,7 & 2,6 & 2,4 \\
\hline 66 jaar & 0,0 & 0,1 & 0,0 & 0,0 & 0,0 & 0,0 & 0,1 & 0,2 & 1,4 \\
\hline \multicolumn{10}{|c|}{ Van werk naar WIA/ZW } \\
\hline 56-60 jarigen & 1,1 & 1,0 & 1,0 & 0,9 & 0,9 & 0,9 & 0,9 & 0,9 & 0,9 \\
\hline 64 jaar & 1,1 & 1,0 & 1,0 & 1,0 & 1,1 & 1,2 & 1,3 & 1,3 & 1,3 \\
\hline 65 jaar & 0,0 & 0,0 & 1,1 & 1,1 & 0,9 & 1,2 & 1,1 & 1,3 & 1,3 \\
\hline 66 jaar & 0,0 & 0,0 & 0,0 & 0,0 & 0,0 & 0,0 & 0,0 & 0,1 & 0,6 \\
\hline
\end{tabular}

Bron: CBS Microdata. Bewerking door ROA

\section{Tabel A3.2}

Stromen van WW naar werk (\%)

\begin{tabular}{|l|r|r|r|r|r|r|r|r|r|}
\hline Jaar & 2011 & 2012 & 2013 & 2014 & 2015 & 2016 & 2017 & 2018 & 2019 \\
\hline $56-60$ jarigen & 21,6 & 20,1 & 17,9 & 20,2 & 24,3 & 27,3 & 31,7 & 35,1 & 38,6 \\
\hline 64 jaar & 4,0 & 3,6 & 3,9 & 3,9 & 4,6 & 5,5 & 6,7 & 8,2 & 9,4 \\
\hline 65 jaar & 2,1 & 1,4 & 1,4 & 1,6 & 1,8 & 2,6 & 3,6 & 4,3 & 5,5 \\
\hline 66 jaar & 1,7 & 0,0 & 2,4 & 2,7 & 2,0 & 1,2 & 1,4 & 1,3 & 2,0 \\
\hline
\end{tabular}

Bron: CBS Microdata. Bewerking door ROA 


\section{Tabel A3.3}

Stroom van WW naar werk, naar opleiding (\%)

\begin{tabular}{|c|c|c|c|c|c|c|c|c|c|}
\hline Jaar & 2011 & 2012 & 2013 & 2014 & 2015 & 2016 & 2017 & 2018 & 2019 \\
\hline \multicolumn{10}{|l|}{ 55-60 jaar } \\
\hline Laagopgeleid & 18,6 & 16,6 & 13,9 & 16,1 & 19,7 & 22,0 & 27,5 & 30,8 & 35,5 \\
\hline Middelbaar opgeleid & 24,3 & 21,3 & 19,1 & 21,3 & 26,1 & 29,0 & 33,4 & 37,4 & 40,3 \\
\hline Hoogopgeleid & 23,7 & 22,9 & 21,3 & 23,6 & 26,8 & 30,3 & 33,4 & 36,6 & 39,9 \\
\hline Onbekend & 20,2 & 20,2 & 4,9 & 5,5 & 8,9 & 11,4 & 24,0 & 19,9 & 28,3 \\
\hline \multicolumn{10}{|l|}{64 jaar } \\
\hline Laagopgeleid & 3,4 & 3,0 & 3,2 & 3,1 & 3,7 & 4,3 & 6,3 & 7,5 & 10,2 \\
\hline Middelbaar opgeleid & 3,4 & 3,6 & 4,0 & 4,2 & 5,0 & 6,4 & 7,6 & 9,4 & 10,9 \\
\hline Hoogopgeleid & 8,0 & 4,3 & 5,9 & 4,4 & 5,8 & 5,9 & 6,4 & 8,2 & 8,9 \\
\hline Onbekend & 3,5 & 3,8 & 1,3 & 4,7 & 1,9 & 2,7 & 2,1 & 2,6 & 3,1 \\
\hline \multicolumn{10}{|l|}{65 jaar } \\
\hline Laagopgeleid & 0,9 & 0,8 & 0,9 & 1,3 & 1,5 & 1,8 & 2,9 & 3,6 & 5,4 \\
\hline Middelbaar opgeleid & 2,6 & 2,0 & 1,8 & 1,5 & 1,8 & 2,9 & 3,9 & 5,1 & 6,5 \\
\hline Hoogopgeleid & 4,2 & 2,2 & 1,6 & 2,2 & 2,2 & 3,2 & 3,9 & 4,3 & 5,5 \\
\hline Onbekend & 1,9 & 1,2 & 1,1 & 2,2 & 1,5 & 2,1 & 2,4 & 2,0 & 2,0 \\
\hline \multicolumn{10}{|l|}{66 jaar } \\
\hline Laagopgeleid & $x$ & $x$ & 3,2 & 2,5 & 2,3 & 1,2 & 1,1 & 1,6 & 2,2 \\
\hline Middelbaar opgeleid & $x$ & $x$ & 8,0 & 3,8 & 1,2 & 1,0 & 1,5 & 1,4 & 2,2 \\
\hline Hoogopgeleid & 6,7 & 0,0 & 0,0 & 0,0 & 1,5 & 1,8 & 1,5 & 1,1 & 2,0 \\
\hline Onbekend & 0,0 & 0,0 & 0,0 & 5,1 & 4,5 & 0,5 & 1,0 & 0,7 & 1,1 \\
\hline
\end{tabular}

Bron: CBS Microdata. Bewerking door ROA

x: Onderliggende aantallen zijn kleiner dan 10 en kunnen volgens de richtlijnen van CBS Microdata niet gepubliceerd worden. 
Tabel A3.4

Stroom van werk naar ww/bijstand, naar opleiding (\%)

\begin{tabular}{|c|c|c|c|c|c|c|c|c|c|}
\hline Jaar & 2011 & 2012 & 2013 & 2014 & 2015 & 2016 & 2017 & 2018 & 2019 \\
\hline \multicolumn{10}{|l|}{ 55-60 jaar } \\
\hline Laagopgeleid & 5,8 & 7,0 & 8,0 & 6,7 & 6,2 & 4,7 & 3,1 & 2,4 & 2,2 \\
\hline Middelbaar opgeleid & 5,6 & 6,9 & 8,5 & 7,1 & 6,4 & 4,5 & 2,9 & 2,2 & 2,0 \\
\hline Hoogopgeleid & 3,3 & 3,9 & 6,6 & 5,8 & 5,9 & 4,5 & 3,4 & 2,9 & 2,6 \\
\hline Onbekend & 0,8 & 1,1 & 0,3 & 0,2 & 0,2 & 0,2 & 0,2 & 0,2 & 0,2 \\
\hline \multicolumn{10}{|l|}{64 jaar } \\
\hline Laagopgeleid & 6,5 & 7,1 & 8,8 & 10,7 & 10,3 & 8,4 & 5,0 & 4,5 & 3,6 \\
\hline Middelbaar opgeleid & 7,1 & 7,3 & 10,2 & 10,8 & 10,2 & 8,7 & 6,0 & 4,1 & 3,8 \\
\hline Hoogopgeleid & 3,1 & 4,1 & 6,2 & 8,2 & 8,6 & 7,7 & 6,4 & 5,1 & 4,0 \\
\hline Onbekend & 0,8 & 1,0 & 0,5 & 0,7 & 1,1 & 0,5 & 0,6 & 0,4 & 0,5 \\
\hline \multicolumn{10}{|l|}{65 jaar } \\
\hline Laagopgeleid & 0,0 & 0,2 & 8,6 & 6,4 & 10,0 & 7,6 & 5,2 & 5,2 & 4,7 \\
\hline Middelbaar opgeleid & 0,0 & 0,2 & 4,4 & 5,2 & 7,9 & 7,8 & 5,9 & 5,2 & 4,6 \\
\hline Hoogopgeleid & 0,1 & 0,2 & 2,9 & 4,6 & 7,5 & 7,0 & 5,3 & 5,5 & 4,9 \\
\hline Onbekend & 0,0 & 0,0 & 0,5 & 0,5 & 1,4 & 1,2 & 1,1 & 0,9 & 0,8 \\
\hline \multicolumn{10}{|l|}{66 jaar } \\
\hline Laagopgeleid & 0,6 & 0,0 & 0,0 & 0,0 & 0,1 & 0,0 & 0,2 & 0,3 & 2,7 \\
\hline Middelbaar opgeleid & 0,0 & 0,4 & 0,0 & 0,0 & 0,0 & 0,0 & 0,1 & 0,3 & 2,5 \\
\hline Hoogopgeleid & 0,0 & 0,0 & 0,0 & 0,0 & 0,3 & 0,0 & 0,1 & 0,3 & 2,4 \\
\hline Onbekend & 0,0 & 0,0 & 0,0 & 0,0 & 0,0 & 0,0 & 0,0 & 0,1 & 0,6 \\
\hline
\end{tabular}

Bron: CBS Microdata. Bewerking door ROA 
Tabel A3.5

Stroom van werk naar ZW, naar opleiding (\%)

\begin{tabular}{|c|c|c|c|c|c|c|c|c|c|}
\hline & 2011 & 2012 & 2013 & 2014 & 2015 & 2016 & 2017 & 2018 & 2019 \\
\hline \multicolumn{10}{|l|}{ 55-60 jaar } \\
\hline Laagopgeleid & 2,4 & 2,3 & 2,6 & 2,3 & 2,2 & 2,0 & 1,9 & 1,8 & 2,0 \\
\hline Middelbaar opgeleid & 1,4 & 1,4 & 1,5 & 1,4 & 1,4 & 1,3 & 1,2 & 1,2 & 1,3 \\
\hline Hoogopgeleid & 0,8 & 0,7 & 0,9 & 0,8 & 0,7 & 0,7 & 0,7 & 0,7 & 0,7 \\
\hline Onbekend & 0,9 & 0,8 & 0,6 & 0,6 & 0,5 & 0,6 & 0,5 & 0,5 & 0,5 \\
\hline \multicolumn{10}{|l|}{64 jaar } \\
\hline Laagopgeleid & 2,6 & 2,0 & 2,6 & 2,1 & 2,5 & 2,5 & 2,5 & 2,4 & 2,7 \\
\hline Middelbaar opgeleid & 1,3 & 1,4 & 1,6 & 1,8 & 1,7 & 1,9 & 1,9 & 2,0 & 1,9 \\
\hline Hoogopgeleid & 0,7 & 0,7 & 0,7 & 0,8 & 0,9 & 1,0 & 1,0 & 1,1 & 0,9 \\
\hline Onbekend & 0,9 & 0,9 & 0,7 & 0,8 & 0,8 & 0,9 & 0,9 & 1,0 & 0,9 \\
\hline \multicolumn{10}{|l|}{65 jaar } \\
\hline Laagopgeleid & 0,0 & 0,2 & 1,7 & 2,4 & 1,8 & 2,3 & 1,9 & 2,2 & 2,4 \\
\hline Middelbaar opgeleid & 0,0 & 0,0 & 0,4 & 0,9 & 1,1 & 1,8 & 1,7 & 1,8 & 1,9 \\
\hline Hoogopgeleid & 0,0 & 0,1 & 1,0 & 0,8 & 0,7 & 0,5 & 1,0 & 1,1 & 1,0 \\
\hline Onbekend & 0,0 & 0,0 & 1,2 & 1,0 & 0,8 & 0,9 & 0,8 & 1,1 & 1,0 \\
\hline \multicolumn{10}{|l|}{66 jaar } \\
\hline Laagopgeleid & 0,0 & 0,0 & 0,0 & 0,0 & 0,0 & 0,0 & 0,0 & 0,1 & 1,0 \\
\hline Middelbaar opgeleid & 0,0 & 0,0 & 0,0 & 0,0 & 0,0 & 0,0 & 0,0 & 0,1 & 1,0 \\
\hline Hoogopgeleid & 0,0 & 0,0 & 0,0 & 0,0 & 0,0 & 0,0 & 0,0 & 0,0 & 0,5 \\
\hline Onbekend & 0,0 & 0,0 & 0,0 & 0,0 & 0,0 & 0,0 & 0,0 & 0,1 & 0,5 \\
\hline
\end{tabular}

Bron: CBS Microdata. Bewerking door ROA 
Tabel A3.6

Stroom van werk naar ww/bijstand, naar inkomensklasse (\%)

\begin{tabular}{|c|c|c|c|c|c|c|c|c|c|}
\hline & 2011 & 2012 & 2013 & 2014 & 2015 & 2016 & 2017 & 2018 & 2019 \\
\hline \multicolumn{10}{|l|}{ 55-60 jaar } \\
\hline o tot minimum & 3,1 & 3,9 & 4,8 & 4,3 & 4,8 & 4,2 & 2,8 & 2,3 & 2,3 \\
\hline minimum tot modaal & 3,3 & 4,4 & 5,2 & 4,4 & 3,9 & 3,1 & 2,1 & 1,7 & 1,7 \\
\hline modaal tot $2 \times$ modaal & 1,9 & 2,6 & 3,1 & 2,3 & 1,8 & 1,4 & 1,0 & 0,9 & 0,9 \\
\hline $2 \times$ modaal of hoger & 1,3 & 1,6 & 2,0 & 2,2 & 2,6 & 2,0 & 1,8 & 1,4 & 1,3 \\
\hline \multicolumn{10}{|l|}{64 jaar } \\
\hline o tot minimum & 2,6 & 3,2 & 3,6 & 3,4 & 5,3 & 5,0 & 2,7 & 2,8 & 2,7 \\
\hline minimum tot modaal & 3,4 & 4,7 & 4,8 & 5,2 & 5,5 & 4,5 & 3,1 & 2,7 & 2,4 \\
\hline modaal tot $2 \times$ modaal & 1,8 & 2,2 & 2,9 & 3,5 & 3,3 & 2,6 & 1,9 & 1,5 & 1,3 \\
\hline $2 \times$ modaal of hoger & 0,9 & 1,1 & 1,2 & 2,7 & 3,6 & 3,1 & 3,4 & 2,6 & 2,3 \\
\hline \multicolumn{10}{|l|}{65 jaar } \\
\hline 0 tot minimum & 0,1 & 0,2 & 1,0 & 1,3 & 2,2 & 2,8 & 2,0 & 3,1 & 2,8 \\
\hline minimum tot modaal & 0,0 & 0,0 & 1,7 & 1,8 & 3,0 & 3,1 & 2,3 & 3,4 & 2,9 \\
\hline modaal tot $2 \times$ modaal & 0,0 & 0,1 & 1,2 & 1,1 & 1,7 & 1,3 & 1,4 & 2,2 & 1,9 \\
\hline $2 \times$ modaal of hoger & 0,0 & 0,1 & 0,3 & 0,4 & 1,2 & 1,3 & 1,3 & 2,6 & 2,9 \\
\hline \multicolumn{10}{|l|}{66 jaar } \\
\hline o tot minimum & 0,5 & 0,7 & 0,0 & 0,0 & 0,2 & 0,0 & 0,4 & 0,6 & 1,3 \\
\hline minimum tot modaal & 0,0 & 0,1 & 0,1 & 0,0 & 0,0 & 0,0 & 0,1 & 0,2 & 0,9 \\
\hline modaal tot $2 \times$ modaal & 0,0 & 0,0 & 0,0 & 0,0 & 0,0 & 0,0 & 0,0 & 0,1 & 0,6 \\
\hline $2 \mathrm{x}$ modaal of hoger & 0,0 & 0,0 & 0,0 & 0,1 & 0,0 & 0,0 & 0,0 & 0,1 & 0,6 \\
\hline
\end{tabular}

Bron: CBS Microdata. Bewerking door ROA 
Tabel A3.7

Stroom van werk naar ZW, naar inkomensklasse (\%)

\begin{tabular}{|c|c|c|c|c|c|c|c|c|c|}
\hline & 2011 & 2012 & 2013 & 2014 & 2015 & 2016 & 2017 & 2018 & 2019 \\
\hline \multicolumn{10}{|l|}{ 55-60 jaar } \\
\hline o tot minimum & 1,6 & 1,5 & 1,4 & 1,4 & 1,5 & 1,5 & 1,6 & 1,6 & 1,6 \\
\hline minimum tot modaal & 2,2 & 2,1 & 2,0 & 1,9 & 1,8 & 1,7 & 1,7 & 1,7 & 1,6 \\
\hline modaal tot $2 \times$ modaal & 0,9 & 0,9 & 1,0 & 0,9 & 0,8 & 0,8 & 0,7 & 0,7 & 0,7 \\
\hline $2 \times$ modaal of hoger & 0,3 & 0,2 & 0,3 & 0,3 & 0,3 & 0,3 & 0,4 & 0,3 & 0,4 \\
\hline \multicolumn{10}{|l|}{64 jaar } \\
\hline o tot minimum & 1,2 & 1,2 & 1,1 & 1,3 & 1,4 & 1,7 & 1,5 & 1,8 & 1,4 \\
\hline minimum tot modaal & 2,4 & 2,3 & 2,2 & 2,1 & 2,0 & 2,4 & 2,3 & 2,3 & 2,2 \\
\hline modaal tot $2 \times$ modaal & 0,9 & 1,0 & 0,9 & 1,0 & 1,1 & 1,1 & 1,2 & 1,3 & 1,2 \\
\hline $2 \times$ modaal of hoger & 0,2 & 0,2 & 0,2 & 0,2 & 0,4 & 0,6 & 0,7 & 0,7 & 0,9 \\
\hline \multicolumn{10}{|l|}{65 jaar } \\
\hline o tot minimum & 0,0 & 0,1 & 0,2 & 0,3 & 0,6 & 0,8 & 0,7 & 1,6 & 1,5 \\
\hline minimum tot modaal & 0,0 & 0,1 & 1,5 & 0,7 & 1,1 & 1,1 & 1,1 & 2,3 & 2,0 \\
\hline modaal tot $2 \times$ modaal & 0,0 & 0,0 & 0,6 & 0,9 & 0,4 & 0,6 & 0,6 & 1,4 & 1,2 \\
\hline $2 \mathrm{x}$ modaal of hoger & 0,0 & 0,0 & 0,2 & 0,2 & 0,1 & 0,2 & 0,2 & 0,5 & 0,9 \\
\hline \multicolumn{10}{|l|}{66 jaar } \\
\hline o tot minimum & 0,0 & 0,0 & 0,0 & 0,0 & 0,0 & 0,0 & 0,0 & 0,0 & 0,4 \\
\hline minimum tot modaal & 0,0 & 0,0 & 0,0 & 0,0 & 0,0 & 0,0 & 0,0 & 0,1 & 0,5 \\
\hline modaal tot $2 \times$ modaal & 0,0 & 0,0 & 0,0 & 0,0 & 0,0 & 0,0 & 0,0 & 0,0 & 0,3 \\
\hline $2 \times$ modaal of hoger & 0,0 & 0,0 & 0,0 & 0,0 & 0,0 & 0,0 & 0,0 & 0,1 & 0,2 \\
\hline
\end{tabular}

Bron: CBS Microdata. Bewerking door ROA 
Tabel A4

Scholing (\%)

\begin{tabular}{|c|c|c|c|c|c|c|c|c|c|c|}
\hline Jaar & 2009 & 2010 & 2011 & 2012 & 2013 & 2014 & 2015 & 2016 & 2017 & 2018 \\
\hline \multicolumn{11}{|l|}{ Leeftijdsklasse 56-60 } \\
\hline Cursus betaald door werkgever & 4,7 & 5,2 & 6,5 & 5,6 & 8,1 & 9,4 & 10,3 & 10,4 & 9,9 & 9,2 \\
\hline Cursus niet betaald door werkgever & 1,4 & 1,4 & 1,7 & 1,2 & 1,9 & 2,3 & 2,8 & 2,8 & 2,3 & 2,8 \\
\hline Totaal & 6,1 & 6,6 & 8,1 & 6,8 & 10,0 & 11,7 & 13,1 & 13,2 & 12,2 & 12,0 \\
\hline \multicolumn{11}{|l|}{ Leeftijdsklasse 61-65 } \\
\hline Cursus betaald door werkgever & 1,4 & 1,7 & 1,5 & 0,9 & 2,2 & 2,1 & 2,7 & 2,5 & 2,2 & 2,3 \\
\hline Cursus niet betaald door werkgever & 2,3 & 3,2 & 3,6 & 3,4 & 5,7 & 6,6 & 7,8 & 7,3 & 7,9 & 7,2 \\
\hline Totaal & 3,7 & 4,9 & 5,1 & 4,3 & 7,9 & 8,6 & 10,5 & 9,7 & 10,1 & 9,6 \\
\hline
\end{tabular}

Bron: CBS Microdata. Bewerking door ROA

\section{Tabel A5}

Scholing naar opleidingsniveau (\%)

\begin{tabular}{|c|c|c|c|c|c|c|c|c|c|c|}
\hline Jaar & 2009 & 2010 & 2011 & 2012 & 2013 & 2014 & 2015 & 2016 & 2017 & 2018 \\
\hline \multicolumn{11}{|l|}{ Leeftijdsklasse $56-60$} \\
\hline Laagopgeleid & 3,6 & 3,5 & 5,1 & 3,5 & 5,6 & 8,3 & 7,4 & 7,0 & 7,2 & 8,2 \\
\hline Middelbaar opgeleid & 5,8 & 7,2 & 8,5 & 7,4 & 10,9 & 11,3 & 13,3 & 13,6 & 12,2 & 11,4 \\
\hline Hoogopgeleid & 8,7 & 8,8 & 10,6 & 8,9 & 12,5 & 15,1 & 17,6 & 18,1 & 16,0 & 15,5 \\
\hline \multicolumn{11}{|l|}{ Leeftijdsklasse 61-65 } \\
\hline Laagopgeleid & 1,9 & 2,6 & 3,3 & 2,9 & 3,5 & 5,5 & 6,0 & 6,1 & 6,4 & 5,3 \\
\hline Middelbaar opgeleid & 3,3 & 4,3 & 5,3 & 3,8 & 8,4 & 8,1 & 9,7 & 9,0 & 11,4 & 9,6 \\
\hline Hoogopgeleid & 5,9 & 7,6 & 6,8 & 6,0 & 11,4 & 12,2 & 15,6 & 14,3 & 12,1 & 13,3 \\
\hline
\end{tabular}

Bron: CBS Microdata. Bewerking door ROA 


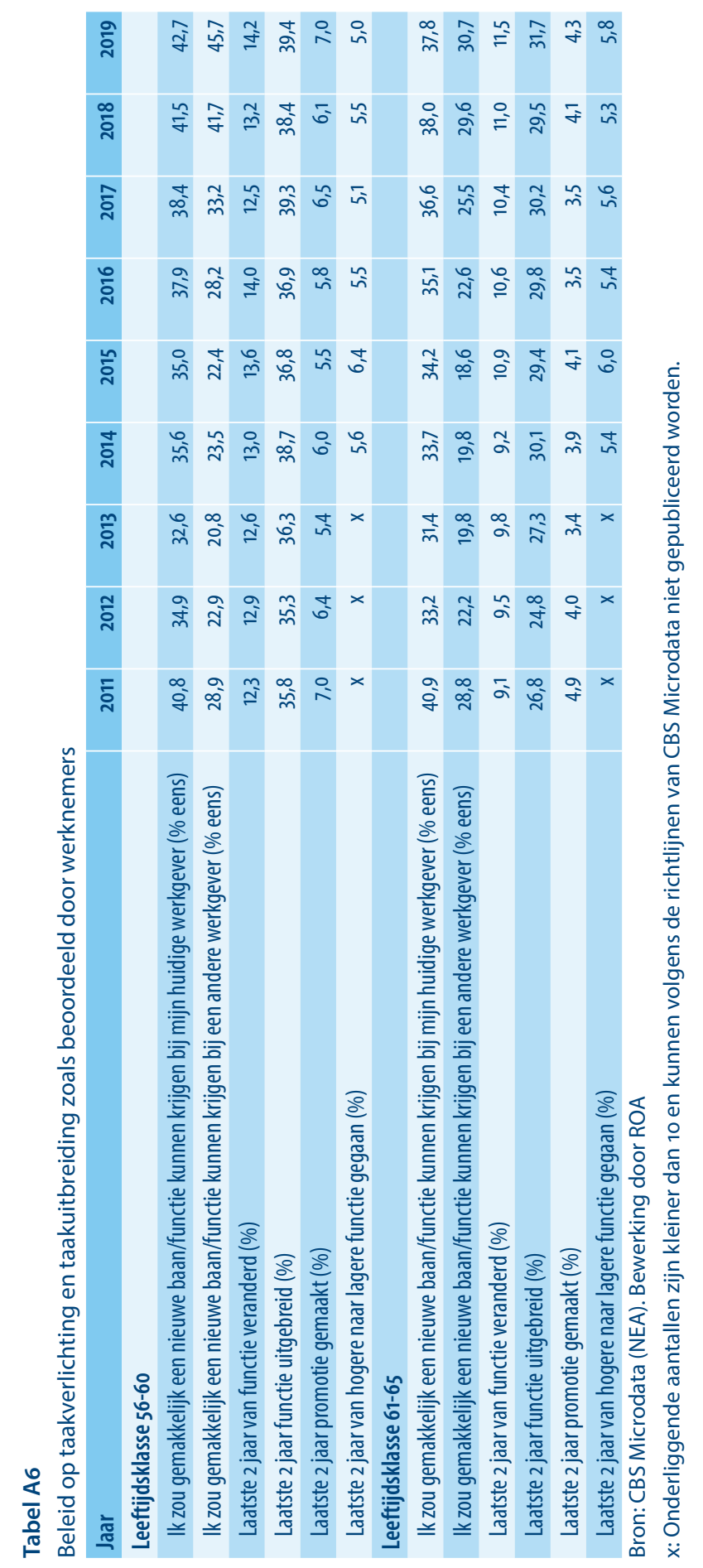


Tabel A7

Inkomensbron (\%)

\begin{tabular}{|c|c|c|c|c|c|c|c|c|c|c|}
\hline & & 2011 & 2012 & 2013 & 2014 & 2015 & 2016 & 2017 & 2018 & 2019 \\
\hline \multirow[t]{6}{*}{64 jaar } & Loondienst/eigen onderneming & 18,9 & 20,8 & 23,1 & 32,9 & 35,4 & 38,3 & 41,6 & 45,0 & 48,3 \\
\hline & Bijstand/WW & 4,9 & 5,1 & 5,4 & 7,7 & 8,5 & 8,7 & 8,4 & 7,8 & 7,0 \\
\hline & ZW/WIA & 13,1 & 12,5 & 12,2 & 12,9 & 12,9 & 13,1 & 12,9 & 12,8 & 12,6 \\
\hline & AOW/pensioen & 42,6 & 41,8 & 40,2 & 26,6 & 23,5 & 21,1 & 20,0 & 17,9 & 16,4 \\
\hline & Overig inkomen & 2,4 & 2,5 & 2,7 & 3,1 & 3,2 & 3,3 & 3,1 & 3,3 & 3,5 \\
\hline & Geen inkomen & 18,0 & 17,1 & 16,3 & 16,8 & 16,5 & 15,4 & 14,1 & 13,1 & 12,2 \\
\hline \multirow[t]{6}{*}{65 jaar } & Loondienst/eigen onderneming & 6,0 & 6,3 & 7,0 & 8,7 & 14,7 & 21,2 & 28,6 & 35,9 & 39,2 \\
\hline & Bijstand/WW & 0,2 & 0,3 & 0,7 & 1,1 & 2,4 & 4,5 & 6,6 & 7,9 & 7,2 \\
\hline & ZW/WIA & 0,0 & 0,4 & 1,2 & 2,1 & 3,4 & 6,7 & 10,3 & 13,1 & 13,1 \\
\hline & AOW/pensioen & 93,2 & 92,4 & 89,5 & 84,9 & 74,3 & 57,6 & 40,6 & 25,9 & 24,1 \\
\hline & Overig inkomen & 0,4 & 0,5 & 0,6 & 0,9 & 1,2 & 2,0 & 2,7 & 3,6 & 3,8 \\
\hline & Geen inkomen & 0,2 & 0,2 & 1,0 & 2,3 & 4,0 & 7,9 & 11,2 & 13,5 & 12,6 \\
\hline \multirow[t]{6}{*}{66 jaar } & Loondienst/eigen onderneming & 4,7 & 4,9 & 4,8 & 5,0 & 5,3 & 6,9 & 7,6 & 10,0 & 18,6 \\
\hline & Bijstand/WW & 0,1 & 0,1 & 0,1 & 0,1 & 0,1 & 0,2 & 0,7 & 1,1 & 3,1 \\
\hline & ZW/WIA & 0,0 & 0,0 & 0,0 & 0,0 & 0,0 & 0,0 & 0,0 & 0,5 & 4,6 \\
\hline & A0W/pensioen & 94,6 & 94,6 & 94,6 & 94,5 & 94,1 & 92,5 & 91,4 & 87,8 & 67,7 \\
\hline & Overig inkomen & 0,4 & 0,4 & 0,4 & 0,4 & 0,3 & 0,3 & 0,1 & 0,3 & 1,7 \\
\hline & Geen inkomen & 0,1 & 0,1 & 0,1 & 0,1 & 0,1 & 0,2 & 0,2 & 0,2 & 4,3 \\
\hline
\end{tabular}

Bron: CBS Microdata. Bewerking door ROA 
Tabel A7.2

Inkomensbron naar opleiding (\%)

\begin{tabular}{|c|c|c|c|c|c|c|c|c|c|c|}
\hline & & 2011 & 2012 & 2013 & 2014 & 2015 & 2016 & 2017 & 2018 & 2019 \\
\hline \multicolumn{11}{|l|}{64 jaar } \\
\hline \multirow[t]{6}{*}{ Laagopgeleid } & $\begin{array}{l}\text { Loondienst /eigen } \\
\text { onderneming }\end{array}$ & 13,6 & 14,8 & 17,0 & 25,3 & 26,9 & 29,8 & 33,1 & 36,3 & 37,7 \\
\hline & Bijstand/WW & 6,0 & 6,4 & 7,6 & 10,2 & 11,0 & 12,0 & 11,1 & 10,7 & 10,4 \\
\hline & ZW/WIA & 16,5 & 16,1 & 15,1 & 16,2 & 16,8 & 17,4 & 16,9 & 16,8 & 16,9 \\
\hline & AOW/pensioen & 33,6 & 32,6 & 33,0 & 21,2 & 18,5 & 16,6 & 15,0 & 13,1 & 12,3 \\
\hline & Overig inkomen & 2,2 & 2,6 & 3,1 & 3,3 & 3,4 & 3,2 & 3,4 & 3,5 & 4,2 \\
\hline & Geen inkomen & 28,0 & 27,5 & 24,1 & 23,9 & 23,4 & 20,9 & 20,5 & 19,6 & 18,4 \\
\hline \multirow[t]{6}{*}{$\begin{array}{l}\text { Middelbaar } \\
\text { opgeleid }\end{array}$} & $\begin{array}{l}\text { Loondienst /eigen } \\
\text { onderneming }\end{array}$ & 18,6 & 21,8 & 23,4 & 35,9 & 37,8 & 41,6 & 44,3 & 48,4 & 51,0 \\
\hline & Bijstand/WW & 3,5 & 3,8 & 4,2 & 6,1 & 7,1 & 7,1 & 6,5 & 5,4 & 5,0 \\
\hline & ZW/WIA & 13,1 & 12,0 & 12,2 & 12,2 & 12,5 & 12,6 & 12,9 & 12,4 & 12,4 \\
\hline & AOW/pensioen & 45,5 & 43,8 & 43,7 & 29,6 & 25,6 & 21,8 & 20,8 & 18,6 & 16,6 \\
\hline & Overig inkomen & 2,1 & 2,3 & 2,3 & 2,9 & 3,0 & 3,1 & 2,8 & 3,1 & 3,1 \\
\hline & Geen inkomen & 17,2 & 16,4 & 14,2 & 13,3 & 14,1 & 13,8 & 12,7 & 12,1 & 12,0 \\
\hline \multirow[t]{6}{*}{ Hoogopgeleid } & $\begin{array}{l}\text { Loondienst /eigen } \\
\text { onderneming }\end{array}$ & 24,5 & 27,3 & 29,5 & 42,0 & 42,2 & 47,1 & 47,5 & 51,1 & 54,3 \\
\hline & Bijstand/WW & 3,1 & 3,3 & 3,1 & 5,3 & 6,7 & 6,7 & 7,1 & 6,6 & 5,5 \\
\hline & ZW/WIA & 9,3 & 9,0 & 7,2 & 8,4 & 8,5 & 7,5 & 8,5 & 7,8 & 7,6 \\
\hline & AOW/pensioen & 52,5 & 49,7 & 50,1 & 33,5 & 30,3 & 26,6 & 26,3 & 23,4 & 22,4 \\
\hline & Overig inkomen & 1,1 & 1,5 & 1,6 & 2,8 & 2,9 & 2,8 & 1,9 & 2,4 & 2,4 \\
\hline & Geen inkomen & 9,4 & 9,1 & 8,5 & 8,0 & 9,5 & 9,3 & 8,7 & 8,7 & 7,6 \\
\hline 65 jaar & & 2011 & 2012 & 2013 & 2014 & 2015 & 2016 & 2017 & 2018 & 2019 \\
\hline \multirow[t]{6}{*}{ Laagopgeleid } & $\begin{array}{l}\text { Loondienst /eigen } \\
\text { onderneming }\end{array}$ & 3,8 & 4,0 & 5,3 & 6,7 & 11,1 & 16,6 & 22,9 & 29,9 & 32,8 \\
\hline & Bijstand/WW & 0,4 & 0,4 & 1,0 & 1,5 & 3,2 & 6,3 & 9,7 & 10,9 & 10,4 \\
\hline & ZW/WIA & 0,0 & 0,6 & 1,5 & 2,6 & 4,0 & 8,6 & 12,7 & 16,6 & 16,5 \\
\hline & AOW/pensioen & 95,6 & 94,7 & 89,9 & 85,1 & 75,3 & 54,7 & 35,8 & 18,8 & 16,8 \\
\hline & Overig inkomen & 0,2 & 0,3 & 0,6 & 0,9 & 1,1 & 1,8 & 2,9 & 3,9 & 3,9 \\
\hline & Geen inkomen & 0,1 & 0,1 & 1,8 & 3,2 & 5,3 & 11,9 & 16,0 & 19,8 & 19,5 \\
\hline \multirow[t]{6}{*}{$\begin{array}{l}\text { Middelbaar } \\
\text { opgeleid }\end{array}$} & $\begin{array}{l}\text { Loondienst /eigen } \\
\text { onderneming }\end{array}$ & 7,2 & 7,1 & 7,4 & 9,6 & 17,1 & 23,7 & 31,7 & 39,1 & 42,5 \\
\hline & Bijstand/WW & 0,1 & 0,2 & 0,4 & 0,8 & 1,8 & 3,5 & 5,0 & 5,8 & 5,0 \\
\hline & ZW/WIA & 0,0 & 0,4 & 1,2 & 2,1 & 3,2 & 6,7 & 9,9 & 13,0 & 12,2 \\
\hline & AOW/pensioen & 92,1 & 91,9 & 89,9 & 84,7 & 73,4 & 56,6 & 40,8 & 26,6 & 25,3 \\
\hline & Overig inkomen & 0,5 & 0,4 & 0,4 & 0,9 & 1,2 & 2,0 & 2,6 & 3,5 & 3,7 \\
\hline & Geen inkomen & 0,1 & 0,1 & 0,8 & 1,8 & 3,3 & 7,5 & 10,0 & 11,9 & 11,3 \\
\hline \multirow[t]{3}{*}{ Hoogopgeleid } & $\begin{array}{l}\text { Loondienst /eigen } \\
\text { onderneming }\end{array}$ & 8,2 & 8,5 & 9,0 & 12,3 & 20,0 & 25,8 & 34,6 & 40,1 & 43,2 \\
\hline & Bijstand/WW & 0,2 & 0,4 & 0,5 & 0,6 & 1,5 & 3,1 & 5,2 & 6,6 & 5,6 \\
\hline & ZW/WIA & 0,0 & 0,3 & 1,1 & 1,3 & 2,6 & 4,2 & 6,1 & 8,5 & 7,9 \\
\hline
\end{tabular}




\begin{tabular}{|c|c|c|c|c|c|c|c|c|c|c|}
\hline & & 2011 & 2012 & 2013 & 2014 & 2015 & 2016 & 2017 & 2018 & 2019 \\
\hline & AOW/pensioen & 91,2 & 90,3 & 88,0 & 84,4 & 72,2 & 60,5 & 45,7 & 34,2 & 33,1 \\
\hline & Overig inkomen & 0,3 & 0,4 & 0,8 & 0,8 & 0,9 & 1,6 & 1,6 & 2,5 & 2,6 \\
\hline & Geen inkomen & 0,1 & 0,1 & 0,7 & 0,7 & 2,7 & 4,9 & 6,9 & 8,0 & 7,6 \\
\hline 66 jaar & & 2011 & 2012 & 2013 & 2014 & 2015 & 2016 & 2017 & 2018 & 2019 \\
\hline \multirow[t]{6}{*}{ Laagopgeleid } & $\begin{array}{l}\text { Loondienst /eigen } \\
\text { onderneming }\end{array}$ & 2,7 & 3,3 & 3,3 & 3,5 & 3,9 & 4,8 & 5,2 & 7,2 & 14,3 \\
\hline & Bijstand/WW & 0,2 & 0,1 & 0,1 & 0,1 & 0,1 & 0,2 & 1,2 & 2,2 & 4,4 \\
\hline & ZW/WIA & 0,0 & 0,0 & 0,0 & 0,0 & 0,0 & 0,0 & 0,0 & 0,6 & 5,7 \\
\hline & AOW/pensioen & 96,8 & 96,5 & 96,3 & 96,1 & 95,7 & 94,6 & 93,3 & 89,3 & 68,0 \\
\hline & Overig inkomen & 0,3 & 0,2 & 0,3 & 0,3 & 0,3 & 0,3 & 0,2 & 0,5 & 1,7 \\
\hline & Geen inkomen & 0,0 & 0,0 & 0,0 & 0,0 & 0,0 & 0,1 & 0,1 & 0,1 & 6,0 \\
\hline \multirow[t]{6}{*}{$\begin{array}{l}\text { Middelbaar } \\
\text { opgeleid }\end{array}$} & $\begin{array}{l}\text { Loondienst /eigen } \\
\text { onderneming }\end{array}$ & 5,0 & 5,9 & 5,4 & 5,6 & 5,6 & 8,1 & 8,9 & 11,8 & 21,6 \\
\hline & Bijstand/WW & 0,1 & 0,1 & 0,0 & 0,0 & 0,0 & 0,0 & 0,2 & 0,6 & 2,0 \\
\hline & ZW/WIA & 0,0 & 0,0 & 0,0 & 0,0 & 0,0 & 0,0 & 0,0 & 0,4 & 4,5 \\
\hline & AOW/pensioen & 94,5 & 93,5 & 94,1 & 94,1 & 94,0 & 91,2 & 90,7 & 86,6 & 66,5 \\
\hline & Overig inkomen & 0,5 & 0,4 & 0,4 & 0,3 & 0,4 & 0,3 & 0,1 & 0,4 & 1,7 \\
\hline & Geen inkomen & 0,0 & 0,0 & 0,1 & 0,0 & 0,0 & 0,4 & 0,1 & 0,3 & 3,7 \\
\hline \multirow[t]{6}{*}{ Hoogopgeleid } & $\begin{array}{l}\text { Loondienst /eigen } \\
\text { onderneming }\end{array}$ & 5,6 & 6,3 & 6,0 & 5,8 & 7,4 & 9,0 & 9,2 & 12,9 & 20,4 \\
\hline & Bijstand/WW & 0,0 & 0,1 & 0,0 & 0,1 & 0,1 & 0,0 & 0,3 & 0,8 & 2,7 \\
\hline & ZW/WIA & 0,0 & 0,0 & 0,0 & 0,0 & 0,0 & 0,0 & 0,0 & 0,3 & 2,9 \\
\hline & AOW/pensioen & 94,0 & 93,2 & 93,5 & 93,2 & 92,1 & 90,1 & 90,2 & 85,5 & 70,2 \\
\hline & Overig inkomen & 0,4 & 0,4 & 0,4 & 0,8 & 0,3 & 0,3 & 0,1 & 0,3 & 1,3 \\
\hline & Geen inkomen & 0,1 & 0,1 & 0,0 & 0,2 & 0,0 & 0,5 & 0,2 & 0,2 & 2,6 \\
\hline
\end{tabular}

Bron: CBS Microdata. Bewerking door ROA

\section{Tabel A8}

Gemiddeld bruto persoonlijk inkomen

\begin{tabular}{|l|r|r|r|r|r|r|r|r|r|r|r|}
\hline & 2009 & 2010 & 2011 & 2012 & 2013 & 2014 & 2015 & 2016 & 2017 & 2018 & 2019 \\
\hline 64-jarigen & 27521 & 28949 & 29800 & 30492 & 31206 & 33496 & 33807 & 35094 & 37621 & 37909 & 39715 \\
\hline 65-jarigen & 27250 & 27485 & 28918 & 29197 & 29491 & 30138 & 30598 & 32230 & 35072 & 35558 & 37678 \\
\hline 66-jarigen & 25214 & 25784 & 25842 & 26843 & 26837 & 27510 & 27616 & 28626 & 31098 & 31110 & 33927 \\
\hline
\end{tabular}

Bron: CBS Microdata. Bewerking door ROA 


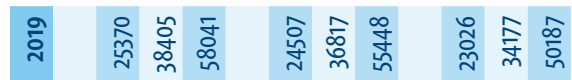

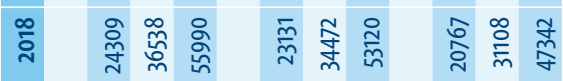

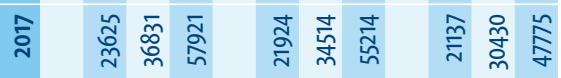

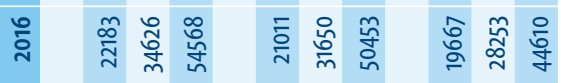

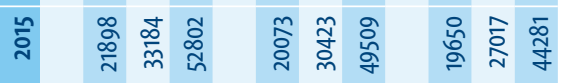

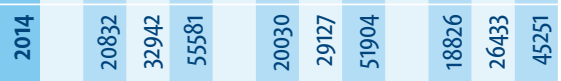

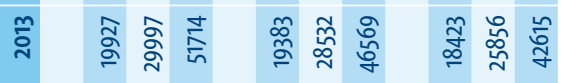

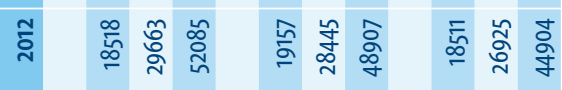

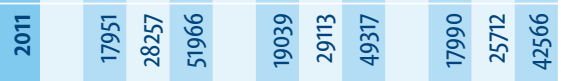

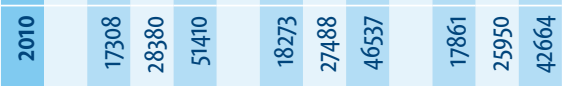

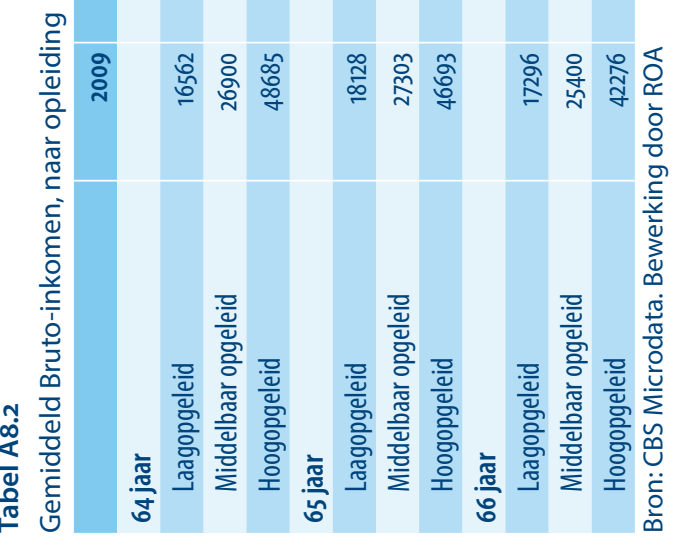


Tabel A9.1

Kunnen voldoen aan eisen werk (\%)

\begin{tabular}{|c|c|c|c|c|}
\hline Jaar & 2012 & 2015 & 2017 & 2019 \\
\hline \multicolumn{5}{|c|}{ Makkelijk kunnen voldoen aan de fysieke eisen van hun werk } \\
\hline \multicolumn{5}{|l|}{ Werknemers } \\
\hline Leeftijdsklasse $56-60$ & 83,3 & 84,8 & 83,0 & 84,9 \\
\hline Leeftijdsklasse 61-65 & 82,6 & 81,8 & 80,5 & 81,4 \\
\hline \multicolumn{5}{|l|}{ Zelfstandigen } \\
\hline Leeftijdsklasse $56-60$ & 82,9 & 81,1 & 78,9 & 81,8 \\
\hline Leeftijdsklasse 61-65 & 84,0 & 79,7 & 74,8 & 80,5 \\
\hline \multicolumn{5}{|c|}{ Makkelijk kunnen voldoen aan de psychische eisen van hun werk } \\
\hline \multicolumn{5}{|l|}{ Werknemers } \\
\hline Leeftijdsklasse 56-60 & 86,9 & 87,3 & 84,9 & 88,6 \\
\hline Leeftijdsklasse 61-65 & 85,8 & 85,8 & 85,5 & 86,5 \\
\hline \multicolumn{5}{|l|}{ Zelfstandigen } \\
\hline Leeftijdsklasse 56-60 & 89,2 & 84,8 & 82,5 & 87,2 \\
\hline Leeftijdsklasse 61-65 & 89,1 & 84,3 & 82,2 & 84,8 \\
\hline
\end{tabular}

Bron: CBS Microdata (NEA). Bewerking door ROA 
Tabel A9.2

Kunnen voldoen aan eisen werk, naar opleiding (\%)

\begin{tabular}{|c|c|c|c|c|c|}
\hline Jaar & & 2012 & 2015 & 2017 & 2019 \\
\hline \multicolumn{6}{|c|}{ Makkelijk kunnen voldoen aan de fysieke eisen van hun werk } \\
\hline \multicolumn{6}{|l|}{ Werknemers } \\
\hline Laagopgeleid & Leeftijdsklasse 56-60 & 78,9 & 80,2 & 75,2 & 78,0 \\
\hline Laagopgeleid & Leeftijdsklasse $61-65$ & 77,4 & 78,0 & 73,7 & 76,6 \\
\hline Middelbaar opgeleid & Leeftijdsklasse 56-60 & 83,0 & 83,8 & 81,6 & 83,7 \\
\hline Middelbaar opgeleid & Leeftijdsklasse 61-65 & 84,4 & 80,7 & 79,3 & 80,2 \\
\hline Hoogopgeleid & Leeftijdsklasse 56-60 & 88,4 & 90,1 & 91,7 & 91,9 \\
\hline Hoogopgeleid & Leeftijdsklasse $61-65$ & 86,9 & 87,5 & 88,8 & 88,9 \\
\hline \multicolumn{6}{|l|}{ Zelfstandigen } \\
\hline Laagopgeleid & Leeftijdsklasse 56-60 & 76,1 & 76,6 & 73,7 & 79,4 \\
\hline Laagopgeleid & Leeftijdsklasse $61-65$ & 80,1 & 71,9 & 73,4 & 72,8 \\
\hline Middelbaar opgeleid & Leeftijdsklasse 56-60 & 79,2 & 78,9 & 76,3 & 77,5 \\
\hline Middelbaar opgeleid & Leeftijdsklasse $61-65$ & 80,5 & 80,2 & 71,0 & 78,1 \\
\hline Hoogopgeleid & Leeftijdsklasse 56-60 & 90,6 & 85,2 & 83,7 & 87,4 \\
\hline Hoogopgeleid & Leeftijdsklasse $61-65$ & 90,4 & 83,8 & 79,6 & 87,3 \\
\hline \multicolumn{6}{|c|}{ Makkelijk kunnen voldoen aan de psychische eisen van hun werk } \\
\hline \multicolumn{6}{|l|}{ Werknemers } \\
\hline Laagopgeleid & Leeftijdsklasse 56-60 & 85,2 & 85,9 & 82,7 & 87,3 \\
\hline Laagopgeleid & Leeftijdsklasse $61-65$ & 83,5 & 85,9 & 83,6 & 86,9 \\
\hline Middelbaar opgeleid & Leeftijdsklasse 56-60 & 88,3 & 88,0 & 86,2 & 89,6 \\
\hline Middelbaar opgeleid & Leeftijdsklasse 61-65 & 86,6 & 87,1 & 86,6 & 87,3 \\
\hline Hoogopgeleid & Leeftijdsklasse 56-60 & 87,4 & 87,8 & 85,4 & 88,9 \\
\hline Hoogopgeleid & Leeftijdsklasse 61-65 & 87,5 & 84,6 & 86,3 & 86,0 \\
\hline \multicolumn{6}{|l|}{ Zelfstandigen } \\
\hline Laagopgeleid & Leeftijdsklasse 56-60 & 89,3 & 86,9 & 79,7 & 88,5 \\
\hline Laagopgeleid & Leeftijdsklasse $61-65$ & 83,5 & 79,3 & 77,5 & 79,3 \\
\hline Middelbaar opgeleid & Leeftijdsklasse 56-60 & 87,4 & 83,9 & 81,9 & 85,1 \\
\hline Middelbaar opgeleid & Leeftijdsklasse $61-65$ & 87,7 & 86,9 & 80,7 & 83,9 \\
\hline Hoogopgeleid & Leeftijdsklasse 56-60 & 90,8 & 84,9 & 84,4 & 89,1 \\
\hline Hoogopgeleid & Leeftijdsklasse $61-65$ & 94,8 & 85,1 & 85,7 & 88,1 \\
\hline
\end{tabular}

Bron: CBS Microdata (NEA). Bewerking door ROA

Tabel A10

Ervaren gezondheid (\%)

\begin{tabular}{|c|c|c|c|c|c|c|c|c|c|c|c|}
\hline & 2010 & 2011 & 2012 & 2013 & 2014 & 2015 & 2016 & 2017 & 2018 & 2019 & 2020 \\
\hline 64-jarigen & 62 & 75 & 63 & 60 & 66 & 61 & 62 & 67 & 61 & 60 & 68 \\
\hline 65-jarigen & 69 & 70 & 65 & 65 & 68 & 70 & 62 & 70 & 69 & 71 & 74 \\
\hline 66-jarigen & 65 & 73 & 64 & 71 & 68 & 75 & 70 & 73 & 71 & 69 & 65 \\
\hline
\end{tabular}

Bron: CBS Microdata. Bewerking door ROA 


\section{Tabel A11}

Gezonde levensverwachting in jaren

\begin{tabular}{|lccccccccccccccc|c|}
\hline Jaar & 2007 & 2008 & 2009 & 2010 & 2011 & 2012 & 2013 & 2014 & 2015 & 2016 & 2017 & 2018 & 2019 & 2020 \\
\hline Levensverwachting in als goed ervaren gezondheid & & & & & & & & & \\
\hline Mannen-60 jaar & 14 & 13,3 & 14,5 & 14,1 & 13,7 & 14 & 14,2 & 14,2 & 14,5 & 14,8 & 15 & 14,5 & 15,1 & 15,7 \\
\hline Mannen-65 jaar & 11,2 & 10,4 & 11,6 & 11,3 & 10,9 & 11,2 & 11,5 & 11,5 & 11,7 & 11,8 & 12,2 & 12 & 12,4 & 12,7 \\
\hline Mannen-70 jaar & 8,6 & 7,6 & 8,9 & 8,7 & 8,3 & 8,6 & 8,9 & 8,5 & 8,8 & 8,8 & 9,2 & 9 & 9,4 & 9,9 \\
\hline Vrouwen-60 jaar & 14,4 & 14,4 & 14 & 14,2 & 14,4 & 14 & 14,4 & 14,9 & 14,9 & 15,5 & 15,7 & 15,2 & 15,4 & 16,6 \\
\hline Vrouwen-65 jaar & 11,5 & 11,4 & 11,2 & 11,1 & 11,3 & 11,2 & 11,6 & 11,9 & 12,2 & 12,7 & 13,2 & 12,6 & 12,4 & 13,4 \\
\hline Vrouwen-70 jaar & 8,7 & 8,5 & 8,4 & 8,3 & 8,4 & 8,6 & 8,5 & 9,2 & 9,2 & 9,9 & 10,3 & 9,7 & 9,6 & 10,5 \\
\hline Levensverwachting in goede geestelijke gezondheid & & & & & & & & & & \\
\hline Mannen-60 jaar & 19,4 & 19,9 & 20,2 & 20 & 20,5 & 20,5 & 20,4 & 20,9 & 21,2 & 21,3 & 21,7 & 20,8 & 21,6 & 20,9 \\
\hline Mannen-65jaar & 15,6 & 16,1 & 16,4 & 16,2 & 16,9 & 16,8 & 16,6 & 17,4 & 17,5 & 17,5 & 17,9 & 17,3 & 17,8 & 17,2 \\
\hline Mannen-70 jaar & 12,3 & 12,5 & 13 & 12,7 & 13,3 & 13,1 & 12,9 & 13,6 & 13,9 & 13,9 & 14,1 & 13,8 & 14 & 13,5 \\
\hline Vrouwen-60 jaar & 21,3 & 21,6 & 21,5 & 21,6 & 21,8 & 22 & 22,1 & 22,5 & 22,3 & 21,9 & 22,1 & 22,1 & 22,6 & 22,2 \\
\hline Vrouwen-65jaar & 17,5 & 17,8 & 17,7 & 17,7 & 18,1 & 18,1 & 18,4 & 18,6 & 18,7 & 18,1 & 18,5 & 18,5 & 18,8 & 18,3 \\
\hline Vrouwen-70 jaar & 14 & 14,1 & 13,7 & 13,9 & 14,6 & 14,5 & 14,7 & 14,9 & 15 & 14,6 & 14,8 & 14,7 & 15 & 14,7 \\
\hline
\end{tabular}

Bron: CBS Microdata. Bewerking door ROA 


\section{Appendix B: Difference in Difference analyses}

Difference in Difference (DiD) is een quasi experimentele techniek die het differentiële effect van een interventie op een 'interventiegroep' versus een 'controlegroep' in een natuurlijk experiment. Op basis van paneldata berekent de DiD-methode het effect van een interventie op een uitkomst door te kijken of de uitkomstmaat voor de interventiegroep zich (gemiddeld) anders ontwikkelt dan voor de controlegroep na de interventie (zie figuur B1).

\section{Figuur B1}

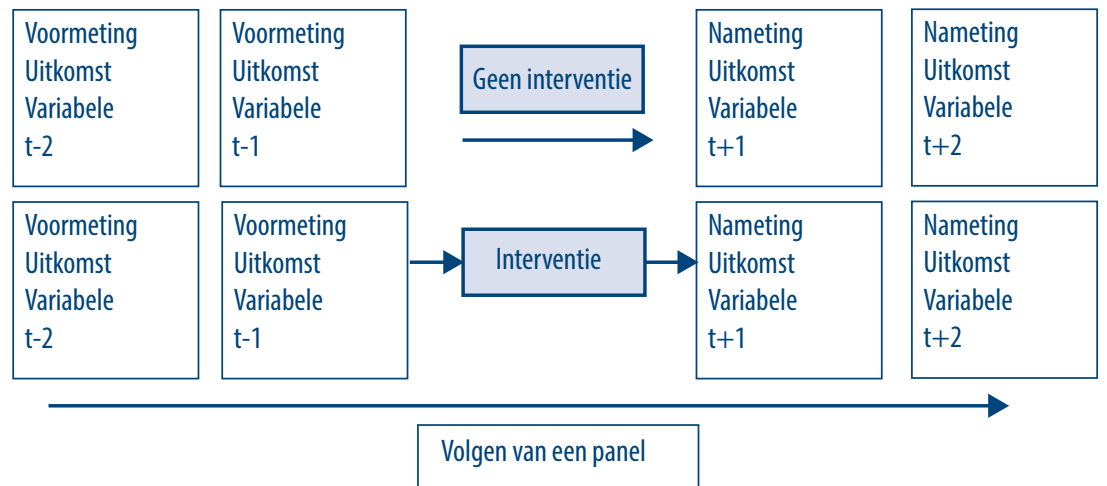

Bron: De Grip, A., Künn, A., \& Montizaan, R. (2019). Raamwerk Evaluatie Interventies Leven Lang Ontwikkelen. ROA. ROA Reports No. 002

https://doi.org/10.26481/umarep.2019002

In dit geval bestaan de interventiegroepen uit de cohorten werknemers die op latere leeftijden met AOW kunnen (in totaal hebben we 7 interventiegroepen). De controlegroep is het cohort dat voor het laatst op 65-jarige leeftijd met pensioen kon gaan. De DiD methode vergelijkt vervolgens in welke mate de pensioenleeftijd zich anders is gaan ontwikkelen van de interventiegroepen op het moment dat werknemers getroffen worden door de verhoging van de AOW-leeftijd. Relevant hierbij om op te merken is dat de methode niet probeert te meten of cohorten van elkaar verschillen. De methode laat verschillen tussen cohorten toe, zolang de trends voor de interventie ongeveer parallel verliepen voor de interventie. De identificatie van het causale effect zit hem vooral in of er sterke veranderingen in de trends waarneembaar zijn na de interventie, waardoor de verschillen tussen de interventiegroep en de controlegroep groter of kleiner worden. 
Omdat de AOW-leeftijdsverhoging gradueel wordt verhoogd, gebruiken wij een methode die specifiek hier rekening mee houdt. Het betreft dezelfde methode als die in de studies van Staubli en Zweimuller (2013), CPB (2019), en Ardito (2021) wordt gebruikt die eveneens onderzoek deden naar de impact van graduele verhogingen van de pensioenleeftijd voor Nederland, Oostenrijk en Italië.

We schatten een model met de volgende modelspecificatie (Logit voor dummy variabelen en OLS voor continue variabelen):

$$
y_{i t}=\gamma_{s(i)}+\lambda_{t}+v_{i t}+\beta\left(D_{\text {stoo }}+D_{\text {stos }}+D_{\text {st10 }}+D_{\text {st15 }}+D_{\text {st20 }}\right)+\varepsilon_{\text {it }}
$$

Waarbij:

$\mathrm{y}_{\mathrm{it}}=$ de afhankelijke variabele

$\gamma_{\mathrm{s}(\mathrm{i})}=$ dummies voor cohort $\mathrm{s}(\mathrm{i})$

$\lambda_{\mathrm{t}}=$ jaardummies

$v_{i t}=$ leeftijddummies

$\mathrm{D}_{\text {stoo }}=$ treatment dummy voor cohort s op tijdstip t. Deze is 1 als de pensioenleeftijd is bereikt, en o anders. (deze meten het treatment effect)

$\mathrm{D}_{\text {stos' }}, \mathrm{D}_{\text {st10 }}, \mathrm{D}_{\text {st15' }} \mathrm{D}_{\text {st2o }}=$ lead treatment dummies voor cohort s op tijdstip t voor $0.5,1,1.5 \mathrm{en}$ 2 jaar voor de treatment (deze meten eventuele anticipatie effecten) $\varepsilon_{i t}=$ De standard errors geclusterd op individu

Bij interacties met subgroepen (opleiding, geslacht, werknemers vs zelfstandig) wordt elke variabele in het model geïnteracteerd met subgroepdummies om te kijken of deze statistisch significant zijn.

We maken een voorspelling op basis van de modelschatting per persoon, en kijken we naar het gemiddelde van de modelschattingen per leeftijdscategorie en per cohort. 


\section{Appendix C: Gebruikte databestanden}

De monitor wordt net zoals de monitor die gepubliceerd is in 2020 gevuld met data die periodiek beschikbaar zijn. Bij het CBS zijn administratieve data jaarlijks beschikbaar op basis van gegevens van de belastingdienst, UWV en gemeenten over werk, inkomstenbron (werk, uitkering, pensioen), hoogte van het inkomen en vermogen. Deze gegevens worden aangevuld met informatie uit enquêtes die jaarlijks worden uitgezet.

In de monitor wordt de periode 2007-2019 in beeld gebracht voor de groep 55-75-jarigen die op 31 december van elk jaar in Nederland wonen. De volgende bestanden zijn gebruikt.

1. Inkomensbronnen (SECMBUS). Dit is een CBS-microdatabestand met per persoon alle inkomensbronnen (loondienst, eigen bedrijf, uitkering) en de belangrijkste inkomensbron. De SECMBUS is beschikbaar voor alle jaren tussen 2007 en 2019.

2. Hoogte van het inkomen. Hiervoor wordt gebruikgemaakt van de CBS-microdatabestanden IPI en INPATAB. Dit bestand bevat onder andere informatie over de hoogte van het inkomen uit arbeid (loon en inkomen als zelfstandige), inkomen uit uitkering (naar type uitkering, waaronder pensioen en lijfrente) en inkomen uit vermogen. Ook bevat het bestand informatie over de koopkracht van personen. IPI is beschikbaar voor de jaren 2007 tot en met 2010. INPATAB is beschikbaar van 2011 tot en met 2019.

3. Enquête beroepsbevolking (EBB). Deze enquête bevat periodieke informatie over beroepen en inkomen. Het geeft een beeld van de koppeling tussen beroep en inkomen op verschillende dimensies, zoals de leeftijdssamenstelling binnen beroepen/beroepsgroepen en de investeringen in scholing. Ook wordt duidelijk wie niet werkt en wat de reden daarvoor is. De EBB is beschikbaar voor alle jaren (20072019)

4. Nederlandse Enquête Arbeidsomstandigheden (NEA). Dit is een enquête van TNO en CBS onder werknemers tussen de 15 en 65 jaar (2003-2013) of tussen de 15 en 75 jaar (vanaf 2014). De vragenlijst bevat onder andere vragen over werktijden, werkdruk, emotionele en fysieke werkbelasting, gezondheid, chronische ziekten, functioneren en inzetbaarheid, opleiding en ontwikkeling. In 2014 is de steekproef vergroot van 80.000 naar 140.000 werknemers. De NEA is beschikbaar voor de jaren 2005-2019. De NEA wordt bekeken vanaf 2010, omdat in 2008 de vragen over het inzetten van maatregelen voor ouderen niet ingevuld waren.

5. Werkgeversenquête arbeid (WEA). De WEA is een enquête van TNO en CBS onder werkgevers met ten minste twee werknemers. De vragenlijst wordt jaarlijks ingevuld door 5.000 werkgevers. De vragenlijst bevat onder andere vragen over de maat- 
regelen die werkgevers nemen om werknemers inzetbaar te houden. De WEA is beschikbaar van 2008 tot en met 2016 en is sinds de laatste monitor niet geupdated. Derhalve laat deze rapportage geen nieuwe resultaten zien op basis van de WEA.

6. Zelfstandigen Enquête Arbeid (ZEA). De ZEA is een enquête van TNO en CBS onder zesduizend zelfstandig ondernemers over arbeidsomstandigheden en inzetbaarheid van zelfstandigen. De vragen komen deels overeen met de NEA-vragenlijst. De enquête is als pilot uitgevoerd in 2012 en daarna in 2015, 2017 en 2019. Deze enquête wordt elke twee jaar herhaald.

7. Gezondheidsenquête. De gezondheidsenquête is een enquête die inzicht geeft in de ontwikkelingen in de gezondheid, de medische contacten, de leefstijl en het preventieve gedrag van de bevolking in Nederland. De ondervraagde personen zijn o jaar en ouder die woonachtig in Nederland zijn. De gezondheidsenquête is van 2010 tot 2020 beschikbaar en wordt elk jaar herhaald.

8. Pensioenaanspraken Statistiek (PAS). Dit bestand bevat per persoon de hoogte van hun tweede-pijler pensioenaanspraak. PAS is beschikbaar voor 2015 en 2016.

9. GBAPERSOONTAB. Persoonskenmerken van alle in de GBA ingeschreven personen. GBAPERSOONTAB is gebruikt om de populatie te bepalen en hun leeftijd te bepalen. Voor dit onderzoek is gebruikgemaakt van de 2019-versie van het GBAPERSOONTAB.

10. GBAADRESOBJECTBUS. Adreskenmerken van personen die in de gemeentelijke bevolkingsregisters ingeschreven (hebben ge)staan. Door het GBAADRESOBJECTBUS te koppelen aan het GBAPERSOONTAB kan per jaar een selectie gemaakt worden van de personen die in Nederland woonachtig zijn. GBAADRESOBJECTBUS is beschikbaar voor de gehele periode (2007-2019). 


\section{Appendix D: Inhoud van de monitor}

De monitor bevat de volgende variabelen voor de periode 2007-2019:

\section{Wensen en mogelijkheden}

- Tot welke leeftijd (fysiek en geestelijk) kunnen werken (NEA/ZEA 55-65 jaar)

- Tot welke leeftijd willen doorwerken en verwachten door te kunnen werken (NEA/ ZEA 55-65 jaar)

\section{Intermediaire effecten (stromen)}

Stromen in en uit werk (CBS), op basis van belangrijkste inkomstenbron

- $\%$ uitstroom uit werk naar

- ZW/WIA

- WW

- Bijstand (uitsplitsen naar zelfstandigen en loondienst)

- Pensioen (uitsplitsen naar zelfstandigen en loondienst)

- Geen inkomen (uitsplitsen naar zelfstandigen en loondienst)

- $\%$ instroom in werk (vanuit bijstand, WW, WIA, ZW, geen inkomen)

- Gemiddelde pensioenleeftijd werknemers (leeftijd op basis van GBA)

\section{Intermediaire effecten (beleid op taakverlichting en taakuitbreiding)}

- (WEA) \% dat maatregelen voert op:

- Deeltijd vervroegde uittreding

- Oudere werknemers vrijstellen van onregelmatige en ploegendienst

- Kortere werkweek / aanpassing werktijden

- Extra vrije dagen oudere werknemers

- Stimuleren scholings- en cursusdeelname

- Taakverbreding/taakroulatie

- Taakverlichting en of aanpassingen takenpakket

- Loopbaan en functioneringsgesprekken

- Omscholen naar andere baan / functie

- Teruggang salaris / functie

- Aanpassen van de werkplek

- Gezondheidsbeleid

- Er zijn geen voorzieningen / maatregelen getroffen

-

- ...gemakkelijk een andere baan te kunnen vinden bij huidige werkgever

- ...gemakkelijk een andere baan te kunnen vinden bij een andere werkgever

- ....in de laatste 2 jaar van functie is veranderd 
- ...in de laatste 2 jaar een functie uitbreiding heeft gehad

- ...in de laatste 2 jaar een promotie heeft gemaakt

- ...in de laatste 2 jaar van een hogere naar een lagere functie is gegaan

\section{Verhogen inzetbaarheid werknemers}

- $\%$ werknemers dat in de afgelopen vier weken aangeeft een opleiding te volgen die minder dan 6 maanden duurt (EBB)

- Betaald door werkgever

- Betaald door werknemer

\section{Uitkomsten}

Arbeidsparticipatie

- Bevolking 55-75 jaar (Statline)

- Werkzame beroepsbevolking (EBB) (uitsplitsing naar zelfstandig/loondienst/beide)

Belangrijkste inkomstenbron (SECMBUS)

- Pensioen/AOW

- WIA/ZW

- WW

- Bijstand

- Overig inkomen: inkomen uit sociale voorziening en meewerkend gezinslid

- Geen inkomen

Inkomstenbron (SECMBUS) (iedereen met inkomen uit die bron, dus ook samenloop met andere inkomstenbronnen)

- Pensioen/AOW

- Waarvan samenloop met inkomen uit onderneming/loondienst

- WIA/ZW

- Waarvan samenloop met inkomen uit onderneming/loondienst

- WW

- Waarvan samenloop met inkomen uit onderneming/loondienst

- Bijstand

- Waarvan samenloop met inkomen uit onderneming/loondienst

- Geen inkomen

Hoogte inkomen (INPATAB)

- Gemiddeld persoonlijk bruto inkomen

Inzetbaarheid (NEA/ZEA 55-65 jaar)

- \% dat gemakkelijk kan voldoen aan fysieke eisen die het werk stelt

- \% dat gemakkelijk kan voldoen aan psychische eisen die het werk stelt

Gezondheid (Gezondheidsenquête) (vanaf 2010)

- Algemene gezondheid (5-puntsschaal) (vanaf 2010)

- Gezonde levensverwachting (Statline)

Alle reeksen zijn waar mogelijk uitgesplitst naar leeftijd, zodat de ontwikkelingen voor 65-jarigen apart in beeld konden worden gebracht. Indien dit niet mogelijk was zijn leef- 
tijdsklassen gehanteerd. Daarnaast zijn waar mogelijk per leeftijdsjaar of per leeftijdsklasse uitsplitsingen gemaakt naar opleidingsniveau (laag, middelbaar, hoog) of inkomensniveau (bruto persoonlijk inkomen).

Voor opleidingsniveau is data uit de betreffende enquête gebruikt waar toepasbaar (EBB, NEA, ZEA, Gecon). Voor de overige tabellen is opleidingsniveau afgeleid vanuit de koppeling met het opleidingsniveaubestand.

Daarbij zijn de volgende inkomensklassen gehanteerd:

1. negatief inkomen of een inkomen van nul

2. hoger dan nul en lager of gelijk aan het minimumloon

3. hoger dan minimumloon en lager of gelijk aan modaal

4. boven modaal tot twee keer modaal

5. meer dan twee keer modaal 
